\title{
МОЛОАТЖНА HAYKOBA
}

AII

\section{МАТЕРІАЛИ МЖКНАРОДНӦ̈ СТУДЕНТСЬКОÏ НАУКОВОÏ КОНФЕРЕНЦIÏ}

Конференцію схвалено УКРІНТЕЇ (Посвідчення №265 від 19.03.2020)

\section{7 КВІТНЯ 2020 \\ М. ХАРКIB, УКРАÏHA}

\section{НАУКА, ТЕХНОЛОГІї, IННОВАЦІЇ: ТЕНДЕНЦІЇ РОЗВИТКУ В УКРАÏHI ТА СВITI}




\section{МОАОАІЖНА HAYKOBA

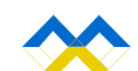

МАТЕРІАЛИ МІЖНАРОДНОЇ СТУДЕНТСЬКОÏ НАУКОВОÏ КОНФЕРЕНЦІї

17 КВІTНЯ 2020

М. ХАРКIB, УКРАÏHA

НАУКА, ТЕХНОЛОГIÏ, ІННОВАЦІЇ: ТЕНДЕНЦІЇ РОЗВИТКУ В УКРАÏНІ TA CBITI

\section{TOM 2}


Голова оргкомітету: Коренюк I.O.

Верстка: Дудник Г.М.

Дизайн: Бондаренко I.B.

Н 34 Наука, технології, інновації: тенденції розвитку в Україні та світі: матеріали міжнародної студентської наукової конференції (Т. 2), 17 квітня, 2020 рік. Харків, Україна: Молодіжна наукова ліга.

ISBN 978-617-7171-85-9

DOI 10.36074/17.04.2020.v2

Викладено матеріали учасників міжнародної мультидисциплінарної наукової конфреренції «Наука, технології, інновації: тенденції розвитку в Україні та світі», яка відбулася у місті Харків 17 квітня 2020 року.

Конференцію схвалено Державною науковою установою «УкрIHTEl» та зареєстровано в базі даних науково-технічних заходів України та інфрормаційному бюлетені «План проведення наукових, науково-технічних заходів в Україні» (Посвідчення № 265 від 19.03.2020).

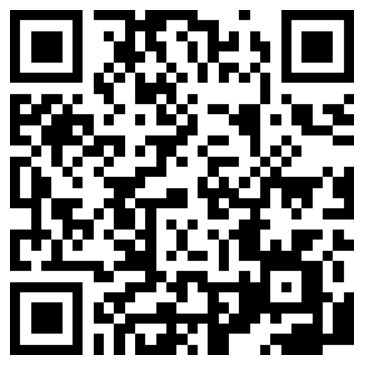

Матеріали конферениії знаходяться у відкритому доступі на умовах ліцензії Creative Commons Attribution 4.0 International (CC BY 4.0).

Всі роботи збірника, що містять DOІ індексуються - Google Scholar, ORCID, CrossRef ma OUCI (Український індекс наукового цитування).

УДК 001 (08) 


\section{СЕКЦІЯ 2.}

\section{MICT}

\section{ТЕХНІЧНІ НАУКИ ТА ІНФОРМАЦЙНІ ТЕХНОЛОГІЇ}

SQL INJECTIONS: TYPES AND DEFENSES

Hurieieva K. 6

WEB SCRAPING

Кравець А.M.

АЛГОРИТМ ОДНОРАЗОВОГО НАВЧАННЯ ДЛЯ РОЗПІЗНАВАННЯ ОБРАЗІВ (ONE-SHOT LEARNING)

Тимофсєва A.C. 8

ВИКОРИСТАННЯ ТЕХНОЛОГІЙ ВІРТУАЛЬНОГО ПРОЕКТУВАННЯ І КОНСТРУЮВАННЯ

Костюкова М.О., Галясовський В.І.

IННОВАЦІЙНІ SMART-ТЕХНОЛОГIÏ В УПРАВЛІННІ ГОТЕЛЬНИМ ГОСПОДАРСТВОМ

Геращенко О.В.

ІНТЕНСИФІКАЦІЯ БІОТЕХНОЛОГІЧНИХ ПРОЦЕСІВ ЗА ДОПОМОГОЮ УЛЬТРАЗВУКУ

Огороднічук I.O.

МОДЕРНИЗАЦИЯ ЭЛЕКТРОСЕТЕВОГО КОМПЛЕКСА ЗА СЧЕТ ВНЕДРЕНИЯ КОНЦЕПЦИИ «ЦИФРОВЫЕ СЕТИ»

Кустов А.Н., Деревнина В.С.

ОТРИМАННЯ ЕНЕРГІЇ ВІД СОНЦЯ

Дяченко В.С.

ПРИЛАД ДЛЯ АНАЛІЗУ ТА КОНТРОЛЮ МІКРОКЛІМАТУ В ТЕРАРІУМІ ДЛЯ РЕПТИЛІЙ

Довженко Б.I.

ПРИСТРІЙ ДЛЯ ПЕРЕВІРКИ СПРАВНОСТІ РОБОТИ ЕЛЕКТРОННИХ СИСТЕМ АВТОМОБІЛЯ

Острянко О.B.

ПРОБЛЕМИ ТА ПЕРСПЕКТИВИ ВИКОРИСТАННЯ ПРЯНО АРОМАТИЧНОЇ СИРОВИНИ В ТЕХНОЛОГІЯХ ХЛІБОБУЛОЧНИХ ВИРОБІВ

Драга А.Ю.

ПРОЕКТУВАННЯ ТЕХНОЛОГІЇ ФРУКТОВИХ ДЖЕМІВ ДЛЯ ПРОФІЛАКТИЧНОГО ХАРЧУВАННЯ

Чумак О.B.

РЕАЛИЗАЦИЯ СТРУКТУРЫ НЕЙРОННЫХ СЕТЕЙ НА FРGА

Чумак B.C. 
РОЗРОБКА ПРИЛАДУ КЕРУВАННЯ ОСВІТЛЕННЯМ В ПРИМІЩЕННЯХ

Салім М.С.

ШЛЯХИ ОПТИМІЗАЦІЇ РОЗПОДІЛЬНИХ МЕРЕЖ ЗА РЕАКТИВНОЮ ПОТУЖНІСТЮ

Буславець Д.О.

СЕКЦІЯ 3.

ФІЗИКО-МАТЕМАТИЧНІ НАУКИ

КОСМІЧНІ ПРОМЕНІ В ЖИТТІ ЛЮДЕЙ

Кирпель П.С. 38

МАТЕМАТИЧНЕ МОДЕЛЮВАННЯ

Скібчик С.А. 41

СОНЯЧНІ ЕЛЕМЕНТИ

Куценко Т.Я. 42

\section{СЕКЦЯ 4.}

ХІМІЧНІ НАУКИ

ЛАБОРАТОРНО-ХІМІЧНА ЕКСПЕРТИЗА ЯКОСТІ ПАСТЕРИЗОВАНОГО КОРОВ'ЯЧОГО ПИТНОГО МОЛОКА

Образенко А.Ф.

\section{СЕКЦІЯ 5.}

\section{БІОЛОГІЧНІ НАУКИ}

БАКТЕРІЇ ЕНДОФІТНОГО СЕРЕДОВИЩА ПУХЛИН ВИНОГРАДУ ОДЕСЬКОЇ ОБЛАСТІ ТА ЇХ БІОЛОГІЧНІ ВЛАСТИВОСТІ

Сороколат I.C.

ІДЕНТИФІКАЦІЯ ІЗОЛЯТУ ФІТОПАТОГЕННИХ БАКТЕРІЙ, ВИДІЛЕНОГО 3 УРАЖЕНОГО ЛИСТЯ ГІРКОКАШТАНУ ЗВИЧАЙНОГО (АЕSCULUS HIPPOCASTANUM L.)

Додон Д.С.

ФИНАНСИРОВАНИЕ БИОТЕХНОЛОГИЧЕСКИХ ЛАБОРАТОРИЙ КАК СПОСОБ ПОВЫШЕНИЯ ИХ ЭНЕРГОЭФФЕКТИВНОСТИ

Мудренко М.А.

\section{СЕКЦІЯ 6. МЕДИЧНІ НАУКИ}

FEATURES OF ARTERIAL HYPERTENSION IN PATIENTS WITH HYPOTHYROIDISM

Nahornyi I. 
ВИВЧЕННЯ ПРОБЛЕМ РЕПРОДУКТИВНОГО ЗДОРОВ'Я СУЧАСНОЇ МОЛОДІ

Стоян А.O.

ВПЛИВ ЗОВНІШНІХ ФАКТОРІВ НА РОЗВИТОК ЗАГОСТРЕНЬ БРОНХІАЛЬНОЇ АСТМИ

Гуманець К.P., Марченко I.O.

ВПЛИВ ЦУКРОВОГО ДІАБЕТУ НА ПРОГНОЗ ЩОДО ВИЖИВАННЯ ПАЦІЕНТІВ ІЗ РАКОМ ПРЯМОЇ КИШКИ

Остапенко Д.М.

ЕМОЦІЙНИЙ ІНТЕЛЕКТ ЯК ПЕРЕДУМОВА ДО ПЕРВИННОЇ ПРОФІЛАКТИКИ АРТЕРІАЛЬНОЇ ГІПЕРТЕНЗІЇ У ПІДЛІТКІВ

Копитько Н.С.

МЕТАБОЛІЧНИЙ СИНДРОМ - ПРОБЛЕМА ХХІ СТОЛІТТЯ

Лигирда О.В., Немеш I.M.

ПЕРЕВАГИ ВИКОРИСТАННЯ ГЛІКЕМІЧНОГО ІНДЕКСУ ДЛЯ СКЛАДАННЯ ДІЄТ У ПОРІВНЯННІ 3 КАЛОРІЙНІСТЮ ЇЖІ

Мимренко А.А., Кузьмак М.В.

ПРИХИЛЬНІСТЬ ДО ЛІКУВАННЯ ПІДЛІТКІВ 3 ЦУКРОВИМ ДІАБЕТОМ І ТИПУ

Кирилова С.І., Вострокнутов І.Л.

ПРОБЛЕМИ ДОКАЗОВОЇ МЕДИЦИНИ В УКРАЇНІ

Пелих I.М.

РЕТРОСПЕКТИВНИЙ АНАЛІЗ ПРИЧИН КЕТОАЦИДОЗУ У ХВОРИХ НА ІНСУЛІНОЗАЛЕЖНИЙ ЦУКРОВИЙ ДІАБЕТ У СТАДІЇ ДЕКОМПЕНСАЦІЇ

Гордієнко П.О.

ТЕНДЕНЦІЯ РОСТУ ПРОФЕСІЙНОГО ЗАХВОРЮВАННЯ СЕРЕД ПРАЦІВНИКІВ ХАРКІВСЬКОГО ТРАКТОРНОГО ЗАВОДУ

Бадалов 3.А.

ФІБРОМІАЛГІЯ

Анкутова А..В, Атаi С. Г. 


\section{СЕКЦІЯ 2.}

\section{ТЕХНІЧНІ НАУКИ ТА ІНФОРМАЦІЙНІ ТЕХНОЛОГІї}

Kateryna Hurieieva, applicant for master degree, faculty of mathematics Zaporizhzhia National University, Ukraine

\section{SQL INJECTIONS: TYPES AND DEFENSES}

A SQL injection is one of the most common ways of attacking websites or programmes that work with databases. It consists of insertion or "injection" of a SQL query via the input data from the client to the application. A successful SQL injection exploit can read, modify or delete sensitive data from the database, execute administration operations on the database. This type of attack is well known and widely used since the days when websites or software began to work with databases. And till now it is considered as one of the most dangerous.

There are several types of SQL injections: error based, union based or blind(partblind and full-blind) based injections.

Error based injections are exploited through triggering errors in the database when invalid input are passed to it. The error messages can be used to return the full query results, or gain information on how to restructure the query for furhter information.

Union based injections allows to extract information from the database by extending the results returned by the original query.

In blind SQL injection no data is actually transferred via the application and the attacker would not be able to see the result of an attack. Instead an attacker is able to recostruct the database structure by observing the application response and the resulting behaviour of the database server.

Part-blind SQL injection rellies on sending a SQL query to the database which forces the application to return a different result depending on whether the query returns a true or false result.

Full-blind injections relies on sending SQL query to the database which forces it to wait for a specified amount of time before responding. The response time will indicate to the attacker whether the result of the query is true or false. Depending on the result a response will be returned with a delay or immediately.

To prevent a SQL injection following defense techniques can be used.

Firstly, the use of prepared statements with variable binding is the easiest way to make your SQL queries more secure. Parameterized queries force the developer to first define all the SQL code, and then pass in each parameter to the query later. This coding style allows the database to distinguish between code and data, regardless of what user input is supplied.

Various parts of SQL queries are not legal locations for the use of bind variables, such as the names of the tables or columns, and the sort indicator. In such situations, input validation or query redesign is the most appropriate defense. For the names of tables or columns, ideally those values come from the code, and not from user parameters. But if user parameter values are used to make different for table names and columns names, then the parameter values should be mapped to the legal/expected table or column names to make sure unvalidated user input does not end up in the query.

Although, SQL injections are still dangerous for applications that work with databases, a lot of defensive techniques are developed and implemented so sooner or later this type of attacks will be compeletely forgotten. 
References:

1. NetSPI SQL Injection Wiki [Електронний pecypc] - Режим доступу до ресурсу: https://sqlwiki.netspi.com/.

2. SQL Injection [Електронний pecypc] - Режим доступу до ресурсу: https://www.owasp.org/index.php/SQL_Injection.

3. Types of SQL Injection [Електронний pecypc] - Режим доступу до ресурсу: https://www.acunetix.com/websitesecurity/sql-injection2/.

4. Blind SQL Injection: What is it? [Електронний ресурс] - Режим доступу до ресурсу: https://www.acunetix.com/websitesecurity/blind-sql-injection/.

5. SQL Injection Prevention Cheat Sheet [Електронний ресурс] - Режим доступу до ресурсу: https://www.owasp.org/index.php/SQL_Injection_Prevention_Cheat_Sheet.

Кравець Анастасія Михайлівна, здобувач вищої освіти кафедри обчислювальної техніки Національний технічний університет Украйни "Киїський політехнічний інститут імені Ігоря Сікорського”, Україна

Науковий керівник: Шевченко Ольга Миколаївна, старший викладач кафедри англійської мови гуманітарного спрямування №3 ФЛ,

Національний технічний університет Украӥни “Київький політехнічний інститут імені Ігоря Сікорського”, Украӥна

\section{WEB SCRAPING}

A web resource becomes valuable and visited only if it has useful, interesting and unique content. In order to succeed in nowadays frequently changing world, it is very important to receive up-to-date data on market movements (price, popularity and other metrics) and local news, which sometimes strongly affect demand formation.

Nowadays, the amount of information exceeds the limits of its manual processing time, so that even the most talented person is not efficient any more. Therefore, scraping (also called parsing) was invented for the automatic collection and processing of large amounts of information. Objectives. Commonly speaking, web scraping is the collection of data from various Internet resources [2].

Web scraping is essentially a form of data mining. Items like weather reports, auction details, market pricing, or any other list of collected data can be sought in Web scraping efforts. The practice of Web scraping has drawn a lot of controversy because the terms of use for some websites do not allow certain kinds of data mining. Despite the legal challenges, Web scraping promises to become a popular way of collecting information as these kinds of aggregated data resources become more capable.

The general principle of this process can be explained as follows: a certain automated code executes GET requests to the target site and receives a response, parses an HTML document, searches for data and converts it into a given format. The useful data category may include catalogues, images, video, text content, open contact details email addresses, phone numbers, etc.

There are many tools to extract data from websites without writing a single line of code. Tools can be stand-alone applications, websites, or browser plug-ins. Before writing own web scraper, it is better to study the existing tools.

In general, many of such scrapers have very good video tutorials explaining how it all works. The first thing that novice "scrappers" should deal with is the Document Object Model. Any HTML-document is built with object model: elements are arranged in a tree 
hierarchy. Each HTML tag becomes part of the tree with the type "element". The tags that are embedded become child nodes. Each element has an attribute - characteristic. Using a DOM application and scraping code, the computer can "see" the content of HTML pages. By specifying the element you are looking for and its characteristics, you can automatically find it on many web pages without using a manual search [1].

Results. It is safe to say that web scraping has become an essential skill to acquire in today's digital world, not only for tech companies and not only for technical positions. The greatest success of using this approach is that your data is always up-to-date. Moreover, you can profit from such technology - studying the demands of the market and satisfying them can enlarge your revenue. It is easier to find the mistakes of business strategy and fix them. Such a big set of parsed and organized data can be easily reused and maintained. Conclusion. To sum up, there are many interesting methods of analysis and data collection. Web scraping is an easy way to learn how to make the content better and increase conversion.

\section{References:}

1. Glez-Peña, D., Lourenço, A., López-Fernández, H., Reboiro- Jato, M., \&amp; Fdez-Riverola, F. (2013). Web scraping technologies in an API world. Briefings in bioinformatics, 15(5), 788-797.

2. Vargiu, E., \&amp; Urru, M. (2013). Exploiting web scraping in a collaborative filtering-based approach to web advertising. Artif. Intell. Research, 2(1), 44-54.

Тимофєєва Анастасія Свгенівна, здобувач вищої освіти математичного факультету Запорізький національний університет, Україна

\section{АЛГОРИТМ ОДНОРАЗОВОГО НАВЧАННЯ ДЛЯ РОЗПІЗНАВАННЯ ОБРАЗІВ (ONE-SHOT LEARNING)}

Основна ідея алгоритму полягає в наступному: зображення-зразок має бути структуровано, тобто інформація в ньому повинна бути зменшена до необхідного мінімуму, але так щоб не втрачався сенс. Фотографія містить матрицю $\mathrm{N} * \mathrm{M}$ пікселів кожен піксель містить скільки-то біт інформації про колір, а якщо уявити це все у вигляді параметрів ліній то обсяг інформації різко зменшується і обробка такої інформації стає набагато простіше, тобто, алгоритм повинен виділити головні деталі в кадрі - те, що несе в собі основну інформацію і відкинути все зайве.

Для того щоб отримати вектори, зображення проходить кілька стадій обробки:

1. Переведення в монохром за простою формулою $($ Red + Green + Blue $) / 3$;

2. Обчислення градієнту для кожної точки матриці;

3. Знаходження найбільш значущої у ваговому відношенні області градієнта;

4. Знаходження ланцюжка векторів, що покривають ці області;

5. Зациклення кроків для отримання в результаті мінімальної кількості векторів, що несуть в собі максимум інформації.

Сама класифікація побудована за принципом пошуку найбільш схожого зображення зі збережених. Найбільш схоже - це те, що має найбільшу кількість співпадаючих векторів з найменшими відхиленнями по відношенню до загального обсягу векторів у зразку.

Не дивлячись на те, що алгоритм може ефективно працювати з одного зразка, $\epsilon$ можливість підвищувати точність розпізнавання, аналізуючи кілька зразків. Принцип навчання на декількох зразках полягає у відкиданні зайвих векторів. Зайві 
- це ті, які не ввійшли у взаємно знайдений кластер векторів. Наприклад, на зразку може бути тінь, яка розпізнається як межа, а на наступному зразку їі може не бути.

Переваги перед нейронними мережами:

1. Не потрібні великі датасети для навчання;

2. Не потребує великої потужності та часу для навчання кожного зображення;

3. Відсутність непрозорості алгоритму та неможливості налагодження й прямого впливу на результат.

\section{Список використаних джерел:}

1. One-Shot Learning [Електронний pecypc] - Режим доступу до ресурсу: https://medium.com/@connorshorten300/one-shot-learning-70bd78da4120;

2. Data Science-дайджест №10: полезные статьи для аналитиков [Електронний ресурс] - Режим доступу до ресурсу: https://netology.ru/blog/09-2019-data-science-daydjest-10;

DOI 10.36074/17.04.2020.v2.01

Костюкова Марія Олександрівна, здобувач вищої освіти будівельного факультету «Придніпровська державна академія будівництва та архітектури», Україна

Галясовський Владислав Іванович, здобувач вищої освіти будівельного факультету «Придніпровська державна академія будівництва та архітектури», Україна

\section{ВИКОРИСТАННЯ ТЕХНОЛОГІЙ ВІРТУАЛЬНОГО ПРОЕКТУВАННЯ І КОНСТРУЮВАННЯ}

Постійне зростання складності цифрових систем зробила революцію в тому, як професіонали в секторах AEC (архітектури, проектування та будівництва) планують, керують і реалізують свої будівельні або інфраструктурні проекти. Хоча системи автоматизованого проектування i розрахунку (САПР) в даний час $\epsilon$ важливим інструментом в процесі проектування, BIM забезпечує більш широке управління протягом усього життєвого циклу проекту, зокрема, шляхом генерації повних і доступних даних, що стосуються структури, яка знаходиться в процесі розробки будівництва.

VDC, або віртуальне проектування і конструювання, являє собою процес, який використовує інтегрований міждисциплінарний підхід для створення моделей продуктивності для проектів проектування і виробництва. Сфери застосування i концепції реалізації САПР, BIM і VDC частково збігаються. Багато команд 3 сектора АЕС об'єднують доступні їм інструменти й процеси за допомогою цілісного підходу до проектування та управління будівлями та інфраструктурою.

Цей процес є віртуальним, оскільки він включає комп'ютерне моделювання, але те ж саме можна сказати й про CAD i BIM. BIM також може надати міждисциплінарну модель проекту для підтримки бізнес-цілей. Таким чином, ці два процеси дуже часто порівнюють.

Дійсно, в той час як ВIM збирає різну інформацію, що стосується будівель або споруд, від їх проектування до знесення, VDC швидше стосується етапів проектування та будівництва проекту.

3 іншого боку, VDC йде набагато далі, ніж CAD, і його також можна описати як процес моделювання «5D», в який включені час і витрати. Це дозволяє моделям виступати в якості моделей продуктивності й моделей проектування, оскільки вони 
можуть не тільки прогнозувати, але і вимірювати багато аспектів ефективності проекту в міру їх виникнення.

Процес віртуального проектування і конструювання настільки великий, що охоплює весь життєвий цикл конструкції. Між віртуальним проектуванням i конструюванням встановлюються прямі зв'язки, які гарантують, що фізична побудова проекту відповідає своєму цифровому двійникові. VDC в основному охоплює перехід від цифрового до фізичного, а потім від фізичного до цифрового.

Віртуальне конструювання стосується таких етапів розробки проектів:

- 3D модулювання

- цифрування результатів

- перевірка інформації моделі

- моделювання хмар точок

Разом з CAD і BIM, VCD дозволяє отримувати такі результати проектування:

- параметричне моделювання;

- побудова моделювання даних;

- комплексна реалізація проекту;

- 2D та 3D-моделювання на підтримку дизайну;

- валідація або перегляд дизайну;

- 4D моделювання;

- аналізи та дослідження конструктивності;

- багатодисциплінарний робочий процес у спільному режимі;

- моделювання та аналіз продуктивності;

- енергетичне моделювання та аналіз;

- інтеграція аналізу ризиків;

- автоматизація будівництва.

VDC також дозволяє професіоналам в секторі AEC моделювати інші виміри, а саме час і гроші, одночасно полегшуючи прогнозування та вимірювання елементів ефективності.

Таким чином, можливе моделювати проекти практично з нуля, щоб отримати реалістичне уявлення про будівлі та споруди, а також про витрати, час i трудовитрати, що дозволяє ефективний розвиток проекту ще до початку будівельного процесу.

Геращенко Олеся Володимирівна, викладач кафедри харчових технологій Київський кооперативний інститут бізнесу і права, Украӥна

\section{IННОВАЦІЙНІ SМАRТ-ТЕХНОЛОГІЇ В УПРАВЛІННІ ГОТЕЛЬНИМ ГОСПОДАРСТВОМ}

Одне 3 найбільш важливих завдань, що стоїть перед готельними господарствами - це отримати найбільше клієнтів та зробити їх постійними відвідувачами. Виконати це завдання допоможуть інноваційні технології, які істотно поліпшують умови роботи готелю.

Інноваційна діяльність в сфері готельного бізнесу досить специфічна, направлена, передусім, на задоволення вимог клієнтів, забезпечення якості обслуговування, підвищення економічної ефективності. В силу інформаційної доступності та відкритості сучасних підприємств сфери готельних послуг інновації в готельному бізнесі досить швидко копіюються та розповсюджуються, і як наслідок 
втрачають свою актуальність. Тому готельні підприємства постійно повинні застосовувати інноваційні підходи [3].

На сьогоднішній день одними 3 найбільш сучасних інноваційних інформаційних технологій є Smart - технології [2].

Smart - технології - це сучасний підхід до постановки і формування цілей, який дозволяє на початковому етапі узагальнити всю наявну інформацію, позначити прийнятні терміни роботи, а також надати всім учасникам ясні та конкретні задачі. Smart - технології є одними з найкращих інноваційних рішень при управлінні готелем.

Найбільш поширеним універсальним продуктом для готелів є технології JUNG, що сприяють енергоефективності процесів та раціональному використанню ресурсів. Дана система дозволяє об'єднати програмне забезпечення та готельне обладнання в єдину систему, що сприяє ефективному плануванню робочого часу персоналу та забезпечує кращий сервіс для гостя.

Інноваційна інтелектуальна система управління готелем WeHotel розроблена на основі новітніх технологій IОТ. Вона контролює пристрої локально і віддалено, оптимізує процеси і економить електроенергію, знижує загальні затрати на управління готелем та експлуатацію всіх систем.

Перший повністю автоматизований готель відкрився в китайському місті Ченду. Smart LYZ - це ідеальне місце для тих, хто не хоче спілкуватися з персоналом: тут ви не зустрінете охоронців, адміністраторів і покоївок. Всі їх функції “беруть на себе" автоматизовані системи [4].

I хоча на вході немає жодного security, рівень безпеки в готелі не підлягає сумнівам: двері відкриваються тільки після того, як мандрівник проходить систему верифікації через номер свого мобільного телефону, тобто потрапити всередину можуть тільки постояльці готелю [4].

У вестибюлі Smart LYZ відсутні стійка реєстрації: особисті дані гостя перевіряє робот і потім проводжає його в номер. Всі побажання мандрівників теж виконують роботи, наприклад, доставляють в кімнату їжу і проводять прибирання номера [4].

В управлінні готелем набувають популярності німецькі технології REHAU. Вони дозволяють зробити готель привабливим для гостей і підтримують його в первозданому стані в період довгого часу. Пристрої цього бренду призначені для автоматизації роботи системи і обслуговування постійного комфорту в режимі 24/7 і 365 днів в році. Зниження витрат при експлуатації і будівництві готелів являються ключовими напрямами в роботі REHAU. Енергоефективне будівництво можливе при використанні матеріалів високої якості і сучасних технологій. Своєчасна діагностика, офіціальна гарантія i правильний догляд за системами життєзабезпечення готелю дозволяє повністю розкрити потенціал німецької бездоганності і надійності.

Необхідність застосування і впровадження на вітчизняних підприємствах готельно-ресторанного бізнесу новітніх моделей управління 3 допомогою комп'ютерних систем і технологій, які відповідають світовим стандартам, обумовлена прагненням надати гостям найякісніші послуги, забезпечивши їх комфорт і безпеку [1].

Висновки. Таким чином, вплив інформаційних Smart - технології на управління готельним господарством досить великий адже прямо пов'язаний 3 підвищенням ефективності роботи як кожного менеджера, так і готелю в цілому.

\section{Список використаних джерел:}

1. Перепилиця А. С. (2017) Інформаційні технології в управлінні піприємствами готельноресторанного бізнесу. ХНУ імені В.Н. Каразина, 251-266. Вилучено з: http://dspase.univer.kharkov.ua/handle/123456789/13343. 
2. Твердохліб А.І. (2017) Смарт-технології як основа формування сучасних тенденцій освіти. Вісник Університету імені Альфреда Нобеля, (1), 301-305. Вилучено з: http://nbuv.gov.ua/UJRN/vduep_2017_1_49.

3. Тімар I.В. (2015) Інноваційна складова іміджу підприємств сфери готельних послуг. Видавнищтво львівської політехніки, 355-356. Вилучено 3: http://ena.lp.edu.ua/bitstream/ntb/32300/1/197.pdf

4. У Китаї відкрився готель без персоналу [Електронний ресурс] - Режим доступу до ресурсу: https://bytsko.com/u-kita---v--dkrivsya-gotel-bez-personalu/

Огороднічук Інна Олександрівна, аспірантка

Вінницький національний аграрний університет, Україна

\section{ІНТЕНСИФІКАЦІЯ БІОТЕХНОЛОГІЧНИХ ПРОЦЕСІВ ЗА ДОПОМОГОЮ УЛЬТРАЗВУКУ}

Ультразвук - це галузь, що швидко розвивається, яка знаходять все більш широке використання в харчовій промисловості для аналізу, переробки, модифікації та збереження харчових продуктів. Дослідження за останнє десятиліття показали потенційні переваги ультразвукового опромінення як альтернативної нетермічної технології переробки їжі. Ультразвукова обробка ще знаходиться в початковому стані і вимагає великої кількості майбутніх досліджень для розвитку технології в промислових масштабах. Характеризується ультразвукова дія наявністю пружних коливань і хвиль частотою вище 18 - 20 кГц, які і визначають його специфічні особливості в різних середовищах.

Застосування біотехнологічних процесів у харчовій промисловості досить широке, передбачає використання живих організмів та біологічних процесів у промисловому виробництві. При цьому сучасні тенденції в області харчової індустрії обумовлюють доцільність вдосконалення технологій в напрямку мінімізації енергетичних та матеріальних ресурсів. Поряд 3 різними відомими методами обробки, останнім часом, значне місце займають використання фізичних методів, зокрема, імпульсного ультразвукового впливу.

Ультразвукові технології, що інтенсивно розвиваються мають значний вплив на біологічні об'єкти. Низка суттєвих переваг, щодо використання, обумовлена сукупністю специфічних ефектів, які чинять комплексний вплив направлений на інтенсифікацію процесу. Використання ультразвукових коливань малої інтенсивності викликає позитивні біологічні ефекти, зокрема, у бактерій та дріжджів підвищується ефективність використання поживних речовин, прискорення процесів метаболізму та отримання продуктів з новими властивостями. Тоді як хвилі великої інтенсивності спричиняють незворотні пошкодження клітини. При цьому направленість впливу визначається вимогами технологічного процесу, властивостями оброблюваного середовища та параметрами ультразвукового впливу.

Тому дослідження і розробка високоефективної енергозберігаючої та екологічно чистої технології для інтенсифікації біотехнологічних процесів на основі застосування ультразвукових коливань $є$ актуальним та перспективним напрямком. Ультразвукові коливання можуть застосовуватися для ініціювання хімічних реакцій, здійснення ряду нових методів синтезу і прискорення повільних реакцій в органічній системі. Ультразвукова дія здатна сповільнювати ріст і поділ клітин, що сповільнює життєдіяльність і розвиток популяції.

\section{Список використаних джерел:}

1. Акопян В.Б., Ершов Ю.А. Основы взаимодействия ультразвука с биологическим объектами. М.: МГТУ им. Н. Э. Баумана, 2005. - 224 с. 
2. Берник I.M. Інтенсифікація технологічних процесів обробки харчових середовищ / I.M. Берник // Вібрації в техніці та технологіях. - 2013. - № 3. - С. $109-115$.

3. Луговской А.Ф. Ультразвуковая кавитация в современных технологиях / А. Ф.Луговской, Н. В. Чухраев. - К.: Видавничо-поліграфічний центр “Київський університет”, 2007.-244 с. : ил., табл. - Библиогр.: с. 229-243. - ISBN 966-594-927-6.

4. Педдер, В.В. «Обратный» ультразвуковой капиллярный эффект и некоторые направления его клинического применения / В.В. Педдер, А.В. Педдер, В.В. Хмелев и др. // Х-я международная конференция-семинар EDM 2009, 1-6 июля, Эрлагол. Новосибирск.- Изд-во Новосибирского государственного технического ун-та. 2009.-С 414-423.

5. Полєвода Ю.А. Перспективи застосування вібраційних ефектів в рідких технологічних системах харчових і переробних виробництв / Ю.А. Полєвода // Технічні науки. — 2015. — № 1. — С. 124 -130 .

Кустов Александр Николаевич, магистрант

Липецкий государственный технический университет, Российская Федерация

Деревнина Виктория Сергеевна, студентка 2 курса

Липецкий государственный технический университет, Российская Федерация

\section{МОДЕРНИЗАЦИЯ ЭЛЕКТРОСЕТЕВОГО КОМПЛЕКСА ЗА СЧЕТ ВНЕДРЕНИЯ КОНЦЕПЦИИ «ЦИФРОВЫЕ СЕТИ»}

Обеспечение качественного [1] и бесперебойного электроснабжения является одной из главных функций территориальных сетевых организаций (ТCO). В настоящее время в связи с высокой степенью изношенности (около 70\%) распределительного сетевого комплекса вопрос нормативного электроснабжения потребителей встает очень остро.

Приведем краткую характеристику нынешнего состояния дел на примере одного из ТСО Центрального федерального округа, входящего в состав ПАО «Россети».

Статистика аварийных отключений и повреждаемости распределительных сетей за 2017 г. говорит о том, что наибольшая часть повреждений (62\%) связана с междуфазными и однофазными замыканиями вследствие выпадения деревьев из лесных массивов, падения веток.

Далее идут повреждения, связанные с межфазными замыканиями в результате перехлеста фаз по причине недопустимых стрел провиса, налипания мокрого снега, обрыва проводов $(22 \%)$, повреждения коммутационной аппаратуры $(9 \%)$, постороннего воздействия в виде несанкционированной валки деревьев в охранной зоне ЛЭП, умышленной порчи оборудования (7\%).

По характеру повреждений распределение таково: 45\% - двухфазные К3, 32\% - однофазные замыкания на землю, 15\% - трехфазные КЗ, $8 \%$ - прочие виды (обрывы, двухфазные КЗ с замыканием через землю).

Результаты анализа повреждаемости говорят о том, что в большинстве случаев для скорейшего восстановления повреждения требуется: локализация поврежденного участка ЛЭП, перевод неповрежденных участков на резервное питание, восстановление поврежденного участка, возврат к нормальной схеме электроснабжения.

Опыт зарубежных стран показывает, что стремительное внедрение информационных технологий в различных отраслях при определенных условиях 
дает большой толчок к развитию этой отрасли.

В частности, электросетевые операторы Западной Европы, входящие в ENSTO-E (Франция, Испания, Германия, Бельгия, Нидерланды), планируют в период с 2017 г. по 2030 г. осуществить инвестирование в электросетевое хозяйство на уровне 1 триллиона евро. При этом значительная часть средств направлена на информатизацию и цифровизацию сетей, в том числе и с целью повышения показателей надежности. Все чаще звучит словосочетание «smartgrid».

Опираясь на опыт зарубежных коллег, одним из основных решений повышения надежности распределительной сети видится внедрение в электросетевой комплекс концепции «цифровых сетей» $[2,3,4]$.

Цифровая сеть - совокупность объектов электросетевого комплекса, ключевыми факторами эффективного управления которым являются данные в цифровом виде, обработка больших объемов, использование результатов анализа которых позволяет существенно повысить эффективность деятельности электросетевых компаний, доступность и качество их услуг для потребителей.

Цифровая сеть соответствует критериям:

- наблюдаемость параметров системы и режима работы всех элементов электросетевого комплекса;

- интеллектуальный учет электроэнергии;

- интеллектуальное, адаптивное управление режимом работы электросетевого оборудования с учетом режимов потребления электрической энергии;

- самодиагностика и способность к самовосстановлению после сбоев в работе отдельных элементов;

- управляемость электросетевого комплекса в режиме реального времени посредствам цифровых систем связи и оборудования, обеспечивающего поддержку протоколов, утвержденных стандартом МЭК.

Основные принципы цифровизации для повышения надежности:

- передача данных от приборов учета электроэнергии (напряжение, ток, мощность и др.) в ПТК для осуществления оперативно-технологического управления процессами функционирования электрических сетей;

- телеуправление коммутационными аппаратами РП 6-20 кВ (при наличии технической возможности);

- организация системы переменного (выпрямленного) оперативного тока на РП 6-20 кВ для питания вторичных систем и цепей управления коммутационными аппаратами без применения аккумуляторных батарей;

- изменение топологии (реконфигурация и «закольцовка») сети для реализации функций автоматического выделения поврежденного участка, самовосстановления сети, посредством установки секционирующих управляемых коммутационных аппаратов, установки цифровых указателей направления токов КЗ;

- алгоритмизация устранения повреждений в цифровых сетях.

На данном этапе, на примере рассматриваемой ТСО уже имеется положительный опыт применения элементов цифровой (или «умной») сети.

Так, на базе Района Электрических Сетей №1 (РЭС №1) в начале 2017 г. был выполнен комплекс работ по монтажу и пуско-наладке реклоузера (BB-TEL). Был проведен анализ часто отключаемых фидеров 6-10 кВ. Выбран наиболее отключаемый фидер с двойным питанием и с большим отпуском электроэнергии, от которого питаются социально-значимые объекты. Точка потокораздела была выбрана таким образом, что в нормальном режиме обеспечивался оптимальный режим работ, а в послеаварийном сохранялась возможность перевода социально- 
значимых объектов на резервное питание. Телеуправление реклоузером было выведено на автоматизированное рабочее место диспетчера РЭС №1 [5, 6].

Таким образом, было достигнуто снижение времени перерыва электроснабжения на 69\% по сравнению с аналогичным периодом за 2016 г.

Распространение таких технических решений упрощает работу дежурного диспетчера РЭС и позволяет снизить ущерб от аварийных отключений потребителей, уменьшить трудовые затраты на нахождение и ликвидацию возникающих повреждений и затраты на работы, связанные с проведением испытаний средств защиты и автоматики.

Технический эффект от внедрения реклоузеров: снижение частоты повреждений линии; уменьшение времени восстановления электроснабжения; снижение времени поиска и локализации повреждения на линии; снижение числа ремонтных работ на линии; отказ от разукрупняющих подстанционной РЗиА и маломасленных выключателей.

Экономический эффект от внедрения рекроузера:

- снижение возможного искового требования к энергоснабжающей организации или прямого ущерба собственника сети;

- снижение затрат на обслуживание линейного оборудования;

Внедрение реклоузеров в электросетевой комплекс позволит нам создать управляемую (автономную) интеллектуальную сеть, которая:

- будет вести сбор, обработку и запись информации о событиях и об изменениях работы;

- повысит надежность системы за счет ее мониторинга с целью поиска и определения неисправностей;

- упростит профилактическое обслуживание линейного сетевого оборудования.

В итоге, внедрение комплекса мер по увеличению надежности электроснабжения потребителей распределительных сетей нужно проводить индивидуально для каждой ТСО, с учетом особенностей схем, методов резервирования, расположения, степени существующей автоматизации, мощности и характеристик потребителей $[7,8]$.

Таким образом, применяя реклоузеры в электросетевом комплексе как часть «цифровой сети», мы создаем технологию оптимального управления энегосистемами, которая которая требует дальнейшего развития и внедрения.

\section{Список использованных источников:}

1. ГОСТ 32144-2013. Нормы качества электрической энергии в системах электроснабжения общего назначения. - Новосибирск: Сиб. унив. изд-во, 2014. - 20 с.

2. Phadke A.G., Thorp J.S. Computer relaying for power systems Second Edition, Research Studies Press Ltd. New York: John Wiley \& Sons, Inc., 2009. - 362 p.

3. European Network of Transmission System Operators for Electricity (ENTSO-E), Retrieved from http://entsoe.eu.

4. European Commission, European Smart Grids Technology Platform - Vision and Strategy for Europe's Electricity Networks of the Future, 2006. Available online Retrieved from http://ec.europa.eu/research/energy/pdf/smartgrids_en.pdf.

5. Kustov A. (2019, November 29). Modern potential and economic opportunities of managing alternative energy sources. Sur les matériaux de la conférence scientifique et pratique internationale «Problèmes et perspectives d'introduction de la recherche scientifique innovante». Bruxelles, Belgique. - 2019. - Vol. 2. - P. 82-87.

6. Васильева, Т.Н. Надежность электрооборудования и систем электроснабжения. - Москва: Горячая линия - Телеком, 2015. - 152 с.

7. Анашкин, С.С. Способы повышения надежности электроснабжения потребителей в сельской местности. Молодой ученый. - 2018. - № 3. - С. 34-36. 
8. Кустов А.Н., Шпиганович А.А. (2019) Современный потенциал и перспективы развития возобновляемой энергетики. Современные проблемы электроэнергетики и пути их решения: материалы V Всероссийской научно-технической конференции. - Махачкала: ДГТУ, 2019. $209 \mathrm{c}$.

Дяченко Владислав Сергійович, здобувач молодшого спеціаліста

Лозівська філія Харківського державного автомобільно-дорожнього коледжу, Україна

\section{Наукові керівники:}

Капустіна Таміла Петрівна, викладач вищої категорії

Лозівська філія Харківського державного автомобільно-дорожнього коледжу, Україна

Шарий Віктор Володимирович, викладач вищої категорії

Лозівська філія Харківського державного автомобільно-дорожнього коледжу, Україна

\section{ОТРИМАННЯ ЕНЕРГІЇ ВІД СОНЦЯ}

Джерелом енергії сонячного випромінювання служить термоядерна реакція кожну секунду на сонці приблизно $6 \cdot 10^{11}$ кг водню перетворюється в гелій. При цьому Сонце зменшується на $\mathrm{G}=4000 \kappa г / \mathrm{c}$, що, згідно 3 формулою Ейнштейна, призводить до виділення енергії $\mathrm{Q}=\mathrm{Gc}^{2}=4 \cdot 10^{20}$ Дж/с, де с - швидкість світла. (Повна маса Сонця $2 \cdot 10^{30}$ кг). При цьому в напрямку Землі рухається тільки $1,2 \cdot 10^{17}$ Дж/с енергії. Але це в 1600 разів більше енергії, яку споживають люди на Землі [1].

Фотоелектрична генерація - це процес прямого перетворення сонячного випромінювання в електричну енергію. Даний процес стає можливим при використанні фотоефекту - явища, що відбувається в речовинах при їх освітленні (тобто впливом електромагнітним випромінюванням).

Фотоефект ділиться на два види:

- фотоелектрична емісія - (зовнішній фотоефект) - вихід електронів з металів;

- вентильний фотоефект (внутрішній фотоефект) - переміщення зарядів через кордон розділу провідників з різними типами провідності.

Фотоелектрична генерація заснована на існуванні вентильного фотоефекту, який виникає при використанні напівпровідників.

Напівпровідники - це провідники струму, в яких концентрація носіїв заряду залежить від їх температури. При низьких температурах напівпровідники мають досить великий питомий опір і практично $є$ ізоляторами, але при збільшенні температури їх питомий опір зменшується (на відміну від металів). До них відносяться такі елементи, як кремній, германій, селен, оксид міді $\mathrm{C}_{2} \mathrm{O}$, сірчистий свинець $\mathrm{PbS}$ та ін. Наприклад, у кремнію $\mathrm{r}=10^{3} \mathrm{OM} \cdot \mathrm{M}, \mathrm{n}=10^{17}$ електрон $/ \mathrm{m}^{3}$ при $\mathrm{t}=$ $20^{\circ} \mathrm{C} ; \mathrm{r}=10^{-3} \mathrm{OM} \cdot \mathrm{M}, \mathrm{n}=10^{24}$ електрон/м при $\mathrm{t}=700^{\circ} \mathrm{C}$. Сильна залежність концентрації носіїв заряду в напівпровідниках від температури показує, що в цьому випадку електрони провідності виникають під дією теплового руху. Електрони провідності - це електрони не взаємопов'язані з атомом, вони виникають при передачі їм енергії, так званої енергією іонізації.

Чим вище температура напівпровідника, тим більше електронів матиме енергію, більшу енергії іонізації, тим більша частина електронів буде перебувати в напівпровіднику в незв'язаному з атомом стані. 
Розглянемо утворення електронів провідності в напівпровідниках на прикладі кремнію. Атом кремнію має порядковий номер $\mathrm{z}=14$. Отже, до складу атома входить 14 електронів. При цьому десять електронів міцно пов'язані з ядром і утворюють остов атома, що має заряд $+14 \mathrm{e}-10 \mathrm{e}=+4 \mathrm{e}$.

У зовнішній оболонці атома є чотири електрона, порівняно слабо пов'язані 3 ядром, звані валентними і утворюють негативний заряду 4е- . Саме ці слабо зв'язані електрони вступають в хімічні реакції, тому кремній є чотиривалентним елементом.

Електронно-діркові зв'язки кремнію досить міцні і при низьких температурах не розриваються. Тому кремній при низькій температурі не проводить електричний струм. Беруть участь у зв'язку атомів валентні електрони міцно прив'язані до електричної решітки, і тому зовнішнє електричне поле не робить помітного впливу на їх рух.

При нагріванні кремнію кінетична енергія валентних електронів підвищується i настає розрив окремих зв'язків. Деякі електрони стають вільними, подібно електронам в металі. В електричному полі вони переміщуються між вузлами решітки, утворюючи електричний струм.

Провідність напівпровідників, обумовлену наявністю у них вільних електронів, називають електронною провідністю. При підвищенні температури число розірваних зв'язків, а значить, і вільних електронів збільшується.

Крім того, при розриві зв'язку утворюється вакантне місце 3 відсутнім електроном. Таке місце називають діркою. У дірці $є$ надлишковий позитивний заряд в порівнянні з іншими, нормальними зв'язками. Положення дірки в кристалі не $\epsilon$ незмінним. Безперервно відбувається наступний процес. Один з електронів, що забезпечують зв'язок атомів, перескакує на місце де утворилася дірка i встановлюється тут електронно-дірковий перехід, а там, звідки перескочив цей електрон, утворюється нова дірка. Таким чином, дірка може переміщатися по всьому кристалу. При цьому дірки мають позитивний заряд і поводяться як позитивно заряджені частинки. Така провідність називається дірковою.

P-n-перехід являє собою тонкий шар на переході між двома областями одного і того ж кристала, що відрізняються типом домішкової провідності.

У n-області основні носії струму - електрони, а неосновні - дірки. Дифундуючи в зустрічних напрямках через перехідний шар, дірки і електрони рекомбінують один 3 одним. Тому p-n-перехід виявляється сильно збідненим носіями струму і набуває великий опір. Одночасно на кордоні між областями виникає подвійний електричний шар, утворений негативними іонами акцепторної домішки, заряд яких тепер не компенсується дірками, і позитивними іонами донорної домішки, заряд яких тепер не компенсується електронами.

Типова структура сонячного елемента 3 p-n-переходом на основі монокристалічного кремнію зображена на рис. 1. Вона включає: шар напівпровідника (товщиною 0,2-1,0 мкм) 3 n-провідністю 1, шар напівпровідника (товщиною 250-400 мкм) з р-провідністю 2, додатковий потенціальний бар'єр (товщиною 0,2 мкм) 3, металевий контакт 4, зовнішній металевий контакт 5. Характерний розмір сонячного елемента 10 см [1].

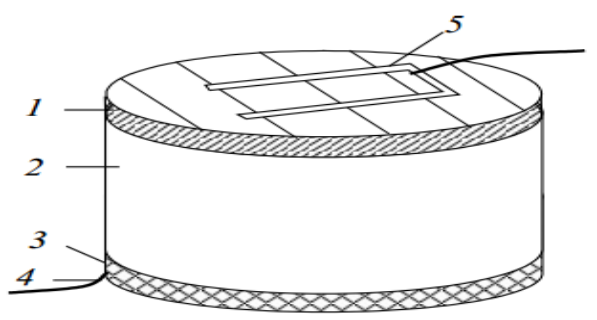

Рис 1. Конструкція сонячного елемента 
Недоліки сонячних елементів: висока вартість, низький ККД, зміна робочих параметрів (напруга і струму) сонячного елемента при зміні навантаження, вироблення постійного струму.

Сонячні елементи характеризуються коефіцієнтом перетворення сонячної енергії в електричну, який являє собою відношення максимальної потужності виробленої елементом електричної енергії до енергії потоку випромінювання, що падає на елемент. Кремнієві сонячні елементи (рис.2) мають коефіцієнт перетворення 10-15\% (тобто при освітленості 1 кВт/м² виробляють електричну потужність 1-1,5 Вт) при створюванні різниці потенціалів приблизно 1 В.
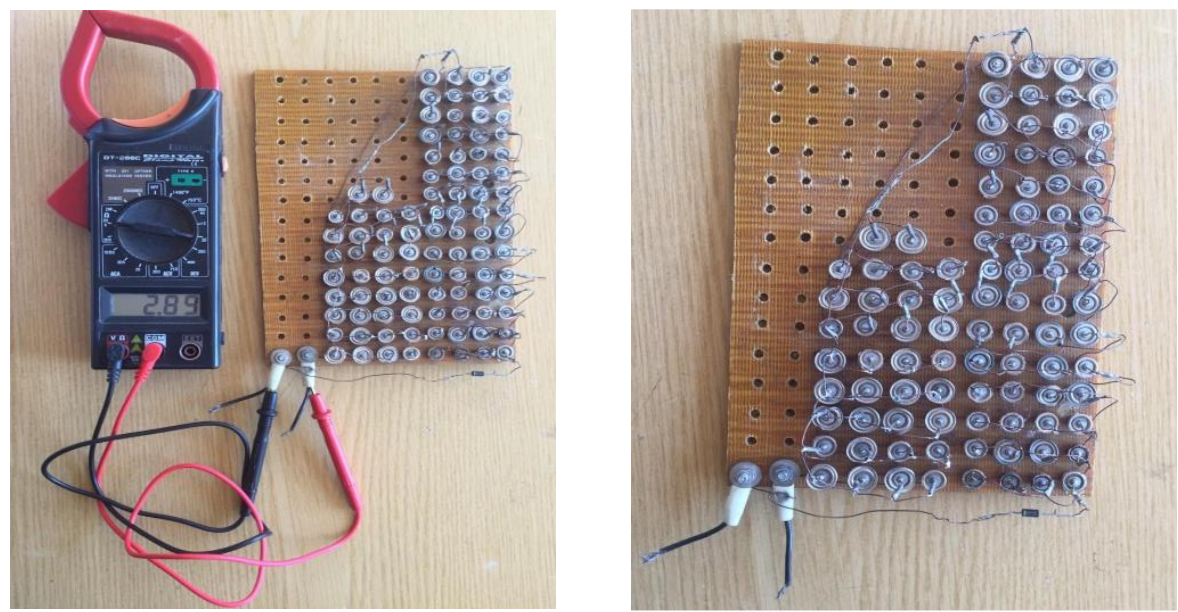

Рис 2. Перетворення сонячної енергії в електричну

Висновок. Перевага використання сонячних батарей - сонце, як невичерпне джерело енергії. Україна для сонячних батарей знаходиться в сприятливій зоні, більш вигідною ніж Німеччина або Франція.

Перетворення енергії нетрадиційного відновлювального джерела на рівні сучасних знань і технологій обходиться досить дорого. Однак у всіх випадках його використання призводить до еквівалентного зниження витрат органічного палива i меншого забруднення навколишнього середовища.

\section{Список використаних джерел:}

1. Сухоцкий, А. Б. (2009) Нетрадиционные и возобновляемые источники энергии. Энергоэффективные технологии и энергетический менеджмент, 13-62. Вилучено з: https://elib.belstu.by/bitstream/123456789/2702/1/suxockii-netradicionnye-istochniki-ehnergii.pdf

2. Твайделл, Дж . Возобновляемые источники энергии / Дж. Твайделл, А. Уэйр; пер. с англ. - М.: Энергоатомиздат, 1990. - 392 с. 
Довженко Богдана Ігорівна, здобувач вищої освіти факультету електроніки Національний технічний університет України «Київський політехнічний інститут імені Ігоря Сікорського», Украӥна

\section{ПРИЛАД ДЛЯ АНАЛІЗУ ТА КОНТРОЛЮ МІКРОКЛІМАТУ В ТЕРАРІУМІ ДЛЯ РЕПТИЛІЙ}

Вступ. На сьогоднішній день досить часто можна зустріти екзотичних домашніх тварин. I хоча список рептилій, які можуть проживати 3 людьми невеликий, вони вдало відсувають на другий план звичних нам котів на собак. При покупці екзотичного улюбленця варто пам'ятати, що на першому етапі потрібно якнайкраще створити певні умови для проживання конкретного виду. Якщо господар не готовий одразу до певних витрат та зусиль, то це може призвести до страждання тварини, навіть до летальних випадків включно.

Постановка проблеми. Для того щоб тварина почувала себе комфортно, потрібно створити умови проживання близькі до природнього середовища [1]. Для холоднокровних рептилій, таких як: черепахи, ящірки, змії найбільш вагомі є два аспекти при створенні кліматичних умов, це дотримання температурного режиму та наявність ультрафіолетового випромінювання. Слід, зазначити, що таким улюбленцям потрібно створювати дві зони: зона теплого кутку та холодного. Якщо температура в теплому кутку буде нижче потрібної, це може призвести до сповільненого метаболізму, а якщо зависока - до перегріву, який може спричинити смерть улюбленця. Ультрафіолетове випромінювання важливо, для засвоєння шкірою вітаміну D3 [2], який допомагає регулювати мінеральний обмін, забезпечувати кістки кальцієм. Через відсутність такого випромінювання у рептилій може виникнути остеомаляція.

Аналіз існуючих аналогів. Для того, щоб забезпечити хороші умови рептиліям можна використовувати окремі прилади, такі як: термометр, лампу розжарювання та лампу ультрафіолетового випромінювання. Також, можна використовувати прилади, які поєднують у собі кілька пристроїв, наприклад, фірма Lucky Reptile [3], випускає контролери температури, які мають давач, та в залежності від його значення виконують обігрів/охолодження середовища. Вимірювання ультрафіолету можна забезпечити завдяки приладам, на кшталт Yieryi. Проте, не існує приладу, який б забезпечував вимір ультрафіолетового випромінювання та температури одночасно. А використання кількох приладів забирає площу тераріуму і унеможливлює забезпечення селективності по підтримці потрібних значень системи.

Мета роботи. Виходячи з недоліків описаних аналогів, за мету поставлено створення пристрою, який вимірює температуру в теплій та холодній зоні; контролює температуру в теплій зоні. Для цього він повинен керувати вимиканням/вмиканням лампи обігріву, а у випадку коли терміново необхідно знизити температуру, пристрій буде вмикати вентилятор, який розташовано таким чином, щоб відбувався забір теплого повітря. Ще одною, не менш важливою функцією приладу $є$ аналіз справності ультрафіолетової лампи. Так як для кожного виду рептилії необхідно мати свій спектр випромінювання, то аналізувати довжини хвилі немає потреби, а лише фіксувати працездатність лампи. Для рептилій важлива і зміна денного та нічного режиму. Тому прилад буде виконувати і функцію зміни режимів.

Структура приладу. Структурна схема приладу зображено на рис.1. Прилад оснащено 2-ма давачами температури для вимірювання поточного значення в 2-х 
зонах. Давач ультрафіолетового випромінювання слідкує за працездатністю лампи ультрафіолету. Використовуючи панель керування, користувач може задати параметри, які потрібно підтримувати. Блок, що відповідає за контроль реального часу, фіксує поточну годину.

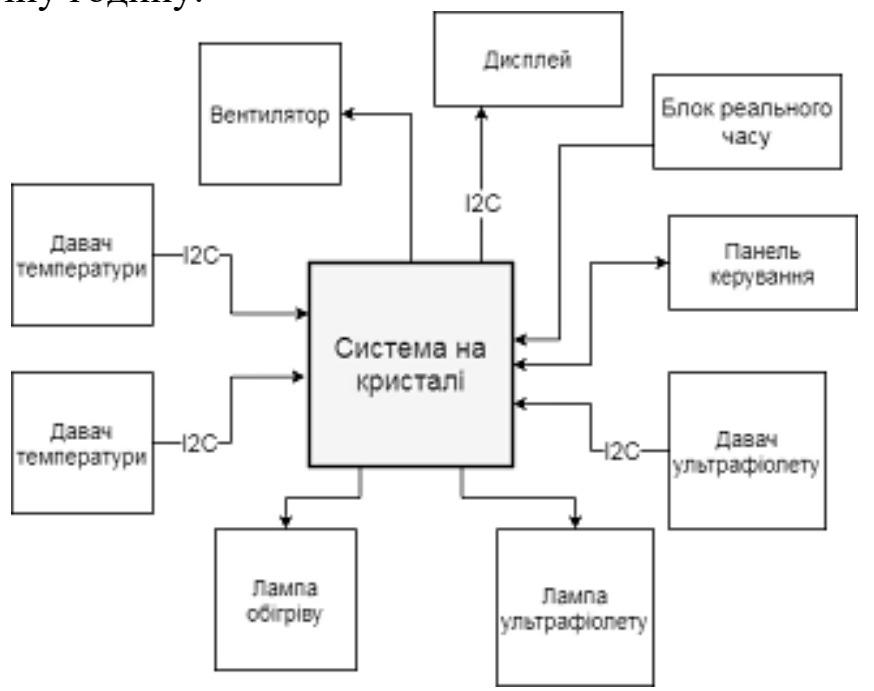

Рис.1 Структурна схема приладу

Як видно, система на кристалі відіграє ключову роль - в ній відбуваються всі розрахунки.

Симуляція роботи приладу. Симуляцію роботи було проведено в середовищі Modelsim. Логіка роботи приладу створена завдяки мови опису апаратури Verilog [5].

Алгоритм роботи головного блоку наведено на рис. 2. Зчитування, нових даних 3 давачів відбувається що хвилини.

На рис.3 зображено результат моделювання, де присутні наступні сигнали:

- Тетр - відповідає за виміряну температуру в теплому кутку;

- Light - відповідає за рівень ультрафіолетового освітлення;

- Timer - частота, для слідкування за часом;

- Temp_cont - контролювання включення/виключення лампи обігріву(1 лампа обігріву увімкнена, коли 0 - вимкнена);

- Light_cont - контролювання включення/виключення лампи ультрафіолету;

- Fan_cont - - контролювання включення/виключення вентилятора(1 вентилятор увімкнений, коли 0 - вимкнений);

- Start_t - початок вимірювання температури(оскільки при включені потрібно зачекати деяких час, щоб температура в тераріумі нагрілася);

-N_sleep - коли приладу не працює(120 - прилад вимикається);

-Sleep - коли прилад працює(80 - прилад вмикається).

За сталу температуро обрано $33^{\circ} \mathrm{C}$ з можливим відхиленням в $+2^{\circ} \mathrm{C},-4^{\circ} \mathrm{C}$.

Коли температура занизька, то сигнал Temp_cont $=1$. Якщо протягом деякого часу нічого не змінюється, то повідомляється користувача про проблему та вимикається лампа. Коли температура зависока, то Temp_cont $=0$. Якщо через деякий час ситуація не змінюється, то вмикається вентилятор Fan_cont $=1$.

Опираючись на те, що значення ультрафіолетового випромінювання знати не потрібно, то взяли за бажане значення 400Лк. Якщо менше цього значення (Light_cont $=0$ ) деякий період часу, тоді припускається, що лампа ультрафіолету вийшла з ладу. Якщо рівно 400Лк(Light_cont =1) та більше, лампа - справна. 


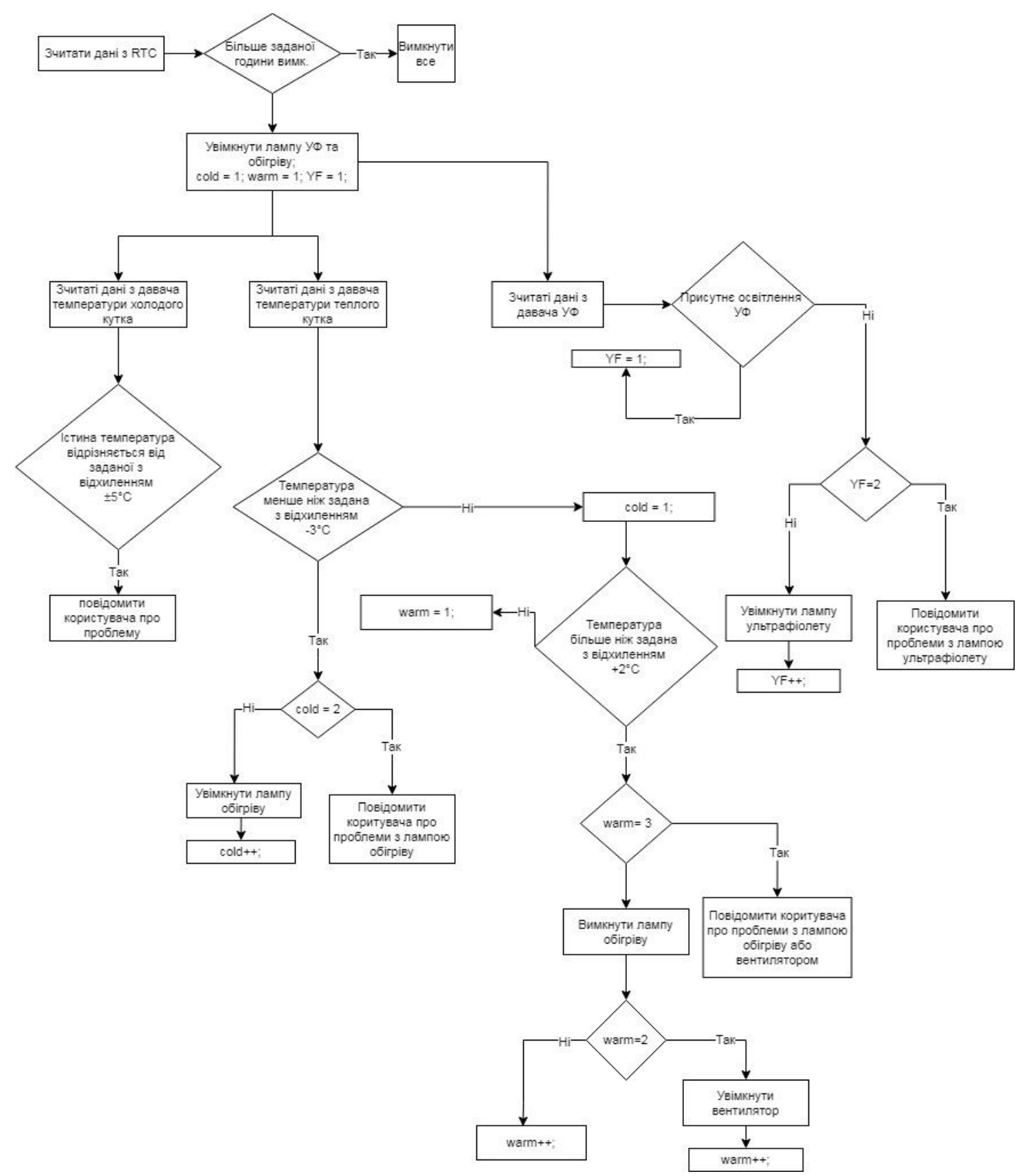

Рис. 2. Алгоритм роботи пристрою

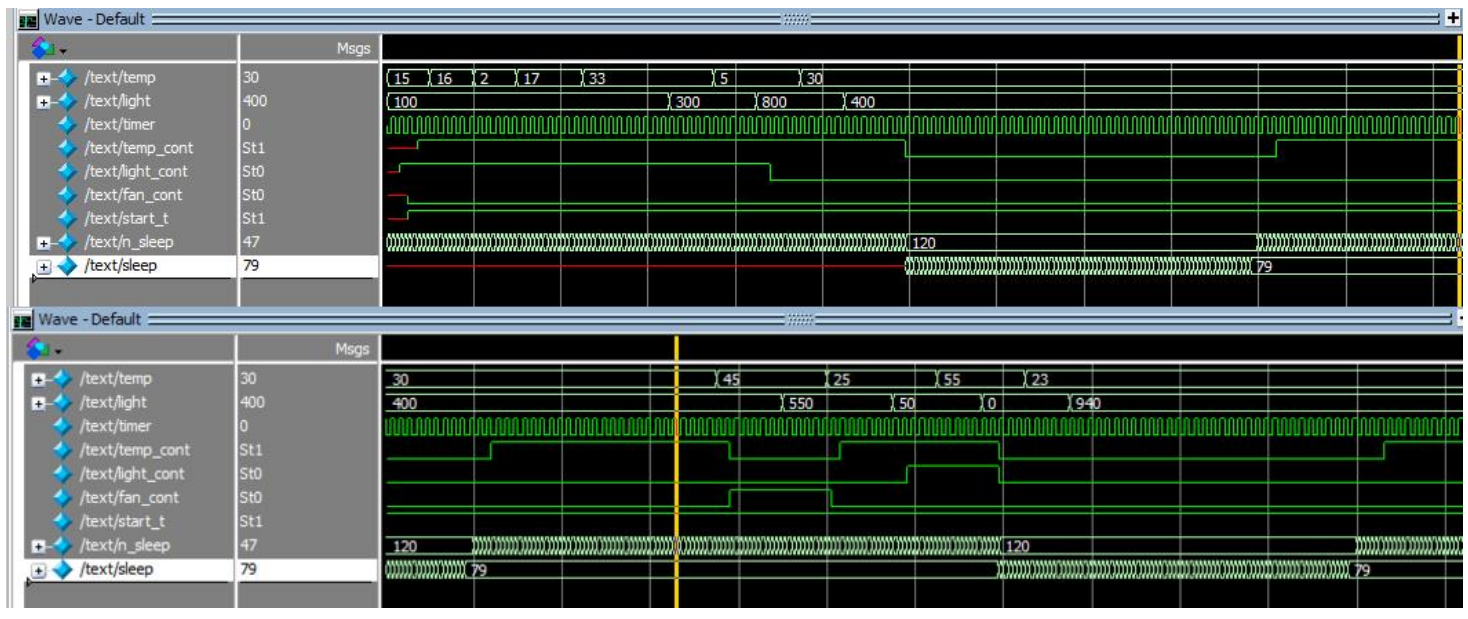

Рис.3. Симуляція роботи приладу 
Реалізація. Прилад було реалізовано на ПЛІС сімейства CycloneII [6], виконано синтез цифрової схеми із зазначеного опису в САПР QuartusPrime. Для перевірки працездатності макета приладу тестувався програмний код, алгоритм якого зображено на рис.2, та за допомогою вбудованого логічного аналізатора Signal-Tap Logic Analyser [7].

Було перевірено 4-ри режими роботи приладу (рис. 4 (а-г)):

- Show_light $=4$, show_temp =4: низька температура, відсутнє ультрафіолетове освітлення;

- Show_light $=1$, show_temp =1: температура в нормі, наявне ультрафіолетове освітлення;

- Show_light $=3$, show_temp $=1$ : температура вище заданої, наявне ультрафіолетове освітлення;

- Show_light $=0$, show_temp $=0$ : прилади всі вимкнуті.

Відповідно сигнал night свідчить, про нічний час (1) та денний (0).

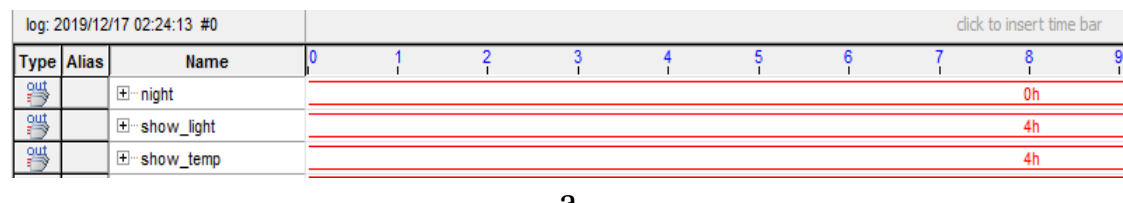

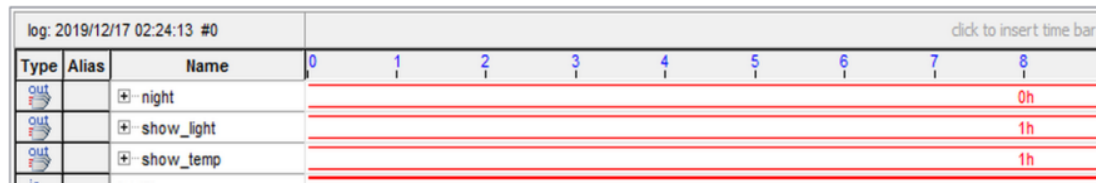

6

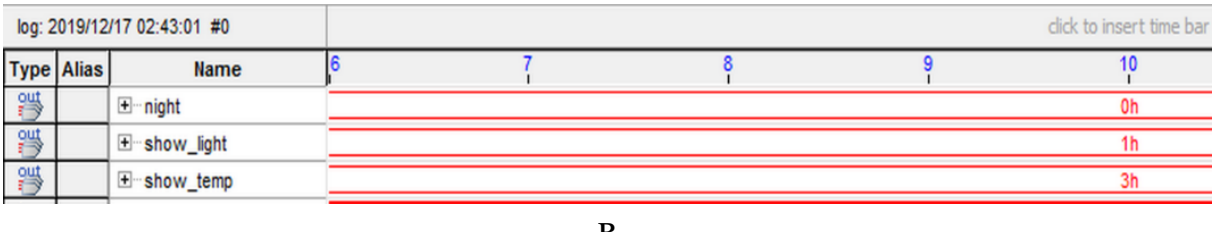

\begin{tabular}{|c|c|c|c|c|c|c|c|c|c|c|c|c|}
\hline \multicolumn{3}{|c|}{ log: 2019/12/17 02:24:13 \#0 } & \multicolumn{10}{|c|}{ click to insert time bar } \\
\hline Type & Alias & Name & 1 & 2 & $\begin{array}{l}3 \\
1\end{array}$ & 4 & $\begin{array}{l}5 \\
1\end{array}$ & $\begin{array}{l}6 \\
1\end{array}$ & $\begin{array}{l}7 \\
1\end{array}$ & 8 & 9 & $\begin{array}{c}10 \\
1\end{array}$ \\
\hline 액 & & \pm night & & & & & & & & $1 \mathrm{~h}$ & & \\
\hline 일 & & $\Phi$ show_light & & & & & & & & on & & \\
\hline out & & $\Phi$ show_temp & & & & & & & & $\mathrm{Oh}$ & & \\
\hline
\end{tabular}

Рис. 4. Результати перевірки макетного зразка приладу

(а - температура нижче необхіднӧ, несправна ламка ультрафіолетового випромінювання, бвсе працюе нормально, в-температура зависока, освітлення в нормі, г-нічний режим)

Перспективи подальшого розвитку. Для зручності введення базових параметрів користувачем, розглядається створення керуючого пристрою на базі ПЛІС з можливістю підключення до веб-серверу.

\section{Список використаних джерел:}

1. Домашние рептилии - виды и условия содержания (2013). Изъято из: https://www.molnet.ru/mos/ru/pets/o_46153

2. Метаболическая болезнь костей у рептилий (2017). Изъято из: https://www.zoovet.ru/stati/publikatsii-spetsialistov/reptilii/metabolicheskaya-bolezn-kostey-u-reptiliy

3. Instructions Operating,(2006) Thermo Control Pro $2 . \quad$ Retrieved from: https://usermanual.wiki/Pdf/ThermoControlPro2.124322525/view

4. Corporation Xilinx, Verilog Reference Guide. Retrieved from: http://in.ncu.edu.tw/ncume_ee/digilogi/vhdl/Verilog_Reference_Guide.pdf

5. Corporation Altera, (2007) "Cyclone II Device Handbook." Retrieved from: www.altera.com 
6. Corporation Intel,(2017) “14 Design Debugging with the Signal Tap Logic Analyzer," Retrieved from. https://faculty-web.msoe.edu/johnsontimoj/Common/FILES/qts-qps-5v3_signaltap_17.1.pdf

Острянко Олександр Володимирович, здобувач вищої освіти факультету електроніки

Національний технічний університет Украӥни «Київський політехнічний інститут імені Ігоря Сікорського», Україна

\section{ПРИСТРІЙ ДЛЯ ПЕРЕВІРКИ СПРАВНОСТІ РОБОТИ ЕЛЕКТРОННИХ СИСТЕМ АВТОМОБІЛЯ}

Вступ. На сьогоднішній день діагностувати несправність електронної системи можна лише на спеціалізованому автомобільному сервісі, де наявне необхідне устаткування. Проте не секрет, що обслуговування автомобіля на сервісі задоволення не з дешевих. Окрім того, для проходження обслуговування, необхідно дочекатися своєї черги, яка може звільнитися лише в наступному місяці. Така ситуація змушує відмовитися від несправного автомобіля на цей період часу.

Електронні системи автомобіля. Комплектація автомобіля електронними системами варіюється в залежності від типів машин (автомашини, трактори, комбайни, навантажувачі, тощо). Проте з усіх типів систем до числа обов'язкових можна віднести наступні електронні системи [1]:

-Системи управління електрообладнанням;

-Системи управління двигуном;

-Системи управління трансмісією;

-Системи управління коробкою передач [2]-[4];

-Електронні системи управління підвіскою;

-Системи забезпечення комфорту і мікроклімату [5], [6];

-Системи активної безпеки.

Кожна з цих систем може мати різні конфігурації в залежності від типу автотранспортного засобу.

Структура та опис роботи приладу. Даний прилад слідкує за датчиками обертів двигуна та вихідного валу, положенням селектора коробки передач та температурою в автомобілі. Структурну схему підключення приладу зображено на рис. 1 нижче.

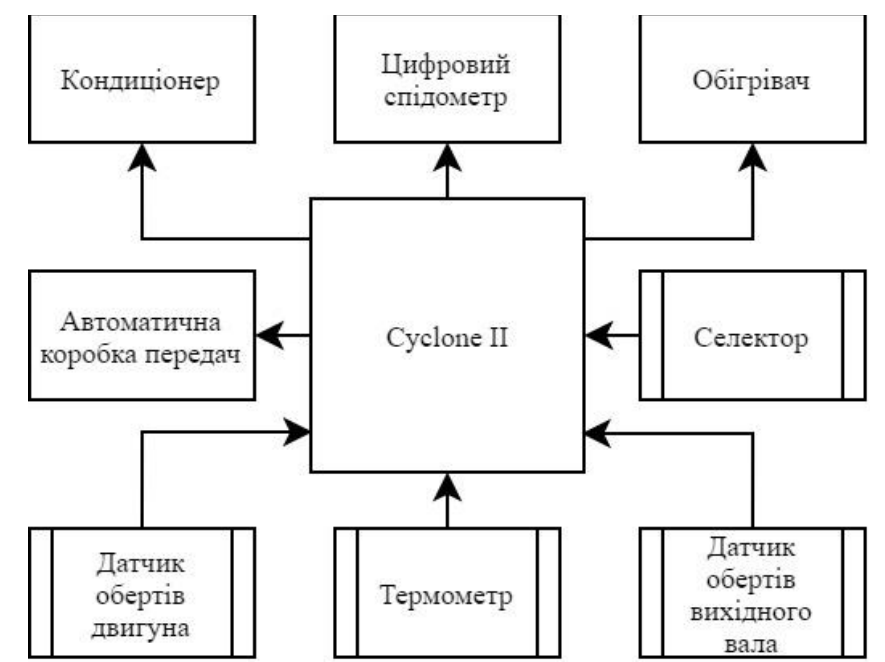

Рис 1. Структурна схема підключення приладу 
Прилад виконує наступні функції:

Клімат-контролю: відповідно до поточної температури середовища в автомобілі та значення яке виставлено на термостаті подається сигнал на обігрівач чи кондиціонер, в залежності від різниці між значеннями. У свою чергу сигнал містить у собі інформацію про потужність 3 якою необхідно підігрівати/охолоджувати повітря [7].

Спідометра: відповідно до частоти імпульсів які надходять 3 вихідного валу, відбувається перерахунок поточної швидкості автомобіля, з подальшим виводом значення на екран.

Тахометра: аналогічно з принципом роботи спідометра - частота імпульсів 3 датчика на колінчастому валі перераховується в кількість обертів за хвилину.

Блоку керування автоматичною коробкою переключення передач: відповідно до порогових значень швидкості обертів двигуна та швидкості автомобіля, даний прилад слідкує за поточними значеннями, та відсилає сигнали про перемикання передач.

Симуляція роботи блоку спідометра. Симуляцію роботи було проведено в середовищі Modelsim -багатомовному середовищі моделювання HDL від Mentor Graphics для моделювання мов опису апаратних засобів, таких як VHDL, Verilog i SystemC, і включає вбудований відладчик мови Ci.

Виходячи $з$ опису роботи даного блоку, наведеного вище, можна зробити наступний висновок - чим менша відстань між двома сусідніми вхідними імпульсами, тим більша швидкість автомобіля.

Симуляцію та розрахунок швидкості проведено відповідно до використаного кристалу Cyclone II ep2c35f672c6, з тактовою частотою 50 МЦг. Іншими словами, симуляцію проведено відносно реального часу, та реальної роботи приладу.

На рис. 2 нижче зображено весь часовий відрізок симуляції.
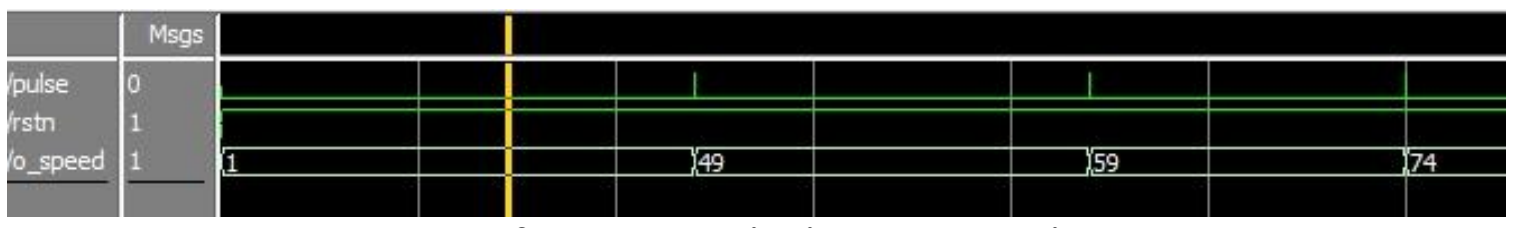

Рис 2. Часовий відрізок симуляції

3 рисунку видно:

1. Після «ресету» початкове значення швидкості - 1 км/год;

2. Спостерігається найбільша відстань між імпульсами, що відповідає значенню швидкості 49 км/год;

3. Наступний відрізок між імпульсами дещо коротший, відповідно і швидкість більша - 50 км/год;

4. Останній відрізок, найбільш коротший з наведених - 74 км/год.

Симуляція роботи блоку керування автоматичною коробкою переключення передач.

На рис. 3 нижче зображено проведене моделювання в загальному вигляді. На рисунку присутні наступні чотири сигнали:

-i_selector - відповідає за положення ручки селектора коробки передач автомобіля;

-i_speed - відповідає поточній швидкості автомобіля;

-i_engine_speed - відповідає поточній швидкості оборотів двигуна;

-o_gear - відповідає поточній передачі; 

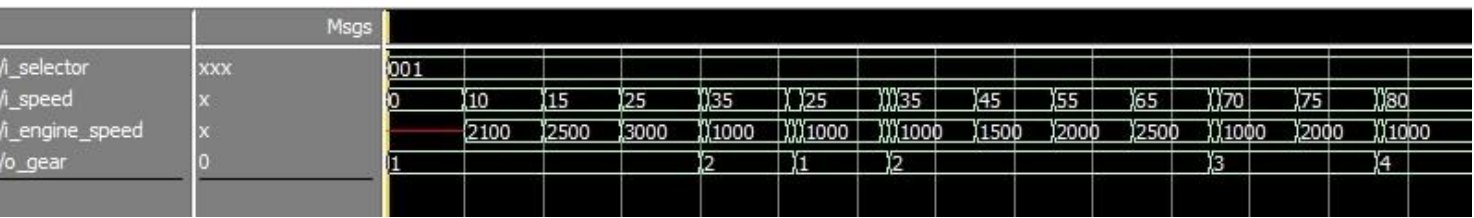

Рис 3. Загальний часовий відрізок моделювання

На даному рисунку видно наступне:

1. Положення ручки селектора в продовж всього моделювання відповідає значенню 1 - це значення відповідає режиму «Drive» в перекладі «Рух». В даному режимі коробка передач працює автоматично, перемикаючи передачі відповідно до швидкості руху та швидкості обертів двигуна.

2. Спочатку швидкість руху та швидкість обертів двигуна поступово збільшується до значень 36 км/год та 3100 об/хв, після чого відбувається переключення передачі з першої на другу. Цей момент зображено окремо на рис. 4 нижче.

3. Далі швидкість руху та швидкість обертів зменшується до 29 км/год та 500 об/хв, після чого передача переключається вниз, тобто з другої на першу. Цей момент зображено окремо на рис. 5 нижче.
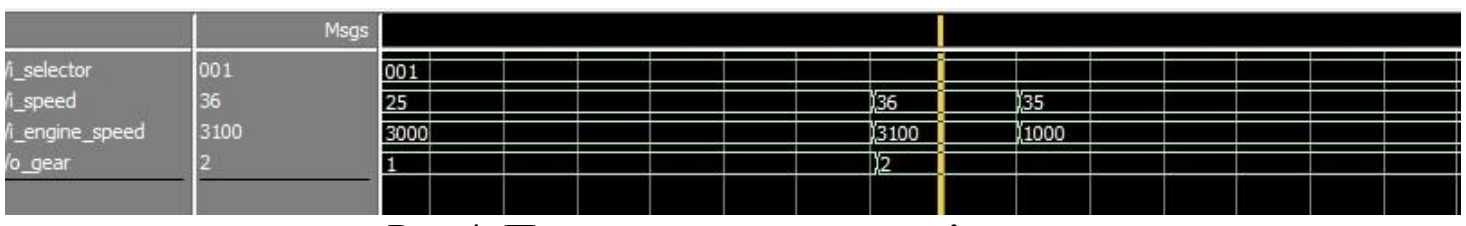

Рис 4. Переключення передачі вверх
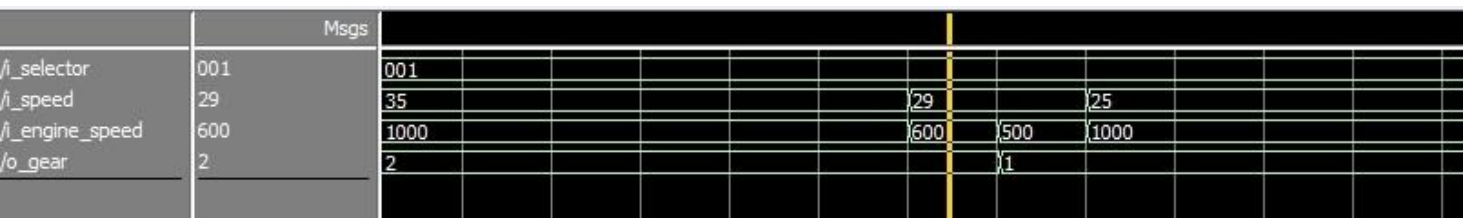

Рис 5. Переключення передачі вниз

Таким чином було модельовано роботу блоку керування АКПП. Можна зробити висновок що блок працює коректно, адже отримані результати відповідають очікуванням. Порогові значення швидкості обертів двигуна для тестування було взято однаковими для всіх передач - 500 об/хв у якості нижнього порогового значення та 3000 об/хв у якості верхнього порогового значення.

Напрямки подальшого застосування приладу. У подальшому, прилад може знайти застосування як на невеликих сервісних центрах чи СТО, так і у домашніх умовах для користувачів, які полюбляють самостійно доглядати за своїм автомобілем. Адже саме це і було метою для розробки: прилад який не є громіздкий, дешевий у порівнянні з спеціальним тестувальним обладнанням та досить простий у використанні.

\section{Список використаних джерел:}

1. Світ електронних систем Ua.nauchebe.net (2015) "Електронні системи керування автомобілями" Вилучено iз http://ua.nauchebe.net/2015/04/elektronni-sistemi-keruvannya-avtomobilyaminapivprovidnikova-silova-elektronika/.

2. Sun Devil Auto "What Is a Transmission Control Module?" Retrieved from https://www.sundevilauto.com/what-is-a-transmission-control-module/.

3. Tsukasa Azuma (2018) "Transmission Control Module Symptoms: Learn The Bad Ones" Retrieved from https://carfromjapan.com/article/car-maintenance/transmission-control-module-symptoms/. 
4. Andrew Markel (2017) "Solving Automatic Transmission Electronic Control Problems" Retrieved from https://www.brakeandfrontend.com/solving-automatic-transmission-electronic-control-problems/.

5. Rocco Lovetere (2016) "How to Troubleshoot a Broken Car Air Conditioner" Retrieved from https://www.yourmechanic.com/article/how-to-check-a-broken-air-conditioner.

6. EDN (2012) "Fundamentals of the automotive cabin climate control system" Retrieved from https://www.edn.com/fundamentals-of-the-automotive-cabin-climate-control-system/.

7. Michael Fernie (2016) "How Do Climate Control And Air Conditioning Systems Actually Work?" Retrieved from https://www.carthrottle.com/post/how-do-climate-control-and-air-conditioning-systemsactually-work/.

Драга А. Ю., здобувач вищої освіти другого (магістерського) рівня Херсонський державний аграрно - економічний університет, Україна

Науковий керівник: Новікова Н. В., к.с.г.н., доцент

Херсонський державний аграрно - економічний університет, Україна

\section{ПРОБЛЕМИ ТА ПЕРСПЕКТИВИ ВИКОРИСТАННЯ ПРЯНО - АРОМАТИЧНОЇ СИРОВИНИ В ТЕХНОЛОГІЯХ ХЛІБОБУЛОЧНИХ ВИРОБІВ}

Останні 20 років спостерігається стрімке зростання популярності пряно ароматичної сировини в країнах $\mathrm{CC}$, США та інших, що зумовлено іiі різновекторними фізіологічними та технологічними властивостями. Завдяки багатовіковим традиціям її використання при виготовлені продуктів харчування, в побуті і величезному досвіду народної медицини, споживачами пряно - ароматична сировина розцінюється як природна корисна і безпечна.

Фітосировина, що потенційно здатна інтенсифікувати мікробіологічні процеси при дозріванні напівфабрикатів, а також 3 вмістом вітамінів, поліфенольних речовин, органічних кислот $є$ перспективною з огляду можливості зниження вмісту акриламіду в ХБВ. Крім того, сполуки з антиоксидантними, антисептичними властивостями фітосировини, iї оригінальний смак і аромат дозволяє розглядати питання можливості попередження мікробіологічного, окиснювального псування виробів тривалого зберігання, зменшення вмісту ХД у сухариках, грінках, снеках, що входять у десятку лідерів небезпечних продуктів харчування [1].

Проте, незважаючи на цінність фізіологічних властивостей, перспектив використання у виробництві, впровадження технологій продуктів харчування 3 пряно - ароматичної сировини в Україні здійснюється достатньо повільно, що зумовлено низкою проблем, які потребують пошуку шляхів вирішенн

В Україні вченими Махинько В.В. зі співавторами [2] досліджено можливість включення до рецептури ХБВ порошків дикорослих трав кропиви, деревію, материнки, грициків і вказано на підвищення ХЦ та БА продукції. При цьому зазначено збільшення водопоглинальної здатності борошна та зміни кольору, консистенції м'якушки під впливом фітодобавок. Використання порошків, подрібнених фітодобавок, має ряд недоліків, пов'язаних з погіршанням товарного вигляду продукції, кольору, консистенції м'якушки, швидкими темпами мікробіологічного псування, втратою БА, якості, зокрема аромату подрібненими ЛПАРС тощо. Тому набувають популярності роботи, в яких передбачено попередню підготовку фітодобавок, наприклад екстрагування. Особливу увагу вчених [3], 
привертає зелений чай, який є складним за своєю природою продуктом, містить більше 300 речовин та сполук.

Розроблено спосіб приготування хліба, де в якості функціонального інгредієнта використовується екстракт зеленого чаю, що забезпечує підвищення вмісту широкого спектру, оптимально збалансованих з вітамінами групи В, макро-, мікроелементів. Вживання таких ХБВ, за свідченнями авторів винаходу, $\epsilon$ профілактичним заходом проти багатьох сучасних неінфекційних захворювань. Для приготування хліба з високою ХЦ, заданими фізіологічними властивостями, який рекомендується для оптимізації кисневого обміну в організмі людини, поліпшення засвоюваності білків і мікроелементів запропоновано композицію з вмістом соку обліпихи, екстракту чистотілу і люцерни. Спосіб цікавий тим, що екстракти готуються на МС. Цим же авторським колективом розроблено технологію хліба «Тибет», що дозволяє покращити засвоювання білків та вуглеводів. У Дагестанському державному технічному університеті науковці також пропонують використовувати МС як основу для отримання екстрактів з ягід калини й барбарису, що використовуються в технології пшеничного хліба [4]. Водні екстракти з квіток липи, листя кропиви, естрагону також знайшли своє застосування у технології ХБВ 3 підвищеними фізіологічними властивостями та оригінальним смаком.

Щетиніним М.П. у співавторстві розроблено спосіб використання соку обліпихи для виробництва ХБВ функціонального призначення [5]. Знижувати ліпідне навантаження на організм людей, схильних до ожиріння та атеросклерозу, за допомогою ХБВ з використанням екстракту виноградних вичавок пропонують у П'ятигорському державному технологічному університеті [6], сам екстракт отримують шляхом ультразвукової або СВЧ екстракцій.

\section{Список використаних джерел:}

1. Щеголева, И. Д. \& Мойсеяк, М. Б. (2014) Применение зеленого чая в технологии производства пшеничного хлеба. Хлебопечение, (2), 18-20.

2. Махинько, В. М., Даньшіна, Л. О. \& Махинько Л. В. (2011) Використання дикорослих харчових трав у хлібопеченні. Хранение и переработка зерна, (1), 55-57.

3. Пучкова, Л. И., Белявская, И. Г., \& Жамукова Ж. М. (2014) Экстракт зеленого чая - источник биофлавоноидов в хлебобулочных изделиях функционального назначения. Хлебопечение, (2), 26 $-28$

4. Музалевская, Р. С. \& Батурина Н. А. (2014) Булочные изделия с добавками дикорастущих лекарственных растений. Известия ВУЗов. Пищевая технология, (1), 66-67.

5. Щетинин, М. П. (2018) Влияние облепихового сока на качество хлеба. Хранение и переработка сельхозсырья, (12), 78-80

6. Кондратьев, Д. В., \& Щеглов, Н. Г. (2019) Способы получения екстракта виноградных выжимок и возможности его использования в пищевой промышленности. Известия ВУЗов. Пищевая технология. (1), 62-64 
Чумак Олена Віталіївна, здобувач освітнього рівня «магістр» факультету інтегрованих технологій

Херсонський національний технічний університет, Україна

Науковий керівник: Стоянова Ольга Вікторівна, канд.техн.наук, доцент, доцент кафедри харчових технологій

Херсонський національний технічний університет, Украйна

\section{ПРОЕКТУВАННЯ ТЕХНОЛОГІЇ ФРУКТОВИХ ДЖЕМІВ ДЛЯ ПРОФІЛАКТИЧНОГО ХАРЧУВАННЯ}

Виробництво концентрованих фруктових консервів (повидло, джеми, варення) спрямовано на вдосконалення існуючих технологій або на розширення асортименту продуктів харчування, поліпшення їх якості та придбання функціональної спрямованості. Актуальним у всьому світі на сьогоднішній день $\epsilon$ розроблення спеціальних продуктів харчування для оздоровлення населення. Останнім часом, 3 урахуванням сучасних вимог науки про харчування, розширюється виробництво функціональних низькокалорійних продуктів в різних галузях харчової промисловості з використанням цукрозамінників, призначених для людей, хворих на цукровий діабет, ожиріння, серцево-судинні порушення $[1,2]$.

Теоретичні та практичні основи створення продуктів функціонального призначення з регульованим складом викладені в працях А.К. Д'яконової, Н.Н. Ліпатової, Я.О.Бачинської, Роїк, М.В, Р.Ю. Павлюк, а також інших вітчизняних і зарубіжних вчених [3-6]. В роботах обгрунтовано доцільність використання природного підсолоджувала із листя стевії при виробництві фруктових консервованих продуктів. Науковцями виявлена також антивірусна, антибактеріальна та антигрибкова активність стевіозиду; визначено сприятливу терапевтичну дію екстракту надземної частини стевії при лікуванні таких захворювань, як невралгія, анемія, люмбаго, ревматизм, екзема, дерматит [2]. Проведений аналіз даних літератури свідчить про те, що інноваційні підходи при розробки продуктів профілактичної дії (імуномодулюючої та радіозахисної) полягають у впровадженні у виробництво технологій концентрованих фруктових джемів з використанням цукрозамінників. Але, продуктивність ліній відповідного асортименту продукції невелика і виробництво має низький економічний ефект. Тому розробка технологічних схем i рецептури фруктових джемів для профілактичного харчування потребує удосконалення способів переробки сировини.

В роботі пропонується виготовляти сливовий джем 3 використанням стевіозиду для забезпечення профілактичної дії щодо розвитку цукрового діабету. Смак стевіозиду дуже схожий до смакових властивостей цукру, але коефіцієнт солодкості стевіозиду, по відношенню до цукру, складає 1: (200-300). На відміну від цукру, стевіозид не вступає в реакції меланоїди-ноутворення і не викликає потемніння продукту в процесі виробництва та зберігання. Він не зброджується мікроорганізмами, підкреслює ароматичні властивості сировини, створює насиченість смаку у продукті [4].

При визначенні масової частки цукрозамінника, керувалися коефіцієнтом солодкості, який дорівнює 1:200 (по відношенню до цукрози). Склад рецептури дозволяє знизити калорійність джему, при цьому органолептичні і фізико-хімічні властивості повністю відповідають вимогам якості. В дослідженнях використовувалися сливи сортів: персикова і Монфор. Якість сировини оцінювали за ДСТУ 8320-2015 «Слива свіжа» [7]. 
Технологічна схема включає такі операції: транспортування, зберігання, миття, видалення кісточок, бланшування, подрібнення, змішування (за рецептурою), уварювання (до 73 \% с.р.), фасування, закупорювання, стерилізація, охолодження, оформлення готової продукції.

При бланшуванні слив використовується ковшовий бланшувач безперервної дії. Плоди обробляють гострою парою (тиск пари 147 кПа). Стевіозид вносять на етапі змішування 3 сировиною після бланшування Доза його внесення обумовлюється рецептурами на виробництво фруктового джему, вона не повинна перевищувати 1000 г на 1 т джему.

У виробництві джему використовується нова технологія - boule. Цей метод передбачає розміщення фруктів в спеціальних закритих варильних ємностях при зниженому тиску $10-15$ хв, що дозволяє проводити процес кипіння при низьких температурах $\left(45^{\circ} \mathrm{C}\right)$ і отримати готовий джем високої якості. Вміст сухих речовин у джемі контролюється електронним рефрактометром і має бути не менше $73 \%$. За результатами дегустаційної комісії підприємства було отримано позитивні дані щодо органолептичних показників якості, що не суперечать вимогам відповідної нормативної документації ДСТУ 4900:2007 [8,9].

Висновки. Технологічна схема виробництва фруктових джемів 3 використанням стевіозиду дозволяє значно знизити калорійність продуктів і надати їм дієтичної спрямованості, при цьому органолептичні і фізико-хімічні властивості повністю відповідають вимогам, які висуваються до продуктів профілактичного харчування. Запропоновано сучасне технологічне обладнання для плодоовочевих підприємств малої продуктивності з метою зниження енерговитрат і підвищення прибутковості.

\section{Список використаних джерел:}

1. Мардар, М.Р. (2012). Харчовий статус населення України .Зб. наук. пр. Одеської нац. академії харчових технологій, (4/2), 167-171.

2. Адамчук, Т.В. (2012). Стевія та підсолоджувачі на ії основі. Проблеми харчування, (1/2), 57-60. Вилучено 3: http://medved.kiev.ua/web_journals/ arhiv/nutrition/2012/1-2_12/str57.pdf

3. Бачинська, Я.О., Степанова, О.А. (2013). Вдосконалення технології виробництва джемів функціонального призначення на основі екстракту стевії. Обладнання та технології харчових виробництв. Збір наукових праць, (30), 2013. Вилучено 3: http://journals.uran.ua/index.php/20794827/article/view/22080

4. Д'яконова, А.К., Свинаренко, О.М (2010). Перспективи отримання і використання цукрозамінника із листя стевії при виробництві консервів. Харчова наука і технологія, (2(11)), 6367.

5. Basu, Santanu, Shivhare, Singh, T.V. (2013). Effect of substitution of stevioside and sucralose on rheological, spectral, color and microstructural characteristics of mango jam. Food Engineering, (114 (4)), 465-476. DOI: 10.1016 / j.jfoodeng.2012.08.035.

6. Роїк, М.В., Кузнєцова, І.В. (2012). Вивчення якості стевії-сировини (stevia rebaudiana bertoni) для іiї подальшого переробляння на біоконцентрати функціонального призначення. Вестнік НПУ ХПІ, (26), 117-121.

7. Слива. Зберігання в регульованому газовому середовищі: ДСТУ 8320:2015. (2015). Київ: Держспоживстандарт України.

8. Джеми. Загальні технічні умови: ДСТУ 4900:2007. (2009). Київ: Держ-споживстандарт України.

9. Консерви. Джем, варення, повидло для діабетиків. Загальні технічні умови: ДСТУ 2905-94 (ГОСТ 30287-95) (1996). Київ: Держ-споживстандарт України. 
DOI 10.36074/17.04.2020.v2.02

Чумак Валерия Сергеевна, студент факультета биомедицинской инженерии Харьковский национальный университет радиоэлектроники, Украина

Научный руководитель: Свид Ирина Викторовна, к.т.н., доц., зав. кафедры микропроцессорных технологий и систем

Харьковский национальный университет радиоэлектроники, Украина

\section{РЕАЛИЗАЦИЯ СТРУКТУРЫ НЕЙРОННЫХ СЕТЕЙ HA FPGA}

Существуют классы проблем, таких как прогнозирование, классификация, управление, принятие решений, распознавание образов, оптимизация или анализ данных в самых различных областях. Большинство задач, возникающих в информационных системах, малоформализованные и трудно поддаются предсказанию, основанному на традиционных математических методах.

Вычислительные системы, базирующиеся на искусственных нейронных сетях, имеют ряд свойств, которые отсутствуют в машинах с архитектурой фон Неймана: обучаемость; ассоциативное, распределенное хранение данных; адаптация к изменению окружающей среды; потенциально высокая производительность; отказоустойчивость аппаратной реализации.

Искусственные нейронные сети являются системой объединённых и взаимодействующих между собой некоторых процессоров - искусственных нейронов. Одно из достоинств нейронных сетей - одновременная обработка большого количества сигналов. Большая часть реализуемых в реальном времени сетей, - это программная эмуляция, работающая на персональных компьютерах и специализированных серверах. Помимо достоинств, таких как простота, достигаемая программной эмуляцией, и повсеместная доступность персональных компьютеров, эти системы имеют и недостатки - избыточность и большую потребляемую мощность. Скорость работы нейронной сети, построенной этим образом, будет напрямую зависеть от ее размерности, так как частота работы единого центрального процессора будет делиться на все использующиеся в данной сети нейроны. Их быстродействие обратно пропорционально количеству элементов нейронной структуры.

Применяя парадигму нейронных сетей, можно создавать параллельные и распределенные структуры с высокой скоростью вычислений и большей эффективностью для реализации задач контроля и обеспечения надежности информационных систем. С ростом степени интеграции микросхем качественно меняется предел сложности систем, которые могут быть реализованы на их основе [1]. Для реализации распараллеливаемых моделей нейронных сетей возможно использовать программируемые логические интегральные схемы (ПЛИС). Большую часть элементов типичных сетей можно построить из реализуемых в ПЛИС арифметических функций. Это, в частности, позволяет построить внутреннюю реализацию достаточно гладких аппроксимаций сигмоидальных нелинейных функций. Кроме того, существует возможность использования современных интерфейсных решений в ПЛИС, связанных с управлением и программированием формы и скорости входных и выходных сигналов.

Одним из мировых лидеров по разработке и продаже программируемой пользователем вентильной матрицы (FPGA) является Xilinx [2,3]. FPGA 7 серии данной фирмы охватывают широкий спектр системных требований: от недорогих 
микросхем до устройств массового производства и сверхвысокой интеграции для высокопроизводительных систем цифровой обработки сигналов с высокой пропускной способностью [4].

Большое количество вентилей ПЛИС позволяет реализовать достаточное количество параллельно работающих нейронов, обмен данными между которыми может осуществляться внутри ПЛИС. Каналы связи между логическими элементами и внутренней памятью ПЛИС обладают высокими скоростными характеристиками. Высокая тактовая частота работы ПЛИС, параллельность функционирования логики с быстродействующими внутренними и внешними каналами передачи данных способствует высокой скорости вычислений для множества параллельно функционирующих нейронов.

Математически искусственный нейрон обычно представляют как некоторую нелинейную функцию от единственного аргумента - линейной комбинации всех входных сигналов [5]. Эту функцию называют функцией активации, функцией срабатывания или передаточной функцией нейрона. Полученный результат отправляется на единственный выход нейрона (рис. 1).

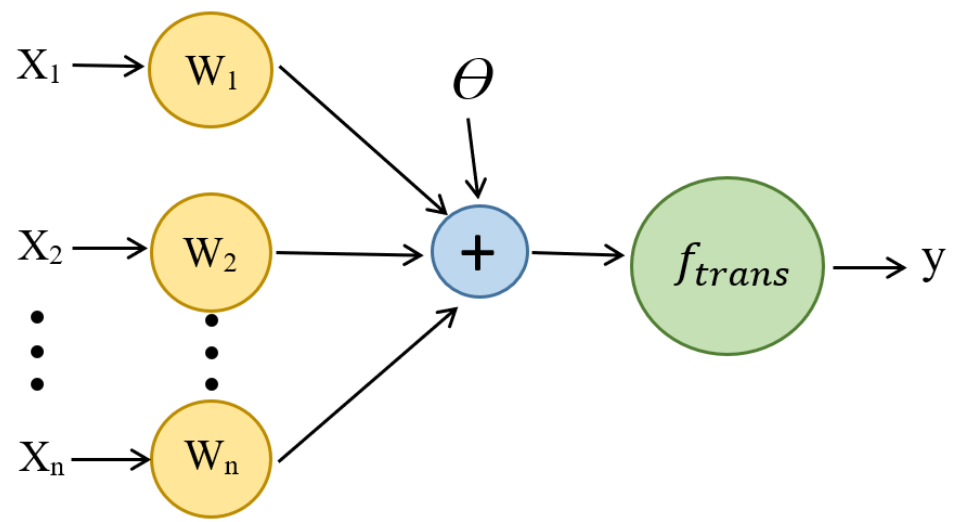

Рис 1. Математическая модель искусственного нейрона

Функция (1), которую реализует эта модель, имеет вид:

$$
\mathrm{y}=\mathrm{f}_{\text {trans }}\left(\sum \mathrm{X}_{\mathrm{i}}+\mathrm{W}_{\mathrm{i}}+\theta\right)
$$

Перед тем как строить топологию нейронной сети, сначала необходимо спроектировать структуру единичного нейрона. Ниже предлагается схема (рис. 2) замещения искусственного нейрона, разбитая на 5 функциональных блоков: входы, умножители, сумматор, нелинейный преобразователь, выход, далее используемая в ПЛИС с сохранением этих функциональных блоков.

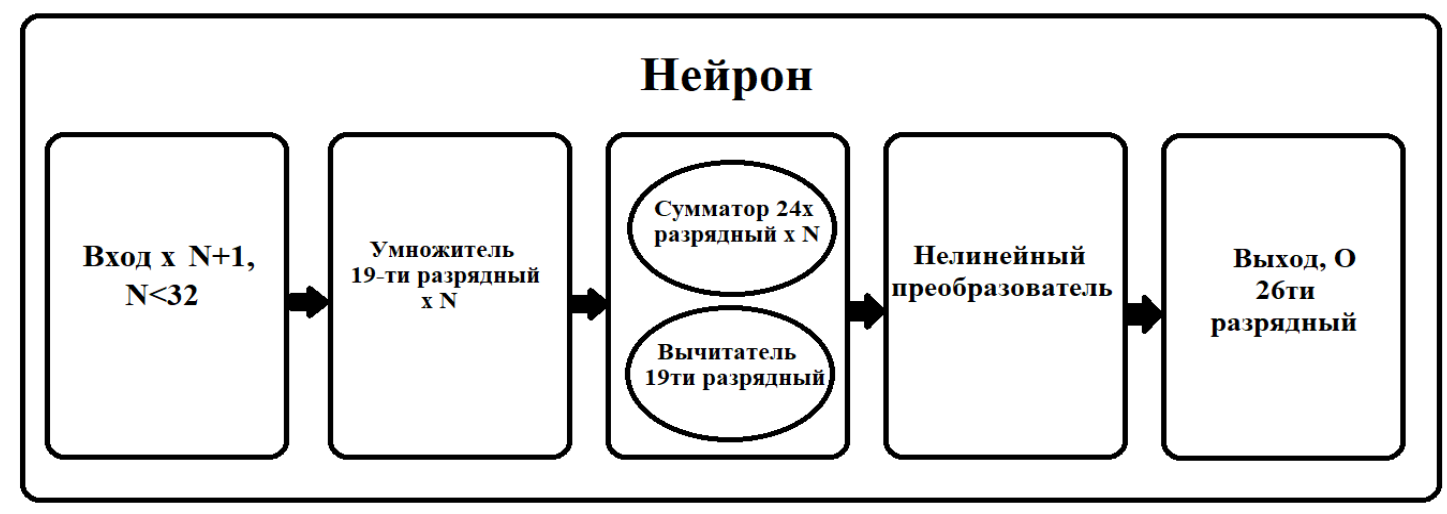

Рис 2. Схема замещения искусственного нейрона 
Входные данные - знаковые десятиразрядные числа в диапазоне [-1;1]. Старший разряд содержит знак. Веса сети и значение порога представлены девятнадцати разрядными числами.

Старший разряд знаковый, затем 9 разрядов целой части и 9 разрядов дробной части. Результат произведения весов и входных данных находится в двадцати четырёх разрядном регистре. Выходное значение находится в двадцати шести разрядном регистре.

В то время как веса и пороги искусственной нейронной сети выполнены методом простых блоков умножения и суммирования, активационная функция нуждается в применении блока памяти. То есть, в область памяти заносится таблица истинности некоторой функции активации. Бывает нескольких типов функции активации (рис. 3) [5].
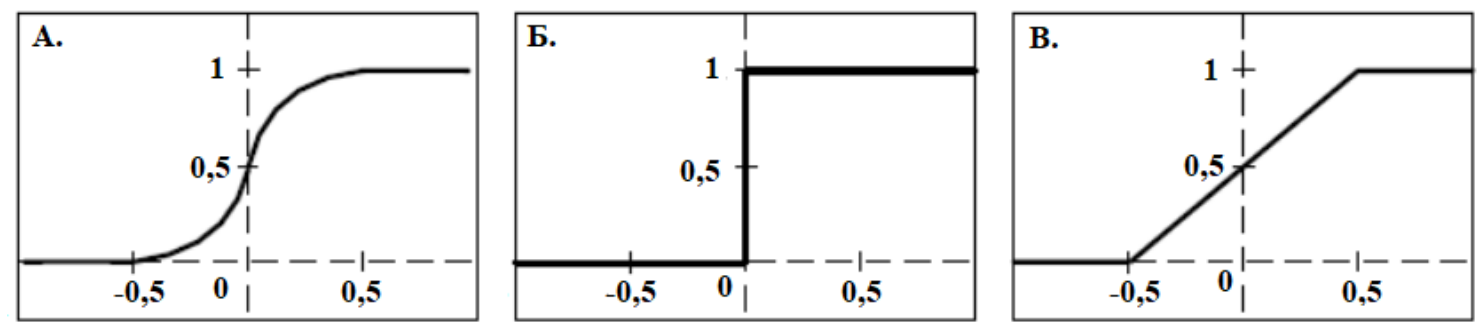

Рис 3. Сигмоидальная (а), пороговая (б) и линейная (в) функции активации нейрона

В искусственных нейронных сетях чаще всего используется нелинейная функция активации - сигмоидальная (2):

$$
\sigma(\mathrm{x})=\frac{1}{1+\exp (-\mathrm{tx})}
$$

Во избежание лишнего потребления памяти ПЛИС, применяется свойство симметрии пороговой функции. Таким образом, в памяти сохраняется 8000 двадцати шести разрядных значений первых $50 \%$ сигмоидальной функции и дополнительная логическая схема на базе сумматора для построения второй части.

Для реализации любой структуры необходимо обеспечить вероятность хранения численных величин. Разрядность этих величин определяет число возможных состояний каждого нейрона, а с учетом количества нейронов структуры в целом. Для этого можно сохранять выходное значение каждого нейрона в переменную типа reg. Так как каждый нейрон представляет собой модуль на языке Verilog, то можно возводить топологию сети, руководствуясь отдельными нейронами, и не углубляться до значений весов.

\section{Список использованных источников:}

1. В.С. Чумак, И.В. Свид. Перспектива использования продукта FPGA в медицинских системах. XIII Міжнародна науково-практична конференџія магістрантів та аспірантів «Теоретичні та практичні дослідження молодих науковцุів» (С. 288-289) 19-22 листопада 2019 року: м. Харків, Україна.

2. Oleg Zubkov, Iryna Svyd, Oleksandr Maltsev, Liliia Saikivska. In-circuit Signal Analysis in the Development of Digital Devices in Vivado 2018. First International Scientific and Practical Conference «Theoretical and Applied Aspects of Device Development on Microcontrollers and FPGAs»MC\&FPGA2019, (p. 12-13) July 26-27, 2019. Kharkiv, Ukraine.

3. В.С. Чумак, И.В. Свид. Современные тенденции подготовки технических специалистов. Сучасна освіта - доступність, якість, визнання: збірник наукових праць ХІ Міжнародної науковометодичної конферениії, (С. 245-247) 13-14 листопада 2019 року, м. Краматорськ, Україна.

4. Iryna Svyd, Oleksandr Maltsev, Liliia Saikivska, Oleg Zubkov. Review of Seventh Series FPGA Xilinx. First International Scientific and Practical Conference "Theoretical and Applied Aspects of Device Development on Microcontrollers and FPGAs» MC\&FPGA-2019, July 26-27, 2019. Kharkiv, Ukraine.

5. Безрук В.М., Свид І.В., Корсун І.В. (2008) Нейронні технологї̈ в телекомунікаціях та системах управління: навч. посібник с грифом МОН. - Харків: СМІТ 
Салім Максим Саламович, здобувач вищої освіти факультету електроніки Національний технічний університет України «Київський політехнічний інститут імені Ігоря Сікорського», Україна

\section{РОЗРОБКА ПРИЛАДУ КЕРУВАННЯ ОСВІТЛЕННЯМ В ПРИМНЩЕННЯХ}

Освітлення відіграє величезну роль в життєвому циклі людини. Від правильно підібраного освітлення залежить більшість біологічних процесів, які проходять в організмі людини. Все це доведено науковим шляхом. Також існує такий факт, що при природному сонячному освітленні людина більш активна, бадьора та життєрадісна. Негативний вплив світла на людину виражається у вигляді появи частої втомлюваності та сонливості. Іншими словами світло має колосальний вплив на поведінку нашого організму. Це пояснюється тісним взаємозв'язком освітлення та так званим внутрішнім біологічним годинником людини.

Ні для кого не секрет, що в сучасному світі людина проводить більшість часу під штучним освітленням, в основному на робочому місці[1]-[2]. В першу чергу під час трудового процесу відбувається втомлюваність очей, яка залежить від таких процесів як:

- Акомодація

- Адаптація

- Конвергенція

А так як майже вся частина інформації, яку сприймає людина, проходить через зоровий канал, то правильно підібране освітлення впливає на якість виконання всіх видів робіт. Відповідно при поганому чи неправильно підібраному освітленні людина працює погано, іiі продуктивність зменшується, помилок в роботі трапляється дедалі більше, а саме страшне - зростає потенційна небезпека виникнення нещасного випадку. Також неправильне освітлення на робочому місці може призвести до професійних захворювань, пов'язаних 3 зором. Найпопулярнішим таким захворюванням є короткозорість.

Проаналізувавши всю вище описану проблематику, пов'язану з освітленням в приміщеннях, було вирішено розробити прилад, який можна було б використовувати не тільки в побуті, але й на виробництві і т.д. для забезпечення будь яких потреб в освітленні. Прилад має бути простим у використанні та налаштуванні.

Структурна схема приладу зображена нижче (рис. 1):

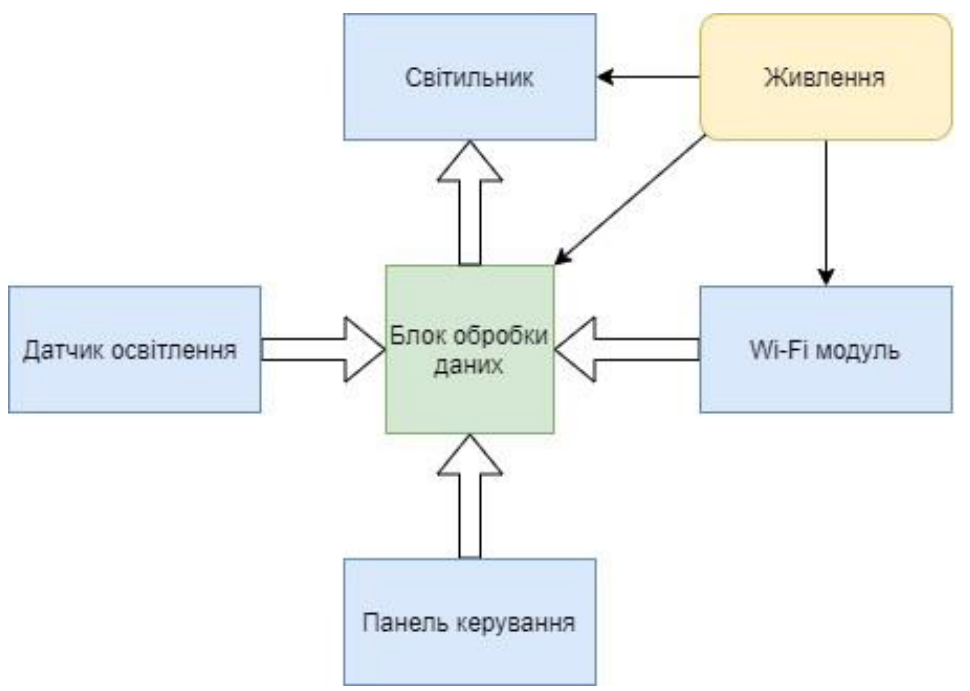

Рис 1. Структурна схема приладу 
Для розробки прототипу приладу використані наступні компоненти:

1. Блок обробки даних - відлагоджувальна плата DE2 SoC на основі програмованої логічної інтегральної схеми(скорочено ПЛІС) сімейства Cyclone II від Altera.

2. Датчик освітлення - модуль GY-302 на основі звичайного фоторезистору.

3. Панель керування - клавіатура, яка підключається по інтерфейсу PS/2[3].

4. Wi-Fi модуль - відлагоджувальна плата NodeMCU на основі мікроконтролеру ESP8266 від Espressif.

5. Світильник - світлодіодна $32 \times 32$ RGB матриця.

На даному етапі розроблено тільки прототип приладу з використанням готових відлагоджувальних плат. Надалі планується розробка друкованої плати, яка буде містити всю периферію для роботи, щоб в подальшому даний прилад можна було б використовувати наприклад як один з блоків системи “Розумний дім”[4] і т.д. Також планується розробка відповідного програмного забезпечення для комфортного керування пристроєм з смартфону чи іншого девайсу.

\section{Список використаних джерел:}

1. Значення світла для працездатності та здоров'я людини. (2016). Вилучено 3 https://studfile.net/preview/5597940/page:27/

2. Boyce, P. R. (2010). The impact of light in buildings on human health(review). Indoor and Built Environment, (1), 8-20. https://doi.org/10.1177/1420326X09358028

3. Chapweske, A. (1999). PS/2 Mouse/Keyboard Protocol. Retrieved from http://www.burtonsys.com/ps2_chapweske.htm.

4. Chen, J. (2020). What Is a Smart Home? Real Estate Investing. Retrieved from https://www.investopedia.com/terms/s/smart-home.asp.

DOI 10.36074/17.04.2020.v2.03

Буславець Денис Олександрович, провідний інженер Укргідроенерго, магістрант центру заочно-дистанційного навчання Харківський наиіональний університет міського господарства ім. О.М. Бекетова, Україна

Науковий керівник: Охріменко Вячеслав Миколайович, канд. техн. наук, доцент, доцент кафедри систем електропостачання та електроспоживання міст Харківський національний університет міського господарства ім. О.М. Бекетова, Украӥна

\section{ШЛЯХИ ОПТИМІЗАЦІЇ РОЗПОДІЛЬНИХ МЕРЕЖ ЗА РЕАКТИВНОЮ ПОТУЖНІСТЮ}

Серед важливих завдань проектування i експлуатації розподільних електричних мереж (РЕМ) $є$ зменшення втрат електричної енергії (ЕЕ). На думку багатьох дослідників [1, 2 та ін.] одним їз шляхів досягнення ефективності систем електропостачання є компенсація реактивної потужності (КРП).

Проблема КРП викликана значним завантаженням елементів розподільних мереж недоцільними потоками реактивної потужності (РП) внаслідок значного іiі споживання з мереж. Рішення проблеми можна отримати за рахунок забезпечення ефективного розподілу потоків РП в результаті оптимального завантаження існуючих джерел РП та встановлення компенсуючих пристроїв (КП) у мережах електроспоживачів і у проблемних за напругою вузлах мережевих компаній. Оптимальні рішення щодо компенсації РП на різних рівнях напруги розподільної 
мережі дозволяють домогтися таких результатів: знизити втрати ЕЕ, нормалізувати рівні напруг, підвищити режимну керованість розподільної мережі.

Зниження втрат ЕЕ вважається найважливішим завданням і реальною експлуатаційною технологією енергозбереження, a ефективне економічне регулювання перетоків РП - одна з важливих проблем електроенергетики, яка набуває особливої актуальності у зв'язку 3 введенням нових нормативних документів в частині умов споживання РП. В даний час головне значення має не деталізація вимог по оплаті РП конкретним споживачем з урахуванням параметрів $(\operatorname{tg} \varphi)$ точки приєднання до мережі, а розроблення алгоритмів вибору оптимальної потужності і місць улаштування джерел РП, завантаження КП на основі усієї сукупності станів розподільної мережі, яка визначається в основному чинником багаторежимності і стохастичним характером вихідної інформації.

Метою даної роботи було дослідження стану питання щодо шляхів оптимізації режиму розподільних мереж за реактивною потужністю.

Підвищене споживання РП за умови постійного активного навантаження характеризується зниженим значенням коефіцієнта потужності $\cos \varphi$ (або підвищеним значенням коефіцієнта реактивної потужності $\operatorname{tg} \varphi$ ), що в загальному випадку трактується як погіршення даного показника і, відповідно, стану об'єкта електричної мережі по РП.

Передача РП по електричних мережах (рис. 1) призводить до ряду негативних наслідків [3, 4].

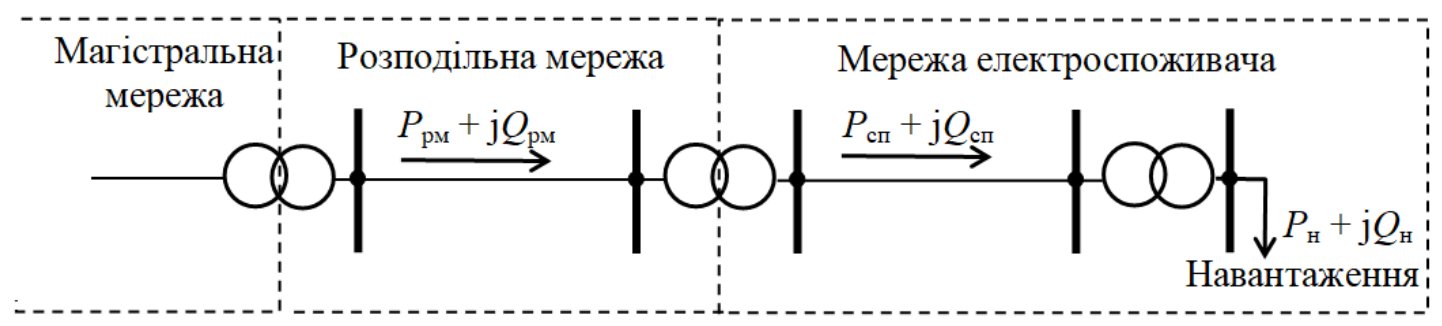

Рис. 1. Передача реактивної потужності електричною мережею

1. Зростає струм, що протікає ділянками мереж:

$$
I=\frac{\sqrt{P^{2}+Q^{2}}}{\sqrt{3} \cdot U}=\frac{P \sqrt{1+\operatorname{tg}^{2} \varphi}}{\sqrt{3} \cdot U} .
$$

Зростання потоків РП в міжсистемних, системоутворюючих електричних мережах і системах розподілу ЕЕ призводить до збільшення до гранично припустимих значень струмів нормального режиму роботи ЛЕП $\mathrm{i}$ трансформаторних підстанцій. 3'являється необхідність збільшення площі перерізу проводів, числа i потужності трансформаторів, що веде до подорожчання капітального будівництва, ремонту і реконструкції електромережних об'єктів. Також прискорюються старіння і знос основних фондів.

2. Збільшуються втрати напруги $\Delta U$ в електричних мережах:

$$
\Delta U=\frac{P \cdot R+Q \cdot X}{U}=\frac{P(R+\operatorname{tg} \varphi \cdot X)}{U} .
$$

Зростання втрат напруги призводить до зниження напруги на шинах підстанцій РЕМ і в навантажувальних вузлах, зменшення радіусу дії мережі, зниження запасу за статичною стійкістю вузлів систем електропостачання та вузлів навантаження за напругою. Збільшується число випадків вимикання споживачів $\mathrm{i}$ розміри навантажень, що вимикаються релейним захистом при зниженні напруги під 
час коротких замикань i циклів автоматичного повторного вмикання або автоматичного введення резерву в електричних мережах.

3. Відбувається обмеження пропускної здатності електричних мереж за активною потужністю у наслідок їх необгрунтованого завантаження реактивною потужністю. 3'являється необхідність прокладання нових мережевих магістралей, що передбачає додаткові капіталовкладення.

4. Збільшуються втрати активної потужності і EЕ (за період часу Т) в електричних мережах:

$$
\Delta P=\frac{P^{2}+Q^{2}}{U^{2}} R=\frac{P^{2}\left(1+\operatorname{tg}^{2} \varphi\right)}{U^{2}} R ; \quad \Delta E=\int_{0}^{T} \Delta P(t) d t .
$$

Відбувається перевитрата EE і значно погіршується техніко-економічна ефективність електромережевого бізнесу.

5. Штучно викликаний дефіцит активної потужності в ряді вузлів і районів РЕМ призводить до неможливості здійснювати приєднання нових електроспоживачів або збільшення встановленої виробничої потужності.

Великі потоки РП ділянками мереж усіх рівнів напруги роблять розподільні мережі надмірно чутливими до збурень і нестійкими навіть при незначних збуреннях. Це одна з основних причин відмов в РЕМ.

У даній роботі розглянуті електричні мережі напругою 6 - 110 кВ, що виконують функцію розподілу електричної енергії. РЕМ становлять найбільш масову і розгалужену частину електричних мереж і концентрують в собі близько 78\% загальної величини технічних втрат електроенергії [2].

Тим часом зниження втрат ЕE вважається найважливішим завданням i реальної експлуатаційної технології енергозбереження. У процесі експлуатації РЕМ проблему вирішують шляхом встановлення КП у вузлах розподільної мережі і у місцях споживання РП (рис. 2).

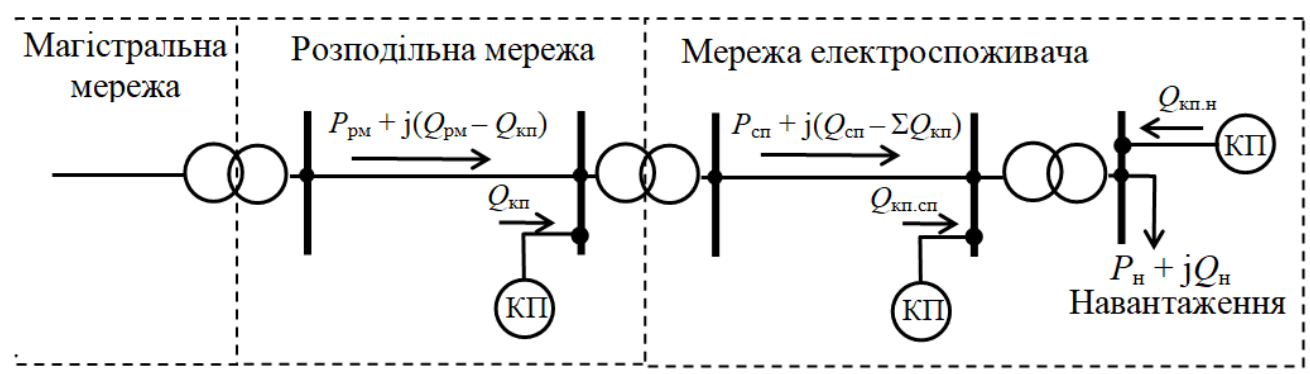

\section{Рис. 2. Компенсація реактивної потужності}

Рішення проблеми компенсації РП дозволяє отримати істотні результати, а саме $[3,4]$ :

- підвищити надійність роботи систем передачі і розподілу ЕЕ і стійкість навантаження при зниженні і провалах напруги у мережі;

- поліпшити техніко-економічні показники систем електропостачання електромережних компаній і споживачів;

- нормалізувати рівні напруг у РЕМ;

- знизити втрати ЕЕ за рахунок нормалізації напруги і зменшення струмів реактивної потужності;

- приєднати нових споживачів в вузлах 3 КРП, збільшити виробничі потужності без збільшення споживання з мережі.

Проблема оптимальної КРП в системах розподілу ЕЕ повинна вирішуватися комплексно як на рівні мережевих організацій, так і на рівні споживачів ЕЕ. Основні практичні дії щодо ії вирішення такі: 
- на рівні споживачів EЕ - встановлення в мережах споживачів КП на напругах $0,38,6,10(20)$ кВ;

- на рівні мережевих компаній - встановлення джерел РП в найбільш проблемних за напругою вузлах РЕМ 35-110 кВ.

При цьому неминуче виникають наступні питання.

1. В яких вузлах необхідно встановити КП, джерела РП?

2. Які потужності прийняти для нових чи завантажити встановлені КП, джерел РП, щоб відповідно сумарні розрахункові витрати або втрати ЕЕ в мережі стали мінімальними?

3. За яким графіком повинні працювати КП, джерела РП, щоб економічний ефект від компенсації був найбільшим?

Дані питання $є$ визначальними при вирішенні поставленого завдання оптимальної компенсації РП.

Як КП, джерела РП можуть використовуватися батареї статичних конденсаторів (БСК), статичні тиристорні компенсатори і синхронні компенсатори. 3 огляду на економічність у системах розподілу ЕЕ в основному використовуються БСК.

У даний час вибір джерел РП та КП в розподільних мережах ведеться для вирішення локальних завдань (гранично низькі напруги у вузлах, необхідність збільшення пропускної здатності мережі та ін.). Досить часто цей вибір не $\epsilon$ оптимальним.

Таим чином, розроблення методик та алгоритмів оптимального вибору джерел РП, КП в системах розподілу ЕЕ з урахуванням усієї сукупності режимів на заданому інтервалі часу являє собою складну комплексну задачу, спрямовану на вирішення проблеми КРП, реалізація якої передбачає три основні частини.

1. Вибір підходу до формування цільової функції розрахункових витрат на спорудження, експлуатацію та обслуговування джерел РП, КП, втрати ЕЕ в мережі.

2. Аналіз розроблених методів оптимізації і вибір найбільш ефективного.

3. Вибір методу обліку багаторежимності для визначення інтегральних характеристик, перш за все втрат ЕE, що задовольняє вимогам точності i достовірності.

\section{Список використаних джерел:}

1. Ушаков В.Я. (2013). Современные проблемы электроэнергетики. Томск: Изд-во Томского политехнического университета, 448. Вилучено 3: https://portal.tpu.ru/files/personal/ushakov/01.pdf.

2. Кузьмин В. В., Кирисов И. Г. \& Малинин С. В. (2012). Анализ средств компенсации реактивной мощности в электрических сетях Украины. Энергосбережение. Энергетика. Энергоаудит. 5(99), 45 50. Вилучено 3: http://nbuv.gov.ua/UJRN/ecee_2012_5_8.

3. Железко Ю. С. (2009) Потери электроэнергии. Реактивная мощность. Качество электроэнергии: руководство для практических расчётов. Москва: ЭНАС, 456. Вилучено 3: https://www.c-ok.ru/library/document/13270.

4. Герасименко, А. А., \& Нешатаев, В. Б. (2011). Методика и алгоритм расчёта потерь электрической энергии в задаче оптимальной компенсации реактивной мощности в распределительных сетях электроэнергетических систем. Журнал Сибирского федерального университета. Техника и технологии, 4 (5), 567-591. Вилучено 3: https://cyberleninka.ru/article/n/metodika-i-algoritm-raschyotapoter-elektricheskoy-energii-v-zadache-optimalnoy-kompensatsii-reaktivnoy-moschnosti-v-raspredelitelnyh. 


\section{СЕКЦІЯ 3. ФІЗИКО-МАТЕМАТИЧНІ НАУКИ}

Кирпель Павло Станіславович, магістрант 1 го року навчання спеціальності 104 Фізика та астрономія Національний педагогічний університет імені М.П. Драгоманова, Україна

Науковий керівник: Кириленко О.І., кандидат педагогічних наук, доцент кафедри експериментальної і теоретичної фізики та астрономії Національний педагогічний університет імені М.П. Драгоманова, Украӥна

\section{КОСМІЧНІ ПРОМЕНІ В ЖИТТІ ЛЮДЕЙ}

Колись вас спитають - «А що було тоді, коли ти починав свій шлях?».

I ви не будете знати, напевно, що відповісти, адже було одночасно стільки всього фантастичного та неймовірного. Кожен день дарував нові відкриття та чудасії. А може згадаєте про небо та подумаєте, а що ж було там. Та почнеться велична історія з красивими барвами, зорями, планетами, чорними дірами та вперше поміченою зорею на небі. Так буде і про космічні промені, що сягають безмежних просторів, та наших з вами минулих та майбутніх днів.

Взагалі, космічні промені - це потоки високоенергетичних протонів, ядер і електронів.

Космічні промені вперше були відкриті в 1912 році. Це зробив австрійський фізик Віктор Гесс. Він був співробітником Радієвого інституту Відня і проводив дослідження іонізованих газів. На той час вже знали, що всі гази (i атмосфера у тому числі) завжди, злегка, іонізовані, що свідчило про присутність радіоактивної речовини (подібної до радію) або у складі газу, або поблизу приладу, що вимірює іонізацію, найімовірніше - в земній корі.

Для того щоб перевірити це припущення було вирішено зробити дослід: на повітряній кулі підняти в небо прилад, що реєструє іонізацію. В теорії мало вийти, що 3 підйомом кулі іонізація має зменшуватися. Оскільки вона віддаляється від джерела іонізації. Проте, під час експерименту були отримані зовсім інші результати. 3 підняттям кулі на все більшу висоту, детектор фіксував все більшу кількість випромінення, причому його інтенсивність все більше зростала. Це навело Геса на думку, що має існувати випромінення, яке приходить на Землю не 3 мінералів, а з космічного простору. Проте остаточно довести наявність позаземного випромінення вдалося лише через певний час, та велику кількість дослідів.

За ці дослідження в 1936 році Гесс отримав нобелівську премію.

Цікаво, що космічне випромінення хоч так і називається, але променів як таких там не існує загалом. Термін "випромінення" не означає, що ці промені мають чисто електромагнітну природу (як сонячне світло, радіохвилі або рентгенівське випромінення); його використовували при відкритті явища, природа якого ще не була відома. I хоча незабаром з'ясувалося, що основні компоненти космічних променів - прискорені заряджені частки, протони, термін зберігся.

У 1948 році за допомогою ядерних фотографічних емульсій, було виявлено склад космічних променів. Оскільки, при дослідженні первинних космічних променів були виявленні сліди більш важких ядер, ніж водень. В продовж дослідження космічних променів, було виявлено багато нових частинок. Наприклад: позитрон, мюон, пі-мезон, К-мезон, Л-гиперон. 
У 1932 р. П. Блекетт і Дж. Оккіаліні вперше виявили в камері Вільсона групи близьких за напрямком генетично зв'язаних часток космічного випромінення - так звані зливи. У дослідах 1945-1949 рр. на високогірних станціях космічних променів (В.I. Векслер, Н.А. Добротін та ін.) і в стратосфері (С.Н. Вернов та ін.) було встановлено, що вторинне космічне випромінення утворюється в результаті взаємодії первинних космічних променів з ядрами атомів повітря. Пізніше Георгій Тимофійович Зацепін показав, що той же механізм, але при вищих енергіях $\left(10^{14} \mathrm{eB}\right)$ пояснює розвиток відкритих раніше в космічних променях (П. Оже, 1938) широких атмосферних злив - потоків з багатьох мільйонів часток, що покривають на рівні моря площі близько 1 км$^{2}$ і більш.

Для успішного виявлення космічних променів велику роль зіграли в свою чергу радіоастрономи. Оскільки, пов'язане з космічними променями нетеплове космічне радіовипромінення дозволило виявити їх можливі джерела. У 1955 р. В.Л. Гинзбург і I.C. Шкловський на основі астрономічних для радіо спостережень і енергетичних оцінок, вперше кількісно обгрунтували гіпотезу про найновіші зорі як одному з основних галактичних джерел космічних променів.

Базою для космофізичного напряму досліджень з'явилася створена в 50-60-і рр. обширна світова мережа станцій космічних променів (понад 150), на яких проводиться безперервна реєстрація космічного випромінення. Багато станцій знаходяться високо в горах, на деяких станціях проводяться підземні спостереження, регулярно посилаються в стратосферу балони 3 приладами автоматичної реєстрації космічних променів.

Нові можливості прямого вивчення первинних космічних променів в дуже широкому діапазоні енергій відкрилися у зв'язку з підйомом реєструючої апаратури на штучних супутниках Землі і міжпланетних автоматичних станціях. Зокрема, за допомогою калориметра іонізаційного на супутниках серії "Протон" був вперше безпосередньо виміряний енергетичний спектр первинних космічних променів до енергії $10^{15}$ еВ (радянський фізик Н.Л. Григоров та ін., 1965 - 1969 рр.). Пізніше за допомогою штучних супутників «Луни» i «Марса», а також на радянському «Луноходе-1» (1970-1971 рр.) були проведені тривалі виміри варіацій складу та інтенсивності космічних променів, за межами магнітосфери Землі.

Природа космічного випромінення виявилася дуже складною. Лише у п'ятдесятих роках, спираючись на результати багаточисельних досліджень, серед яких видне місце займають роботи школи радянського фізика Д.В. Скобельцина, удалося скласти відоме уявлення про картину цього явища вцілому. За сучасними уявленнями первинне космічне випромінення, тобто випромінення, що приходить зі світових глибин в земну атмосферу, складається 3 швидко рухомих позитивно заряджених часток - протонів і в меншому числі - бетачасток та інших ядер. Енергія первинних часток космічного випромінення величезна, вона вимірюється мільярдами еВ, а в деяких випадках доходить навіть до фантастичних значень $10^{21} \mathrm{eB}$; при цьому: чим більше енергія частки, тим менше зустрічається таких часток в первинній компоненті. Відносно механізму прискорення, шляхом якого у Всесвіті утворюються частки такої величезної енергії, існує ряд припущень, дослідження яких продовжується.

3 первинного космічного випромінення лише мала доля доходить до поверхні Землі. Переважна частина первинних часток ще у верхніх шарах атмосфери стикається з ядрами атомів, що входять до складу повітря. Зважаючи на величезну енергію первинних часток такі зіткнення наводять до розщеплювання атомних ядер 3 випусканням швидких нейтронів, протонів і $\alpha$-часток. Крім того, зіткнення часток великої енергії з ядрами супроводжуються утворенням нових часток - різних мезонів 
і гіперонів. Залежно від вигляду гіперони перетворюються на мезон і нуклон (нейтрон або протон). Мезони перетворюються кінець-кінцем на електрони, позитрони або $\gamma$ - кванти.

Отже, в результаті зіткнення швидкої первинної частки 3 атомним ядром утворюється значна кількість вторинних часток меншої енергії - протонів, нейтронів, $\alpha$-часток, різних гіперонів і мезонів, електронів, позитронів, $\gamma$-квантів. Вторинні частки, просуваючись, в атмосфері, у свою чергу розмножуються за рахунок ядерних розщеплювань та інших процесів, прикладом яких служить утворення електронно-позитронних пар $\gamma$-квантами.

Разом 3 розмноженням часток в атмосфері відбувається їх поглинання, аналогічно тому, як відбувається поглинання $\alpha-, \beta$ - i $\gamma$ - частинок при проходженні через речовину. У верхніх шарах атмосфери переважаючим процесом $\epsilon$ розмноження, і число часток космічного випромінення наростає аж до висоти $\sim 20$ км над рівнем моря. Нижче за цей кордон, головну роль грає поглинання та інтенсивність випромінення падає.

На висотах вище 50 км присутня лише первинна компонента космічного випромінення, що приходить зі світового простору та інтенсивність випромінення не залежить від висоти. Нижче 50 км інтенсивність спочатку збільшується за рахунок утворення вторинних часток, а потім падає за рахунок зростаючого поглинання в атмосфері.

По своєму походженню космічні промені можна розділити на декілька груп:

1) космічні промені галактичного походження. Джерелом галактичних космічних променів $є$ наша Галактика, в якій відбувається прискорення часток до енергій $\sim 10^{18} \mathrm{eB}$;

2) космічні промені походження метагалактики, вони мають найбільші енергії, $\mathrm{E}>10^{18} \mathrm{eB}$, утворюються в інших галактиках;

3) сонячні космічні промені, що генеруються на Сонці під час сонячних спалахів;

4) аномальні космічні промені, що утворюються в Сонячній системі на периферії геліомагнітосфери.

Також існує думка, що космічні промені можуть впливати на роботу сучасної техніки, а особливо на смартфони. В цьому звичайно щось $\epsilon$, але чи це правда треба ще розбиратися і розбиратися.

\section{Список використаних джерел:}

1. Електроний ресурс // Режим доступу: https://tsn.ua/nauka_it/astronomi-znayshli-dzherelokosmichnogo-viprominyuvannya.html

2. Електроний ресурс // Режим доступу:https://collectedpapers.com.ua/ru/the-cosmic-microwavebackground/kosmichni-promeni-ta-reliktove-viprominyuvannya

3. Електроний ресурс // Режим доступу:https://kaf-rt.tntu.edu.ua/uk/articles/ kosmichni-promenimozhut-vyvodyty-z-ladu-samrtfony

4. Електроний ресурс // Режим доступу: https://knowledge.allbest.ru/air/ 2c0a65625b3bc78b5c43a88421206c37_0.html 
Скібчик С.А., студентка

Національний університет біоресурсів та природокористування Украӥни, Украӥна

Науковий керівник: Артемчук Л.М., доцент кафедри вищої математики

Національний університет біоресурсів та природокористування Украйни, Украӥна

\section{МАТЕМАТИЧНЕ МОДЕЛЮВАННЯ}

Моделювання включає створення, дослідження та використання моделей об'єктів. Методи моделювання широко використовуються в різних сферах людської діяльності, особливо в сферах проектування і управління, де основними є процеси ухвалення ефективних рішень на основі інформації, що отримується. Метою моделювання є здобуття, обробка, представлення і використання інформації про об'єкти, які взаємодіють між собою і зовнішнім середовищем.

Теорія моделювання $є$ розділом науки, що вивчає способи дослідження властивостей об'єктів на основі заміщення їх іншими об'єктами . Вирізняють натурні, фізичні, мовні та математичні моделі.

Зупинимося на одному 3 найбільш універсальних видів моделювання математичному, що ставить у відповідність модельованому фізичному процесу систему математичних співвідношень, вирішення якої дозволяє отримати відповідь на питання про поведінку об'єкту без створення фізичної моделі, яка часто є дорогою i малоефективною. Отже, математичною моделлю називається сукупність математичних співвідношень, рівнянь, нерівностей, що описують основні закономірності, властиві досліджуваному процесу, об'єкту або системі.

Математичні моделі, особливо ті, що використовують чисельні методи, потребують для свого створення значних інтелектуальних, фінансових та часових затрат. Тому рішення про створення нової моделі приймається лише в разі відсутності більш простих шляхів вирішення поставленої проблеми.

Дослідження об'єкту моделювання і складання його математичного опису полягають у встановленні зв'язків між характеристиками процесу, виявленні його граничних і початкових умов та формалізації процесу у вигляді системи математичних співвідношень.

В деяких випадках дослідження внутрішньої будови та порядку функціонування об'єкта моделювання неможливе або економічно недоцільне. Тому можливо розглядати об’єкт як „чорний ящик”, стосовно якого нам відомі лише його входи та виходи.

На підставі аналізу об'єкту моделювання формується змістовна постановка моделювання, в якій мають бути зазначені: мета моделювання; тип моделі;вимоги до адекватності моделі та якості розв'язку.

Математична постановка задачі моделювання - це сукупність математичних співвідношень, які описують поведінку та характеристики об'єкта моделювання. Необхідно формалізувати змінні моделі та зв'язки між ними. Математичний опис моделі складається на основі законів фізики, хімії тощо, які характеризують динаміку і статику процесів в досліджуваному об'єкті, і виражається на мові будьяких розділів математики. Найбільше поширення при побудові детермінованих моделей набули алгебраїчні рівняння та системи, звичайні диференціальні рівняння i диференціальні рівняння в частинних похідних, матрична алгебра, а при стохастичному моделюванні і методи теорії імовірності, математичної статистики та теорії випадкових процесів.

Поняття коректності задачі має важливе значення в процесі моделювання. Адже, наприклад, чисельні методи розв'язку задач доцільно застосовувати лише до коректно поставлених задач. При цьому, не всі практичні задачі можна вважати 
коректними. Математична модель $є$ коректною, якщо для неї отримано позитивний результат по всіх контрольних перевірках: розмірності, порядку, характеру залежностей, граничних умов, фізичного сенсу тощо.

Для математичної моделі обирається один з методів розв'язку, який дозволяє при заданих значеннях вхідних змінних отримати значення вихідних змінних. Вибір методу обгрунтовується на підставі властивостей моделі, даних про точність вимірювання значень змінних, вимог до точності та швидкості отримання розв'язку.Необхідною умовою для переходу від дослідження об'єкта до дослідження моделі і подальшого перенесення результатів на об'єкт моделювання $\epsilon$ вимога адекватності моделі об'єкту.

Адекватність моделі визначається на підставі статистичних оцінок розбіжностей значень вихідних змінних моделі та об'єкту при однакових значеннях вхідних змінних, розрахованих за результатами серії експериментів на об'єкті моделювання. Для перевірки адекватності моделі використовуються дані іншої серії експериментів, ніж для параметричної ідентифікації.Після успішної перевірки адекватності модель може бути застосована в задачах прогнозу та дослідження об'єкта.

Метод математичного моделювання дозволяє виключити необхідність виготовлення громіздких фізичних моделей, пов'язаних з матеріальними витратами; скорочувати час визначення характеристик; вивчати поведінку об'єкту моделювання при різних значеннях параметрів; аналізувати можливість застосування різних елементів; отримувати характеристики і показники, які складно отримувати експериментально.

\section{Список використаних джерел:}

1. Фізико-математичне моделювання та інформаційні технології: Наук. зб. вип. 12 ім. Я. Підстригача НАН України, 2010, с. 76-188.

2. Папушин Ю. Л., Смирнов В. О., Білецький В. С. Дослідження корисних копалин на збагачуваність (навчальний посібник). Донецьк: Східний видавничий дім, НТШ-Донецьк - 2006,с. 182 .

Куценко Тетяна Янівна, магістрант 1-го року навчання спеціальності 104 Фізика та астрономія

Національний педагогічний університет імені М.П. Драгоманова, Украӥна

Науковий керівник: Тартачник В. П., доктор фізико-математичних наук, професор Національний педагогічний університет імені М.П. Драгоманова, Украӥна

\section{СОНЯЧНІ ЕЛЕМЕНТИ}

На сьогодні у зв'язку з інтенсивним розвитком енергоспоживання актуальною залишається проблема використання альтернативних джерел. У багатьох країнах перехід на альтернативні джерела відбувається достатньо стрімко, що особливо це стосується сонячної енергетики.

Для отримання електричного струму у подібних пристроях використовується енергія Сонця - потужність потоку сонячного випромінювання на один квадратний метр становить приблизно 1350 Вт. Найпростіший напівпровідниковий сонячний елемент містить області з різним типом провідності.

У більшості випадків він виготовляється з додаванням потрібних домішок, завдяки чому виникає $\mathrm{p}$ - $\mathrm{n}$ - перехід: одна область із надлишком валентних електронів, інша - дірок. На контакті виникає збіднена область. Цей шар протидіє 
переходу надлишкових електронів 3 шару “n” у шар “p”, де електронів не вистачає. Якщо під'єднати до такої структури джерело живлення, зовнішнє електричне поле змусить електрони подолати бар'єр; через провідник потече струм.

Подібний процес спостерігається також при дії сонячного випромінювання. Фотон проникаючи у напівпровідник передає свою енергію електронам, котрі вивільняються; на їхньому місці з'являється дірка. При наявності зовнішнього поля електрони вільно долають збіднену область напівпровідника і переходять 3 шару “p” у шар “n”, дірки рухаються у зворотному напрямку. Результатом переміщення зарядів буде виникнення у напівпровіднику різниці потенціалів.

Сила струму генерованого сонячним елементом, змінюється пропорційно числу захоплених поверхнею елемента фотонів.

Існує два види сонячних панелей:

- жорсткі (каркасні), гнучкі або тонкоплівкові;

- одно- або двосторонні.

За технологією виготовлення і використаних матеріалів їх ділять на дві великі категорії:

1. Кремнієві. Вони поширеніші, ніж плівкові. Що пояснюється поширеністю кремнію у земній корі, великою кількістю виробників, високим ККД і простішою технологією виготовлення.

2. Плівкові. Для них характерна нижча продуктивність і вартість.

3. Телуридо-кадмієві. Вони виготовляються на основі телуриду кадмію. Раніше ця технологія використовувалася тільки у космонавтиці, наразі вони доступні для широкого кола споживачів. Хоча ККД подібних фотопанелей раніше був невисоким, в останніх моделей він наближається до $18 \%$.

4. Селено-індієво-мідні. Індій замінюється галієм, що дає можливість підвищити ККД до 14\%.

5. Полімерні. Мають невеликий ККД (лише 6\%), але внаслідок невисокої вартості користуються популярністю і вважаються доступнішими.

6. Монокристалічні кремнієві сонячні елементи. Для їх виробництва $\mathrm{Si}$ обробляють за технологією, польського хіміка Чохральського. Технологія виробництва достатньо дорога, але вона компенсується високим ККД модулів (в межах 18-22\%).

7. Полікристалічні. Виготовляють шляхом повільного охолодження сплаву, основу якого складає кремній. Дана технологія, на відміну від монокристалічних, вимагає значно менших енерговитрат, тому собівартість даного виду сонячних панелей $є$ дещо нижчою. Однак їхній ККД - менший.

8. Панелі з аморфного кремнію. Це гібридний підвид, оскільки для їхнього виготовлення теж використовується $\mathrm{Si}$, але за тонкоплівковою технологією. Вони мають найнижчий ККД (приблизно 6\%), але, тим не менш, користуються великою популярністю завдяки високому показнику оптичного поглинання, ефективній продуктивності при низькій яскравості сонячного світла та малій товщині пластини.

Типові панелі складаються з фотоелектричних селів, процес виробництва яких, починається 3 виділення Si з піску чи кварцу. На першому етапі отримують так званий металевий кремній. $\mathrm{I}_{3} \mathrm{SiO}_{2}$ шляхом плавлення з використанням вуглецю в печі електродуги отримують металевий кремній з чистотою 99\%. Для виготовлення сонячних комірок необхідний кремній з чистотою 99.9999\%.

Процес очищення протікає всередині великих вакуумних камер, де кремній осідає на тонкі полікремнієві стрижні. Він вперше розроблений компанією Siemens в 60-х роках і часто згадується, як процес Siemens. Для досягнення високої чистоти 
необхідні значні енергозатрати, очищення супроводжується великою кількістю відходів - на кожну тонну чистого кремнію припадає 4 тонни відходів.

Виробництво кремнію з полікристалічною і монокристалічною структурою два технологічно різних процеси. Монокристалічний кремній вирощується із невеликого за розміром кристала, який повільно витягується 3 розплаву полікремнію. Це вимагає великих енергетичних витрат. Однак, одержуваний матеріал володіє цілим рядом властивостей і характеристик, які не можна отримати при виробництві матеріалу з полікристалічної структурою:

- високий ККД отриманого матеріалу;

- низька деградація за рахунок використання високоякісного кремнію;

- менший ступінь риску розтріскування.

Полікристалічний кремній отримують шляхом плавлення у прямокутній формі, отже виріб складається з окремих кристалів кремнію. На наступному етапі заготовка розрізається багатодротовою пилкою на тонкі пластини. Після обробки і нанесення металевих контактів формується фотоелектрична комірка і заготовка розрізається.

Джерела енергії подібного типу використовуються для космічних апаратів тривалого використання, де сонячні елементи(батареї) служать єдиним безальтернативним джерелом енергії.

Підсумовуючи, відмітимо, що сонячні елементи - один із найперспективніших джерел енергії головним чином, внаслідок високої екологічної “чистоти”.

\section{Список використаних джерел:}

1. Плачкова, С. Г. Энергетика. История, настоящее и будущее. Книга 5. Электроэнергетика и охрана окружающей среды. Функционирование энергетики в современном мире / С. Г. Плачкова // [Електронний ресурс]. - Режим доступу: http://energetika.in.ua/ru/books/book-5

2. Методичні вказівки та завдання до виконання розрахунково - графічної роботи $з$ дисципліни «Фізико-технологічні основи перетворення сонячної енергії» / укладачі А. С. Опанасюк, О. А. Доброжан. - Суми : Сумський державний університет, 2016. - 37 с. 


\section{СЕКЦІЯ 4. ХІМІЧНІ НАУКИ}

Образенко А.Ф., студент I курсу другого (магістерського) рівня вищої освіти, природничо-географічний факультет

Центральноукраїнський державний педагогічний університет імені Володимира Винниченка, Україна

Науковий керівник: Бохан Ю.В, к.Х.н., доцент, доцент кафедри природничих наук та методик їхнього навчання

Центральноукраїнський державний педагогічний університет імені Володимира Винниченка, Україна

\section{ЛАБОРАТОРНО-ХІМІЧНА ЕКСПЕРТИЗА ЯКОСТІ ПАСТЕРИЗОВАНОГО КОРОВ'ЯЧОГО ПИТНОГО МОЛОКА}

Молоко є продуктом високої біологічної цінності. Зі складових частин молока особливе значення має білок, який за амінокислотним складом $є$ повноцінним і має високу засвоюваність. Молоко складається з води (до $88 \%$ від загального обсягу) i сухого залишку (жир, білки, молочний цукор, мінеральні солі, мікроелементи, азотисті речовини, вітаміни, ферменти, гормони). Жир молока містить біологічноактивні жирні кислоти і $є$ джерелом вітамінів А і В. Мінеральні речовини в молоці представлені кальцієм, фосфором, які знаходяться в ньому у вигляді неорганічних солей, що легко засвоюються організмом. 3 хімічної точки зору молоко - це полідисперсна система, що включає в себе речовини, що знаходяться в різних станах: іонно-молекулярному (лактоза, мінеральні солі), колоїдному (фосфат кальцію, білки) і грубодисперсному (жир). Тобто, всі складові молока знаходяться в розчиненому вигляді. При недотриманні технологічних режимів, порушенні санітарно-гігієнічних умов виробництва, обробки й транспортування молоко та молочні продукти не лише втрачають свою поживну цінність, а й можуть бути небезпечними для здоров'я споживачів.

В Україні якість молока регулює ДСТУ 3662-97 «Молоко коров’яче незбиране. Вимоги при закупівлі», ДСТУ 2661-94 Молоко коров'яче питне. Загальні технічні умови [1-3]. Їх вимоги значно поступаються вимогам ЄС до якості та безпечності молока. В Україні на молокопереробні підприємства переважно надходить молоко першого та другого гатунків. У розвинутих країнах таке молоко не приймають на переробку. У застарілості ДСТУ та невідповідності його міжнародним стандартам якості [4] полягає, на наш погляд, першопричина низької якості вітчизняного молока та продуктів його переробки. Варто звернути увагу на те, що в Україні не контролюється точка замерзання молока, тільки густина. Цей показник дає змогу встановити факт фальсифікації молока. Оскільки останніми роками почастішали такі випадки, а ефективний метод визначення фальсифікації залишається поза контролем держави, на молокопереробні заводи часто надходить фальсифіковане молоко, що призводить до невідповідності виробленої з нього молокопродукції вимогам якості та безпечності. Таким чином, ця прогалина у державному контролі $\epsilon$ ще однією причиною низької якості вітчизняної молокопродукції. 
Мета роботи - провести порівняльну гігієнічну оцінку питного пастеризованого коров'ячого молока, що реалізується у торгівельний мережі м.Кропивницького. Комплексна порівняльна гігієнічна оцінка молока і молочної продукції проведена за наступними показниками: органолептичні показники (зовнішній вигляд, консистенція, смак і запах, колір, сторонні включення), масова частка білка, масова частка вологи, масова частка вологи в знежиреному речовині, масова частка жиру, масова частка жиру в перерахунку на суху речовину, сухий знежирений молочний залишок, масова частка сахарози, кислотність, кислотність жирової фази, титруєма кислотність плазми, перекисне число, густина тощо.

Для аналізу продукції нами було відібрано чотири зразки питного пастеризованого коров'ячого молока, що мали на упаковці запис про пастеризацію. Чотири зразки питного пастеризованого коров'ячого молока українських виробників були обрані з майже однакової цінової категорії (від 20,00 грн до 28,60 грн): зразок №1 - молоко коров’яче, торгівельна назва «Простоквашино» питне, пастеризоване; $1 \%$ - жирність; зразок №2 - молоко коров’яче, торгівельна назва «Яготинське» питне, пастеризоване; 1\% - жирність; зразок №3 - молоко коров’яче, торгівельна назва «Слов'яночка» питне, пастеризоване; 2,5\% - жирність; зразок №4 - молоко коров'яче, торгівельна назва «АТБ - Спецзамовлення» питне, пастеризоване; $2,6 \%$ - жирність.

Всі дослідження були виконані на базі лабораторії кафедри природничих наук та методик їхнього навчання Центральноукраїнського державного педагогічного університету імені В. Винниченка. Деякі результати проведених лабораторнохімічних досліджень якісних показників питного пастеризованого коров'ячого молока українських виробників представлені нижче.

При дослідженні органолептичних показників зразків молока встановлено, що за зовнішнім виглядом всі досліджувані зразки представляли собою непрозору рідину, по консистенції - рідку, однорідну, не тягучу рідину, без пластівців білка і збитих грудочок жиру. Досліджувані зразки мали білий рівномірно забарвлений колір, запах властивий для молока, без сторонніх запахів, з легким присмаком, характерним для даного виду продукції. За органолептичними показниками всі досліджувані зразки молока відповідали вимогам нормативного документа.

Під час фальсифікації якість молока, як єдиної фізико-хімічної системи, значно змінюється, що пояснюється властивостями складових. Оскільки змінюються і склад, і стан компонентів молока, відповідно змінюватимуться і його фізико-хімічні властивості, наприклад густина. Густина молока залежить від його компонентів, причому білки, вуглеводи і солі підвищують іï, а жир, навпаки, знижує. Густину молока визначали за допомогою лактоденсиметра (ареометра). Всі досліджувані зразки питного пастеризованого коров'ячого молока відповідають вимогам стандарту щодо показника густини. Найвищу густину мав зразок №2 (1030,0 кг/ $\left.\mathrm{m}^{3}\right)$

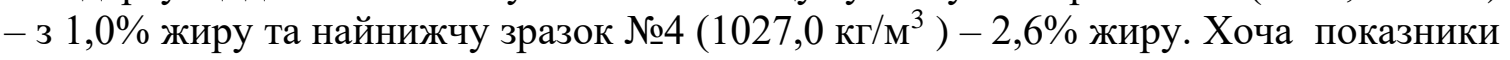
зразка №4 знаходяться на межі мінімально допустимої межі, проте жирність (жирність - один з головних параметрів який впливає на густину молока) даного зразку є найвищою серед аналізованих (2,6\%).Тому відхилення цього показника від норми може бути обумовлено розведенням водою.

Визначення кислотності молока проводили титриметричним методом. Титровану кислотність молока виражали у градусах Тернера ( $\left.{ }^{\circ} \mathrm{T}\right)$. Всі зразки питного пастеризованого коров'ячого молока українських виробників мають кислотність, яка знаходиться в межах встановленим стандартом (16-18 $\mathrm{T})$.

Дослідивши вміст жиру у відібраних зразках молока, було встановлено, що, в основному, він відповідає зазначеній на упаковці інформації щодо вмісту жиру. 
Для контролю за режимом пастеризації, а також з метою виявлення додавання сирого молока до пастеризованого використовували проби на вміст ферментів пероксидази, фосфатази і лактоальбумінову пробу. За результатами досліджень пробу на контроль пастеризації молока за мінімальної температури $75^{\circ} \mathrm{C},-$ саме за цієї температури руйнується фермент пероксидаза, не пройшов зразок питного пастеризованого коров’ячого молока №1. Причиною цьому може бути недостатньо тривала пастеризація за мінімальної температури або змішування сирого та пастеризованого молока чи фальсифікація даних на етикетці і молоко даного зразку не є пастеризованим.

Домішки додають в молоко з метою його фальсифікації. Найчастіше додають натрій гідроген карбонат (сода харчова) і крохмаль. Соду харчову додають до молока для того, щоб затримати його скисання. Хоча сода змінює кислотність молока, проте вона не затримує розвиток гнильних бактерій і в молоці з додаванням соди швидше руйнується вітамін С. Для визначення цього виду фальсифікації до молока додавали спиртовий розчин індикатора бромтимолблау (бромтимоловий синій), який в кислому та основному середовищі має різне забарвлення. При вмісті соди в молоці до 0,1\% з'являється зелений колір, 0,2 і більше - синьо-зелений; у натуральному молоці жовтий або салатовий колір. При визначенні домішок соди харчової в молоці, домішки були виявлені в зразках №1 та №4, всі інші зразки відповідають нормі. Зразок №1 має темно-салатний колій, ближче до зеленого, що вказує на наявність соди харчової до 0,1\%. Зразок №4 має зелене забарвлення, що вказує на наявність домішок соди харчової в межах 0,1 - 0,2\%.

Крохмаль чи борошно додають до молока 3 метою створення видимості густоти після розведення молока водою та виявляється реакцією з йодом. При визначенні крохмалю з розчином Люголя реакція негативна у всіх зразках.

У результаті проведених досліджень було встановлено, що, незважаючи на високу вартість, у роздрібну торгівлю потрапляє молоко із ознаками фальсифікації та порушенням певних критеріїв якості для даної групи продукції. Це продукція виробничих підприємств, які здійснюють свою виробничу діяльність згідно 3 вимогами державного стандарту, а іiї якість повинна контролюватись сертифікованими лабораторіями та органами держнагляду.

\section{Список використаних джерел}

1. Молоко коров’яче незбиране. Вимоги при закупівлі: ДСТУ 3662-97. - [Чинний від 1998 - 01 - 01 ]. - К. : Держстандарт України, 1997. - 9 с. - (Національний стандарт України).

2. Молоко. Отримання молока належної якості. Загальні вимоги: СТП001:2011. [Чинний від 2011 06 - 30]. - К. : НУБіП України, 2011. - 9 с. - (Стандарт підприємства України).

3. Молоко коров'яче питне. Загальні технічні умови: ДСТУ 2661-94. - [Чинний від 1994 - 01 - 01]. К. : Держстандарт України, 1994. - 12 с.

4. Сень О. В. Якість молока в контексті Європейських стандартів [Електронний ресурс] / О. В. Сень. - Режим доступу : http://www.rusnauka.com /23_NTP_2012/ Economics/12_114691.doc.htm. 


\section{СЕКЦІЯ 5.}

\section{БІОЛОГІЧНІ НАУКИ}

Сороколат Ірина Сергіївна, здобувач вищої освіти біологічного факультету

Одеський національний університет імені I. I. Мечникова, Україна

Науковий керівник: Іваниця Тетяна Володимирівна, канд. біол. наук, доцент, доцент кафедри мікробіології, вірусології та біотехнології

Одеський національний університет імені I. I. Мечникова, Україна

\section{БАКТЕРІЇ ЕНДОФІТНОГО СЕРЕДОВИЩА ПУХЛИН ВИНОГРАДУ ОДЕСЬКОЇ ОБЛАСТІ ТА ЇХ БІОЛОГІЧНІ ВЛАСТИВОСТІ}

Ендофітна мікробіота винограду дуже різноманітна і залежить від багатьох факторів, а саме пори року, погодних умов, наявності інфекційних захворювань, кількості мікроорганізмів у грунті, віддаленості грон від поверхні грунту, сорта винограду та інше [4].

Виноградна ендофітна мікробіота включає в себе бактерії, що населяють внутрішні тканини рослини - найчастіше судини ксилеми, де бактерії можуть вільно рухатися і міцно прикріпитися. Бактеріальні ендофіти можуть стимулювати ріст рослин, пригнічувати розвиток патогенних мікроорганізмів і посилювати імунну відповідь рослин, проте також можуть викликати захворювання рослин [1-2]. Вивчення комплексів мікроорганізмів в фітосфері сільськогосподарських рослин необхідно як для виявлення факторів їх спрямованої регуляції, так і для розробки стратегії пошуку i виділення комплементарних 3 рослинами асоціативних мікроорганізмів з фіторегуляторними і біоконтрольними властивостями [3].

Мета дослідження - виділити штами мікроорганізмів із ендофітного середовища пухлин винограду Одеської області та дослідити їх біологічні властивості.

Виділяли бактерії із ендофітного середовища пухлин винограду сортів «Аркадія» та «Молдова» за методикою виділення бактерій з тканин рослин. Для встановлення родової належності досліджували культуральні, морфологічні та деякі біохімічні властивості бактерій, виділених 3 ендофітного середовища пухлин винограду.

Бактерії роду Pantoea можуть пригнічувати ріст патогенних бактерій, посилювати імунну відповідь рослин, однак також можуть викликати i захворювання рослин [5]. Виділені бактерії роду Pantoea утворюють на поживному агарі жовті, округлі, гладкі, блискучі колонії. Ці бактерії грамнегативні палички із закругленими кінцями. Розміри клітин визначаються в межах 0,5 - 1,0×1 - 3 мкм. Всі виділені бактерії утилізували вуглеводи маніт та глюкозу з утворенням кислоти в анаеробних та аеробних умовах. Всі мікроорганізми мали здатність до продукування каталази, та не продукували оксидазу. Реакція Фогеса-Проскауера позитивна для всіх штамів, тобто відбулось бутанолове бродіння глюкози 3 утворенням діацетилу.

Виділені бактерії роду Dickeya зазвичай викликають захворювання різноманітних сільськогосподарських рослин [6]. Вони утворюють на поживному агарі невеликі круглі 3 рівними краями блискучі колонії жовтого кольору 3 
маслянистою консистенцією. Виділені бактерії грамнегативні, паличковидні, а розміри клітин визначаються в межах 0,7-0,1 х 0,9-1,5 мкм. Всі штами утилізували вуглеводи маніт та глюкозу з утворенням кислоти в анаеробних та аеробних умовах, арабінозу тільки в аеробних умовах. Всі виділенні штами бактерій $\epsilon$ каталазопозитивними та оксидазонегативними. Реакція Фогеса-Проскауера позитивна для всіх штамів.

Роль бактерій роду Cedecea в рослині до кінця ще не з'ясовано [7]. Виділені бактерії формували на поживному агарі бежеві або жовтуваті, округлі та гладкі колонії. Виділені бактерії грамнегативні палички, з розміром клітин $0,6-0,7 \times 1,3-$ 1,9 мкм. Всі мікроорганізми утилізували маніт та глюкозу в аеробних та анаеробних умовах, частково сахарозу та арабінозу. Тест на продукування каталази позитивний, на продукування оксидази негативний. Реакція Фогеса-Проскауера позитивна для всіх штамів.

Бактерії роду Rhizobium майже завжди викликають захворювання рослин, такі як бактеріальний рак і неконтрольоване розростання кореневої системи [8]. Виділені бактерії на агаризованих поживних середовищах утворюють опуклі, круглі гладкі непігментовані або слабо-бежеві колонії. Виділені бактерії грамнегативні, прямі або злегка зігнуті палички, з розміром клітин 0,6 - 1,0 × 1,5- 3,0 мкм. Всі бактерії утилізували глюкозу та маніт в аеробних та в анаеробних умовах, причому при утилізації останнього у деяких бактерій спостерігалось виділення газу в обох умовах. Утилізували сахарозу та арабінозу частково, причому з газовиділенням в обох умовах. Тест на каталазу у всіх штамів позитивний, на оксидазу позитивний. Реакція Фогеса-Проскауера позитивна для всіх штамів.

Для визначення видового складу було проведено жирно-кислотний аналіз клітин виділених мікроорганізмів:

- для бактерій роду Pantoea домінуючими є гексадеканова (C16:0) та тетрадеканова (C14:0) кислоти, що характерними є для виду Pantoea agglomerans;

- для бактерій роду Dickeya домінуючими є гексадеканова (C16:0), октадеканова (C18:0) та гептадеканова (C17:0) кислоти, що характерними є для виду Dickeya dadantii;

- для бактерій роду Cеdecea домінуючими є тетрадеканова (C14:0), додеканова (C12:0) та гексадеканова (C16:0) кислоти, що характерними є для виду Cedecea davisae;

- для бактерій роду Rhizobium домінуючими $є$ тридеканова (C13:0), пентадеканова (C15:0), гексадеканова (C16:0) та ейкозанова (C20:0) кислоти, що характерними є для виду Rhizobium radiobacter.

Висновки. Таким чином, виділили із ендофітного середовища пухлин винограду (Vitis vinifera) та ідентифікували бактерії таких видів: Pantoea agglomerans, Dickeya dadantii, Rhizobium radiobacter, та Cedecea davisae. Це $\epsilon$ важливим кроком для розробки методів захисту рослин від бактеріального раку, оскільки можна створювати колекції штамів, виділених з винограду Одеської області. На таких штамах в подальшому можна буде перевіряти вплив нових різноманітних біологічних або хімічних препаратів.

\section{Список використаних джерел:}

1. Иванченко В.И. (2009) Состояние виноградарства и повышение его эффективности для производства конурентной винодельческой продукции. Виноградарство и виноделие , № 3, 79. Вилучено з:

2. http://www.nbuv.gov.ua/Portal/Chem_Biol/Magarach/2009_3/mv_7-9.pdf.

3. Маринова І.І. Іваниця В.Ю. \& Ліманська Н.В. (2016). Чисельність ендофітної мікробіоти пагонів винограду. Мікробіологія і біотехнологія. Одеса: №1, 40-46. 
4. Чеботарь В. К., Щербаков А.В. \& Щербакова Е.Н. (2015). (Т. 50) Эндофитные бактерии как перспективный биотехнологический ресурс и их разнообразие. Сельскохозяйственная биология, № 5, 648-654.

5. Штеренберг П.М. (1979). О распространении возбудителя бактериального рака в лозе бессимптомных кустов винограда. Садоводство, виноградарство и виноделие Молдавии, № 8, 41-43.

6. Johnson K. B., Stockwell K. B. \& Sugar D. (2000). (V. 90). Assessment of Environmental Factors Influencing Growth and Spread of Pantoea agglomerans on and Among Blossoms of Pear and Apple. Phytopathology, №11, 1285-1294.

7. Czajkowski R., W. J. de Boer, van Veen J. A., \& van der Wolf W. J. (2012). (V. 61). Characterization of bacterial isolates from rotting potato tuber tissue showing antagonism to Dickeya sp. biovar 3 in vitro and in planta. Plant Pathology, 169-182.

8. Grimont P., Grimont F., Farmer III J., \& Asbury M. (1981). (V. 31). Cedecea davisae gen. nov., sp. nov. and Cedecea lapagei sp. nov., New Enterobacteriaceae from Clinical Specimens . Int J Syst Bacteriol., №3, 317-326.

9. Lai CC., Teng LJ, Hsueh PR. (2004). (V. 38.). Clinical and microbial characteristics of Rhizobium radiobacter infections. Clin Infect Dis., 149-43.

Додон Дар'я Сергіївна, здобувач вищої освіти біолого-екологічного факультету Дніпровський начіональний університет імені Олеся Гончара, Украӥна

\section{Наукові керівники:}

Дрегваль Оксана Анатольївна, канд. біолог. наук, доцент, доцент кафедри мікробіології, вірусології та біотехнології Дніпровський начіональний університет імені Олеся Гончара, Украӥна

Соколова Ірина Свгенівна, канд. біолог. наук, доцент, доцент кафедри мікробіології, вірусології та біотехнології Дніпровський національний університет імені Олеся Гончара, Україна

Скляр Тетяна Володимирівна, канд. біолог. наук, доцент, завідувач кафедри мікробіології, вірусології та біотехнології

Дніпровський національний університет імені Олеся Гончара, Украйна

\section{ІДЕНТИФІКАЦІЯ ІЗОЛЯТУ ФІТОПАТОГЕННИХ БАКТЕРІЙ, ВИДІЛЕНОГО $З$ УРАЖЕНОГО ЛИСТЯ ГІРКОКАШТАНУ ЗВИЧАЙНОГО (AESCULUS HIPPOCASTANUM L.)}

Масове ураження гіркокаштану звичайного (Aesculus hippocastanum L.), що призводить до завчасного пожовтіння та усихання його листя, на території України спостерігається 31998 р.. Причина даного явища - Cameraria ohridella, або мінуюча міль [1], яка може бути переносником фітопатогенів або істотно знижувати імунітет рослини, що призводить до активації паразитичних властивостей бактерійсимбіонтів Aesculus hippocastanum. Ушкоджені крони гіркокаштану не здатні накопичувати достатню кількість органічних речовин, що може призвести до вимерзання та всихання дерев взимку [2,3]. Саме тому актуальні завчасне виявлення та ідентифікація супутніх паразиту фітопатогенних мікроорганізмів, а також розробка методів боротьби з ними.

Мета роботи - виділення фітопатогенних бактерій з ураженого листя Aesculus hippocastanum, їх ідентифікація за морфологічними, культуральними та фізіолого- 
біохімічними властивостями, а також вивчення чутливості виділених бактерій до антибіотичних сполук.

Для виділення фітопатогенних бактерій використані зразки листя гіркокаштану звичайного на яких спостерігалися "опіки" від дії патогену. Виділення бактерій проводили висівом на м'ясо-пептонний агар.

Для ідентифікації культури фітопатогена вивчалися його властивості: морфологічні (будова бактеріальної стінки, форма клітин), культуральні, фізіологічні та біохімічні.

В результаті проведених досліджень виділено ізолят рухливих грамнегативних паличкоподібних бактерій розміром $0,6 \times 2$ мкм, що утворюють на щільних поживних середовищах круглі жовті колонії з піднесеним центром, спочатку білі, пізніше жовтого кольору. Виділені бактерії здатні розщеплювати ряд вуглеводів та спиртів з утворенням кислоти: глюкозу, фруктозу, галактозу, арабінозу, сахарозу, сорбіт, маніт, лактозу, L-рамнозу, манозу, крохмаль та гліцерин; виділяють індол, не утворюють сірководню $з$ цистеїну, накопичують ацетоїн, утилізують цитрат, малонат та фенілаланін, ростуть в діапазоні температур від 4 до $37^{\circ} \mathrm{C}$ та в присутності 5\% NaCl, продукують ферменти - желатиназу, каталазу й нітратредуктазу; оксидазонегативні.

На основі визначника Берджі [4] виділений ізолят віднесено до Pantoea ananatis (раніше Erwinia uredovora). В залежності від умов навколишнього середовища та хазяїна ці бактерії можуть проявляти властивості епіфіта, ендофіта, сапрофіта або фітопатогена [5].

Чутливість виділених бактерій до антимікробних препаратів визначали методом паперових дисків, просичених такими антибіотиками, як азитроміцин, тетрациклін, левоміцетин, еритроміцин та цефтріаксон. Найбільші зони відсутності росту $P$. ananatis встановлено для левоміцетину (25 $\pm 1,3$ мм), синтетичного аналогу хлорамфенікола, природним продуцентом якого є Streptomyces venezuelae.

Висновки. 3 ураженого листя Aesculus hippocastanum виділено бактерію, ідентифіковану як Pantoea ananatis, чутливу до левоміцитину. В подальших дослідженнях планується детальне вивчення біологічних властивостей даного штаму та пошук його природних антагоністів серед стрептоміцетів.

\section{Список використаних джерел:}

1. Мониторинг каштановой минирующей моли / С. А. Трібель, О. Н. Гаманова // Защита и карантин растений. - 2009. - №2. - С. 45-47.;

2. Черпаков В.В. / О бактериальном поражении Pseudomonas syringae pv. Aesculi конского каштана в Российской Федерации // Актуальные проблемы лесного комплекса. — 2013. — №37. C. 70-77.;

3. Вплив біотичних факторів на стан парково-вуличних насаджень дерев каштана / Е. М. Попова, А. В. Дражнікова, Т. В. Луценко // Наукові доповіді НУБіП. - 2011. — № 7 (23). - С. 1-10.;

4. Bergey's Manual of Systematic Bacteriology. Vol. 2. The Proteobacteria. Part B. The Gammaproteobacteria / Brenner D.J., Krieg N.R. et al. (eds.) // Springer. - 2004. - 1136 p.;

5. Pantoea ananatis: an unconventional plant pathogen / Coutinho, Teresa A, and Stephanus N Venter // Molecular plant pathology. — 2011. — №10 (3). — C. 325-335. doi:10.1111/j.1364-

3703.2009.00542.x. 
Мудренко Мария Александровна, студентка биолого-экологического факультета Днепровский национальньй университет им. Олеся Гончара, Украина

\section{ФИНАНСИРОВАНИЕ БИОТЕХНОЛОГИЧЕСКИХ ЛАБОРАТОРИЙ КАК СПОСОБ ПОВЫШЕНИЯ ИХ ЭНЕРГОЭФФЕКТИВНОСТИ}

На сегодняшний день, учитывая угрозу экологического кризиса, большое значение придают вопросам экономии природных ресурсов как в быту, так и на производстве. С этой целью используют обновлённое оборудование, которое помогает в несколько раз сократить потребление ресурсов. При этом, несмотря на развитие технологий, в некоторых лабораториях до сих пор применяются методики, которые являются неоправданными с точки зрения энергоэффективности. Их использование обусловлено многими факторами, одним из которых является недостаточное финансирование или полное его отсутствие. Как следствие, у таких лабораторий нет возможности закупить необходимые материалы и оборудование, поэтому отдается предпочтение устаревшим технологиям. В данной работе рассмотрены недостатки использования подобных методов и доказана необходимость полноценного финансирования биотехнологических лабораторий.

Одним из вышеупомянутых методов является получение агара и агарозы. Эти реактивы используются при образовании гелей, применяемых в научных исследованиях для электрофореза, приготовления культуральных жидкостей и др. У исследователя есть два варианта получения этих реактивов: приобрести готовые у производителя или изготовить самостоятельно. Первый является более оптимальным из-за экономии времени и трудовых ресурсов и в то же время слишком дорогим при ограниченных денежных средствах, так как стоимость 500 граммов агарозы в среднем составляет 350 евро. Именно поэтому исследователь, не получающий должную финансовую поддержку, вынужден собственноручно изготавливать реактив.

Согласно методике сырье (красную водоросль Ahnfeltia Tobuchiensis) необходимо замочить в известковом растворе, экстрагировать и далее промывать проточной водой в течении 30-36 часов [1]. Далее гель выпаривают и высушивают или дополнительно экстрагируют, в зависимости от требуемой степени очистки продукта. Согласно методике, выход продукта из 50 кг сырья составляет 3,55 кг агарового геля (7,1\% массы исходного сырья) после первого экстрагирования и 2,75 кг (5,5\% массы исходного сырья) после третьего.

В случае, если исследователь имеет целью получение агарозы, проводится ряд манипуляций, после чего из полученных 2,75 кг агарового геля выход продукта составляет 0,530 кг агарозы $(1,1 \%$ от первоначальной массы). Такой собственноручно изготовленный реактив значительно экономит денежные средства лаборатории. Однако в данной ситуации следует учесть расход природных ресурсов, а именно - воды. Если предположить, что диаметр лабораторного крана является стандартной величиной - 25 мм и расход воды из него составляет 1,2 л/с, то при получении целевого вещества расходуется 129600-155520 л воды, не считая потери водяного потока [2]. Такое количество воды сливается в канализацию по той причине, что в лабораторных условиях, в отличие от предприятия, её нельзя использовать повторно в качестве оборотной воды для других технологических процессов, таких как охлаждение, нагрев глухим паром и др. 
Во времена экологического кризиса расход такого количества ресурсов является неоправданным. Вышеупомянутые реактивы являются необходимой составляющей биотехнологических исследований, поэтому отказаться от их использования невозможно. В результате сравнения затрат на материалы понятно, что более экологичной является их закупка. Кроме того, приобретение реактивов в готовом виде позволит существенно сэкономить время подготовки к проведению исследования.

Таким образом, финансирование биотехнологических лабораторий является необходимым условием для проведения успешных исследований и условием разумного природопользования. Необходимо выделять достаточно средств на материальное и техническое обеспечение лаборатории, чтобы избежать неоправданных трат природных ресурсов, которые могут стать причиной экологических проблем.

\section{Список использованных источников:}

1. Розенберг А. Л., Фазлутдинов И. В., "Методы выделения и культивирования водорослей" - Уфа, 1989 , с. $143-149$

2. Способы расчета пропускной способности трубопровода, - Электронный ресурс https://www.sciencedebate2008.com/rasschet-propusknoi-sposobnosti-truboprovoda/ 


\section{СЕКЦІЯ 6.}

\section{МЕДИЧНІ НАУКИ}

Ivan Nahornyi, applicant for Higher Education II Medical Faculty Kharkiv National Medical University, Ukraine

\section{Scientific advisers:}

Liliya Bobro, Ph. D. (Medicine), Associate Professor of the Department of General Practice - Family Medicine and Internal Diseases Kharkiv National Medical University, Ukraine

Alina Andrusha, Ph. D. (Medicine), Associate Professor of the Department of General Practice - Family Medicine Family Medicine and Internal Diseases Kharkiv National Medical University, Ukraime

\section{FEATURES OF ARTERIAL HYPERTENSION IN PATIENTS WITH HYPOTHYROIDISM}

Introduction. In recent years, there has been a tendency to increase the incidence of hypothyroidism. In European countries and USA, the prevalence of primary hypothyroidism in the population is $0.2-2 \%$ [1]. The diagnosis and treatment of arterial hypertension $(\mathrm{AH})$ in patients with hypothyroidism is very important issue, given the widespread prevalence of hypertension in patients with reduced thyroid function. Thus, according to various authors, hypertension with hypothyroidism is observed in $10-50 \%$ of patients $[1,2]$.

Purpose of study. To study characteristics of hypertension in patients with primary hypothyroidism receiving hormone replacement therapy (HRT) with L-thyroxine.

Materials and methods. 32 patients with primary hypothyroidism in the phase of subcompensation were examined: $26(81 \%)$ women and $6(19 \%)$ men. The average age of the patients was $58.3 \pm 5.7$ years, the duration of HRT was $8.53 \pm 3.34$ years. All surveyed underwent conducted daily monitoring of blood pressure every hour. The average systolic pressure per day (SAP pd.), The average diastolic pressure per day (DAP pd.) were determined. The consumption of antihypertensive drugs in patients was excluded (allowed only with a sharp increase in blood pressure).

Results. According to the results of AH monitoring first degree was established in 14 (44\%) patients. In this group, SAP pd. was $142 \pm 4.05 \mathrm{~mm}$. Hg, DAP pd. $92 \pm 3.6 \mathrm{~mm}$. $\mathrm{Hg}$ Art. The duration of HRT was $11.4 \pm 3.8$ years. Second degree of AH was diagnosed in $18(56 \%)$ patients: SAP pd. was $162.5 \pm 2.3 \mathrm{mmHg}$, DAP pd. $97.53 \pm 3.41 \mathrm{mmHg}$. The average duration of HRT in this group was $7.2 \pm 4.6$ years.

Conclusion. All examined patients with subcompensated hypothyroidism 1-2 degrees of hypertension were diagnosed. There is a tendency for an increase number of patients with second degree of arterial hypertension. The inverse relationship between the duration of hormone replacement therapy and the degree of hypertension was found.

\section{References:}

1. Скаржинская Н.С., Чесникова А.И., Сафроненко В.А. (2016) Особенности артериальной гипертензии у больных гипотиреозом, пути медикаментозной коррекции. Артериальная гипертензия, (22,4), 401-413. https://doi.org/10.18705/1607-419X-2016-22-4-401-413 
2. Волкова А.Р., Беркович О.А., Дора С.В., Дыгун О.Д. (2015) Субклинический гипотиреоз и риск артериальной гипертензии у больных ишемической болезнью сердца. Артериальная гипертензия,(21,4),409-415. https://doi.org/10.18705/1607-419X-2015-21-4-409-415 21-4-409-415

Стоян Анна Олегівна, здобувач вищої освіти медичного факультету, Харківський національний медичний університет, Украйна

Науковий керівник: Орел Ольга Володимирівна, асистент кафедри громадського здоров'я та управління охороною здоров'я

Харківський національний медичний університет, Украӥна

\section{ВИВЧЕННЯ ПРОБЛЕМ РЕПРОДУКТИВНОГО ЗДОРОВ'Я СУЧАСНӦ̈ МОЛОДІ}

Актуальність. На Україні внаслідок глибокої демографічної кризи проблема репродуктивного здоров'я набула особливої актуальності. Поняття «репродуктивне здоров'я» передбачає можливість зачати, виносити і народити здорову дитину. У період політичної, соціальної та економічної дестабілізації суспільства, крім зростання в молодіжному середовищі криміногенності і асоціальності, становище ускладнюється підвищенням сексуальної активності, обумовленої в більшій мірі соціальними мотивами. Вирішення цієї проблеми багато в чому залежить від сексуальної культури, усвідомленого планування сім'ї та профілактики абортів у неповнолітніх.

Мета. Вивчити проблеми репродуктивного здоров’я сучасної молоді 3 використанням статистичних даних.

Виклад матеріалу. Сучасний підхід до охорони здоров'я все більше грунтується на тому, що підлітки і молодь є окремою віковою групою, що не відносяться до дітей або дорослих. Специфічні потреби і інтереси підлітків у випадку охорони здоров'я обумовлені їх швидким фізичним розвитком, а також соціальними, статевими та особистісними змінами, які супроводжують процес дорослішання. Необізнаність в сексуальних питаннях сприяє виникненню таких явищ, як випадкова вагітність, захворювання, що передаються статевим шляхом, згвалтування і сексуальна експлуатація, сексуальні проблеми, які призводять до порушення сексуального та репродуктивного здоров'я. У країнах з перехідною економікою процес дорослішання підліткової групи населення відбувається в умовах високого ризику для здоров'я. Бідність, нерівність, ослаблення соціальних зв'язків, етнічні та сімейні тертя, конфлікти, дискримінація, що відбуваються на тлі швидких змін в суспільстві - це проблеми, з якими в тій чи іншій мірі стикаються всі країни і які безпосередньо загрожують здоров'ю та розвитку підростаючого покоління. Прямим їх наслідком є погане харчування, зловживання алкоголем, тютюнопаління, інфекційні захворювання, депресії і підвищений рівень тривожності, самогубства, ранній початок статевого життя при недотриманні правил безпечного сексу, і рання вагітність [2].

Вагітність в підлітковому віці збільшує захворюваність і смертність самих підлітків і їхніх дітей; більшість позашлюбних вагітностей зазвичай закінчується абортом. Аборт, вироблений під час першої вагітності, за визнанням медиків, збільшує ризик гінекологічних захворювань і виникнення безпліддя. Статистичні дані в Україні свідчать про те, що у віці 15-16 років щорічно вагітність перериває понад 1200 дівчат. Показник числа абортів у дівчат-підлітків 16-19 років за останні 
роки, залишається високим, більш ніж в 2-3 рази перевищуючи аналогічні показники таких країн, як Фінляндія, Швеція, Данія, Нідерланди [1].

Аналіз досліджень за 2019 рік показує, що сексуальна поведінка молоді в Україні зазнала істотних змін і характеризується більш розкутим ставленням. Про це свідчить поширення дошлюбних сексуальних контактів, зниження віку початку сексуального життя, часта зміна партнерів, щорічне зростання позашлюбної народжуваності.Стан сексуального та репродуктивного здоров'я молоді залежить від ряду важливих причин, на які може вплинути комплексна і систематична робота всіх фахівців з профілактики порушень сексуальної поведінки і репродуктивного здоров'я у підлітків та молоді. На сьогодні 63\% підлітків 12-14 років регулярно обговорюють 3 батьками проблеми свого здоров'я, 61\% говорять про друзів, 67\% про майбутнє, $41 \%$ - про стосунки в родині. Більш закритими темами залишаються питання статевої зрілості і інтимних стосунків між чоловіком і жінкою (12 і 5\%, відповідно, говорять про це з батьками) і навіть взаємовідносин між хлопчиками і дівчатками (25\%). Статева активність підлітків дуже висока. Більш 53,5\% почали статеве життя у віці 13-16 років. Серед підлітків, які живуть статевим життям і уникають вагітності: 64,3\% дівчат і 82,5\% юнаків у віці $14-17$ років і 76,9\% дівчат і $74,2 \%$ юнаків у віці 18-20 років, вони відзначили, що використовують методи контрацепції. У той же час, близько $25,7 \%$ опитаних юнаків і дівчат у вікових групах 14 - 20 років підтвердили, що не користуються методами захисту, від небажаної вагітності; у віці 16-19 років 84,7\% всіх вагітностей, що настали, закінчилися абортом. Залишається високою захворюваність хворобами, які передаються статевим шляхом. Наявність захворюваності в минулому або зараз підтвердили $25,8 \%$ юнаків і $37,5 \%$ дівчат [1].

Катастрофічне зростання ІПСШ та ВІЛ-інфекції у підлітків і молоді в поєднанні зі способом життя, чинним згубно на їх здоров'я (вживання алкоголю, куріння, прилучення до наркотиків) - являє серйозну загрозу їх сексуальному і репродуктивному здоров'ю. Ці захворювання в поєднанні з величезним числом абортів і згубним для здоров'я способом життя руйнують репродуктивне здоров'я майбутніх матерів, і малоймовірно, що ці дівчата зможуть народити здорове потомство [2].

Висновок. Основна мета сексуальної освіти полягає в тому, щоб навчити молодих людей приймати поінформовані відповідальні рішення, що стосуються власної сексуальної поведінки i репродуктивного здоров'я. Постає висока необхідність створення дієвої системи моніторингу за станом репродуктивного та сексуального здоров'я підлітків, розробки ефективного механізму реалізації медикопсихологічних послуг.

\section{Список використаних джерел:}

1. Дідкова-Фаворська Д.М. (2018) Репродуктивні практики в контексті молодіжної повсякденності. Харків. Автореферат на здобуття наук.ступеня канд. соціол. наук.

3. Цушко I.I. (2013). Формування навичок захисту і збереження репродуктивного здоров'я учнівської і студентської молоді. Київ, Український НМЦ практичної психології і соціальної роботи. 
Гуманець Карина Романівна ${ }^{\circledR}$, здобувач вищої освіти IV медичного факультету Харківський національний медичний університет, Украӥна

Марченко Ірина Олександрівна ${ }^{\bullet}$, здобувач вищої освіти II медичного факультету Харківський національний медичний університет, Украйна

Науковий керівник: Древаль Мар'яна Василівна, асистент кафедри гігієни та екології №1

Харківський національний медичний університет, Украӥна

\section{ВПЛИВ ЗОВНІШНІХ ФАКТОРІВ НА РОЗВИТОК ЗАГОСТРЕНЬ БРОНХІАЛЬНОЇ АСТМИ}

Актуальність. Серед усіх алергічних захворювань найбільш поширеною залишається бронхіальна астма (БА). У світі вже нараховується близько 300 млн хворих на цю недугу, i, за прогнозом, до 2025 р. їх кількість збільшиться ще на 100 млн. Астма належить до тих захворювань, які найбільше впливають на показники смертності населення або суттєво знижують якість життя пацієнта і лікуються на амбулаторному рівні. За даними офіційної статистики, в Україні на 100 тис. дорослого населення припадає майже 500 хворих на БА. На думку фахівців, це не відповідає реальній ситуації через існуючі недоліки в діагностиці даної патології, а насправді кількість хворих значно вища.

Розкриття теми. Бронхіальна астма є гетерогенним захворюванням, яке, як правило, характеризується наявністю хронічного запалення дихальних шляхів. Хвороба визначається за наявністю в анамнезі симптомів з боку органів дихання, таких як свистячі хрипи, задишка, відчуття закладеності в грудях і кашель, вираженість яких змінюється з часом, а також варіабельного обмеження швидкості повітряного потоку на видиху [1].

Розрізняють дві групи факторів, що сприяють виникненню бронхіальної астми. Одну групу називають внутрішніми факторами, які включають спадкові генетичні чинники, стать, ожиріння. До другої групи відносять зовнішні фактори. До найбільш поширених з них, які провокують розвиток захворювання і сприяють загостренню бронхіальної астми, відносяться: побутові алергени (домашній пил, кліщі домашнього пилу), алергени тварин, покритих шерстю, алергени тарганів, грибкові алергени, пилкові алергени, хімічні речовини, забруднення повітря всередині і зовні приміщень, куріння, застуди, прийом ацетилсаліцилової кислоти.

Домашній пил є багатокомпонентним алергеном. Основним алергизиючим фактором домашнього пилу, 3 яким людина стикається щодня, $\epsilon$ кліщі Dermatophagoides pteronyssinus i Dermatophagoides farinae. Житло людини має всі умови, в яких можуть проживати мікрокліщі (відносна вологість 75\% - 85\% і температура 23 - $27^{\circ} \mathrm{C}$ ). Основна концентрація кліщів знаходиться в ліжку людини. Харчовим субстратом для них служать лусочки верхнього шару шкіри, цвіль і залишки їжі. За даними ряду авторів сенсибілізація до кліщів Dermatophagoides pteronyssinus i Dermatophagoides farinae, в різних регіонах, становить від $71 \%$ до $91 \%$ [2].

Часто в розвитку бронхіальної астми відіграють роль домашні тварини - кішки, собаки, гризуни. Алергени містяться у відмираючих клітинах шкірних покривів тварини, лупі, слині, сечі, секретах різних залоз цих тварин. 
Окрім цього, була досліджена роль тарганів в провокуванні нападів бронхіальної астми. Основні алергени цих комах містяться в їх виділеннях. $€$ дані, що до алергенів тарганів чутливі не менше $30 \%$ астматиків.

Напади задухи можуть виникати при підвищеній чутливості до рослинних алергенів, що містяться в пилку вітрозапилюваних рослин, а також до спор грибів, концентрація яких в повітрі навіть в період інтенсивного цвітіння рослин в 1000 разів перевищує концентрацію зерен пилку. Особливу небезпеку становлять саме цвілеві гриби. Дуже часто (до 70\% випадків) зустрічається поєднання алергії до цвілевих грибів і кліща домашнього пилу.

Крім впливу неінфекційних алергенів велике провокуюче значення у розвитку нападів задухи мають гострі респіраторні вірусні інфекції. Як відомо, вірусні інфекції різко підвищують чутливість бронхів до алергенів і інших подразників, збільшують проникність бар'єрів, порушують роботу мукоциліарного апарату бронхів [3].

Також варто відмітити професійні «шкідливості», які можуть бути як алергічного, так і неалергічного походження. В даний час налічується більше 100 речовин, які можуть викликати професійну бронхіальну астму. 3 них найчастіше цьому сприяють: латекс (робота на фармацевтичних підприємствах, в лікувальних установах), ізоціанати (виробництво поліуретану, пластмас), ангідриди (робота на підприємствах хімічної та текстильної промисловості), деревний пил (деревообробна промисловість).

Велику роль в розвитку захворювання відіграє тютюнопаління, як активне, так і пасивне, сприяючи захворюваності БА. Воно збільшує іiі тяжкість і ризик розвитку загострень, перешкоджає досягненню контролю і порушує адекватну відповідь на фармакотерапію. Куріння у хворих на бронхіальну астму пов'язано з індукцією запалення в дихальних шляхах, 3 розвитком незворотних морфологічних змін дихальних шляхів, з формуванням "повітряних пасток", з гетерогенністю вентиляції легенів і порушенням функції легенів [4]. Варто зауважити, що тютюнопаління у підлітковому віці збільшує ризики стійкої астми [5].

Крім перерахованого вище, всередині приміщення також існує безліч факторів, що сприяють розвитку бронхіальної астми. До них відносяться: речовини, які є продуктами життєдіяльності людини (аміак, оксиди азоту та вуглецю, сірководень), хімічні речовини (окис та двоокис вуглецю, двоокис сірки) та інгалююмі тверді частинки, що виділяються при використанні в побуті для приготування їжі і (або) в опалювальних цілях (газові плити, печі), хімічні речовини, що виділяються будівельними та оздоблювальними матеріалами, поліуретанові фарби, різні аерозолі. Поза приміщеннями основними джерелами забруднення атмосферного повітря $є$ автомобілі, промислові підприємства (хімічні та металургійні), теплоелектростанції.

Розвитку бронхіальної астми і алергічних реакцій може сприяти також будьякий харчовий продукт і харчові добавки (барвники, ароматизатори та консерванти). Найбільш часто харчову алергію викликають яйця, коров'яче молоко, пшениця, кукурудза, арахіс, лісові горіхи, молюски, ракоподібні. 3 харчових добавок найбільш небезпечні: глутамат натрію, нітрити, нітрати, бензоат натрію, сульфіти, а також жовтий барвник тартразин, який присутній в продуктах і препаратах, що мають помаранчевий або жовтий колір.

Висновок. Розвиток загострень БА пов'язаний з широким спектром зовнішніх факторів ризику. Оскільки однією з довгострокових цілей терапії БА є профілактика загострень захворювання, потенційні фактори ризику потребують ретельного 
виявлення і за можливості корекції, що дозволить розраховувати на більш ефективне лікування хворих на бронхіальну астму [6].

\section{Список використаних джерел:}

1. Global strategy for asthma management and prevention. (2014). Global Initiative for Asthma (GINA). 2. Retrieved from https://ginasthma.org/wp-content/uploads/2019/01/2014-GINA.pdf

2. Гайнутдинова Р. И. (2005). Особенности бронхиальной астмы, обусловленной клещевой сенсибилизацией, у детей в Удмуртской Республике (автореф. дис. ... кандидата мед. наук). Ижевская государственная медицинская академия, Ижевск, Российская Федерация.

3. Макарова М. А. (2016). Бронхиальная астма весной: чего надо опасаться. Астма и аллергия, (1), 15-16.

4. Ненашева Н. М. (2013). Курение и бронхиальная астма. Астма и аллергия, (1), 28-36.

5. Бронхіальна астма. Адаптована клінічна настанова, заснована на доказах, (2013), 49. Вилучено 3 https://dec.gov.ua/wp-content/uploads/2019/11/2013_868_kn_ba.pdf

6. Черняк Б. А., Иванов А. Ф. (2017). Факторы риска обострений бронхиальной астмы. Астма $u$ аллергия, (4), 3-6.

Остапенко Дар'я Миколаївна, здобувач вищої освіти II медичного факультету Харківський національний медичний університет, Украйна

Науковий керівник: Бобро Лілія Миколаївна, канд. мед. наук, доцент кафедри загальної практики - сімейної медицини та внутрішніх хвороб

Харківський національний медичний університет, Украӥна

\section{ВПЛИВ ЦУКРОВОГО ДІАБЕТУ НА ПРОГНОЗ ЩОДО ВИЖИВАННЯ ПАЦІЕНТІВ ІЗ РАКОМ ПРЯМОЇ КИШКИ}

На сьогодні $є$ дуже актуальним дослідження захворювань, перебіг яких коморбідний із цукровим діабетом [1]. Але в літературі недостатньо освітлено вплив цукрового дыабету (ЦД) на прогноз щодо виживання пацієнтів із раком прямої кишки. Існує декілька ймовірних фізіологічних механізмів, які пов'язують ЦД та онкологічні захворювання: гіперінсулінемія (а також інсуліноподібні фактори росту та білки, що їх зв'язують), гіперглікемія та запалення $[1,2]$. Резистентність до інсуліну та виникаюча в результаті гіперінсулінемія можуть сприяти транскрипції генів та росту онкологічних клітин, а також інгібуванню апоптозу. Гіперглікемія сприяє проліферації клітин шляхом генерації активних форм кисню та наступної активації шляху, який регулюється позаклітинним сигналом міогенактивованих протеїнкіназ [2].

Мета дослідження: провести аналіз тяжкості перебігу та показників летальності у пацієнтів із раком прямої кишки на тлі цукрового діабету за останні 5 років.

Матеріали та методи. Було проведено ретроспективний аналіз (за останні 5 років) 87 амбулаторних карт пацієнтів, які страждали на рак прямої кишки III-IУ клінічних груп. Всіх досліджуваних було поділено на 2 групи: I група складалася iз 31 (35,6\%) пацієнта із ЦД 2 типу, II група - без ЦД (56 пацієнтів - 64,4\%). Вік пацієнтів в обох групах становив $65,3 \pm 3$ роки. Діагноз ЦД 2 типу був встановлений ендокринологом. ЦД або передував встановленню рака прямої кишки, або був встановлений після виявлення раку. В обох випадках різниця між термінами захворювань не перевищувала 3 роки. Всі пацієнти із ЦД отримували пероральну 
цукрознижувальну терапію. Методи лікування раку прямої кишки були однакові у всіх пацієнтів - хіміотерапія.

Результати. Достовірної різниці між показниками загальної виживаності (3В) у пацієнтів I і II групи не відзначено, але пацієнти I групи (з ЦД) мали більш низькі показники 3В, ніж пацієнти II групи: середній показник ЗВ складав 21,8 місяців серед хворих на ЦД та 26,9 місяців серед хворих без ЦД ( $>>0,05)$. Погіршення стану iз ознаками прогресування злоякісного новоутворення через 8,9 місяців спостерігалось у 30 (97\%) пацієнтів I групи і у 27 (48\%) пацієнтів II групи $\left(\chi^{2}=20,8\right.$, $\mathrm{p}<0,001)$.

Висновки. Отже, ми можемо відзначити погіршення прогнозу перебігу раку прямої кишки у пацієнтів із цукровим діабетом. Ці результати підкреслюють необхідність подальших досліджень для розуміння всіх гіпотетичних фізіологічних механізмів, які $є$ патогенетичним підгрунтям взаємообтяжуючого перебігу при коморбідності цукрового діабету і раку прямої кишки.

\section{Список використаних джерел:}

1. Garg S. K., Maurer H., Reed K., Selagamsetty R. (2014) Diabetes and cancer: two diseases with obesity as a common risk factor. Diabetes, Obesity and Metabolism. 16(2), 97-110.

2. Мисникова И.В. (23016) Сахарный диабет и рак. «РМЖ», (20),1346-1350

DOI 10.36074/17.04.2020.v2.05

Копитько Назар Станіславович, учень 11-М класу

Комунальний заклад «Полтавська гімназія №6», Украӥна

Науковий керівник: Шапошник Ольга Анатоліївна, кандидат медичних наук, доцент кафедри внутрішньої медицини №1 3 професійними хворобами УМСА, Україна

\section{ЕМОЦЙНИЙ ІНТЕЛЕКТ ЯК ПЕРЕДУМОВА ДО ПЕРВИННОЇ ПРОФІЛАКТИКИ АРТЕРІАЛЬНОЇ ГІПЕРТЕНЗЇ̈ У ПІДЛІТКІВ}

Стрімкий розвиток суспільства та його динамічні зміни потребують розвитку емоційного інтелекту людини для іiі самореалізації та успішної адаптації в суспільстві. Чітке окреслення розроблених аспектів стосовно емоційного інтелекту (ЕI) може бути передумовою до первинної профілактики артеріальної гіпертензії (АГ). Профілактика артеріальної гіпертензії надзвичайно актуальна в сучасній медицині, оскільки серцево-судинні захворювання є найбільш розповсюдженою причиною смерті у світі. Кожен рік хвороби серця забирають 17 мільйонів життів. В Україні це, як і раніше, причина 63\% смертей. Серцево-судинні захворювання має кожен другий українець. На існування факторів ризику, що є причиною СС3, можна впливати через їх профілактику завдяки контролю за цими факторами . Методи, що застосовують для профілактики серцево-судинних захворювань, поділяють на первинні та вторинні.

Первинна профілактика включає:

- контроль надлишкової ваги;

- припинення вживання алкоголю та тютюну;

- контроль артеріального тиску (АТ), холестерину та глюкози в крові; 
- підвищення фізичної активності;

- уникання стресів, уміння справлятися з ними.

Вторинна профілактика включає застосування медичної терапії.

Стрес, хронічні хвороби відіграють важливу роль у появі артеріальної гіпертензії та іï ускладнень. Вплив на психологічні та стресові фактори дозволяє покращити якість первинної та вторинної профілактики АГ.

Значну роль у реалізації чинників ризику артеріальної гіпертензії в сучасному суспільстві відіграє реакція організму на зовнішні подразники та його можливість уникати дії небезпечних чинників довкілля шляхом розвитку самосвідомості й усвідомлення цінності власного здоров'я, саме цим і обумовлена актуальність проведеного нами дослідження.

Мета дослідження: визначити рівень емоційного інтелекту здорових учнів та учнів з артеріальною гіпертензією, який є передумовою до первинної профілактики даного патологічного стану.

Досягнення поставленої мети передбачає розв'язання таких дослідницьких завдань:

1) проаналізувати різні методи в науковій літературі з метою виділення основних складових ЕI;

2) на основі виділених основних складових ЕI визначити методики для його вивчення;

3) за допомогою визначених методик розкрити вплив емоційного інтелекту на функціональний стан серцево-судинної системи;

4) провести дослідження артеріального тиску, ЧСС у підлітків Полтавської гімназії №6 віком 15-16 років;

5) обгрунтувати вплив здорового способу життя як одного 3 факторів зміцнення психофункціонального стану ССС у підлітків і популяризувати здоровий спосіб життя.

Об’скт дослідження: ЕІ учнів 15-16 років Полтавської гімназії №6.

Предмет дослідження: аналіз взаємозв'язку емоційного інтелекту із функціональним станом серцево-судинної системи учнів.

Основні методи дослідження: теоретичний; статистичний метод; якісний та порівняльний аналіз; метод Н. Г. Короткова для визначення АТ; індекс Робінсона для визначення резервних можливостей ССС; аналіз й узагальнення наукової літератури із досліджуваної теми.

\section{Методики дослідження:}

1. Международный образовательный проект «Психология без границ» тест «Конструктивный рисунок человека из геометрических форм»;

2. тест «Струпа».

У дослідженні брали участь 47 учнів Полтавської гімназії № 6 серед яких 22 хлопчики та 25 дівчаток. Проведене дослідження виявило, що у піддослідних емоційний інтелект різний відповідно до віку та психоемоційного навантаження.

У певної кількості дітей (відповідно до проведеного психологічного тесту «Конструктивный рисунок человека из геометричних форм») виявлено високий рівень емоційного інтелекту, що становить лише 19\% від загальної кількості (Рис.1).

Середній рівень ЕІ виявлено в 43\% дітей, що вказує на причину нездатності розуміти та контролювати власні емоції.

Низький рівень ЕI виявлено у $38 \%$ школярів. Низький рівень ЕI засвідчує нездатність дітей розуміти й керувати як своїми емоціями, так і емоціями інших дітей. Водночас результати тестування засвідчують те, що підлітки перебувають у постійній психологічній напрузі. 
Під час проведення дослідження спостерігалося нервове збудження в деяких дітей, тому цим підліткам було запропоновано відвідати шкільного психолога та звернути увагу на своє ставлення до навчального процесу, харчування, а також активного відпочинку.

Отже, дослідження показників психосоматики та семіотики учнів Полтавської гімназії №6 дає нам можливість визначити рівень емоційного інтелекту в залежності від віку.

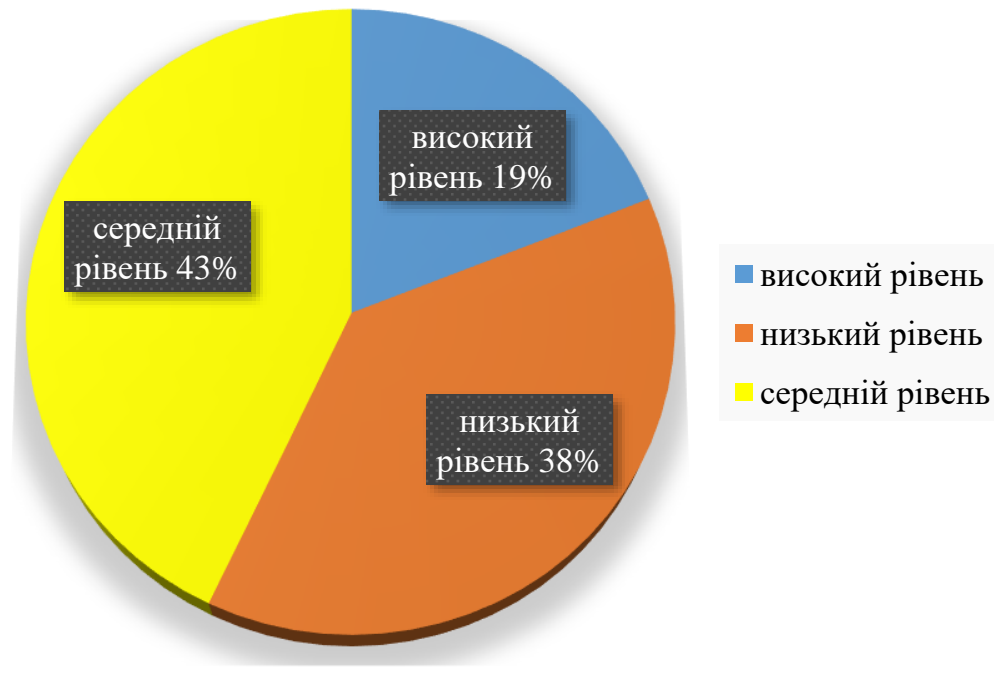

Рис.1. Відсоткове співвідношення показників ЕI у дітей К3 «Полтавська гімназія №6»

Під час дослідження у піддослідної групи, що складалася з 47 дітей з яких 243 АГ і 23 здорових ми отримали такі результати:

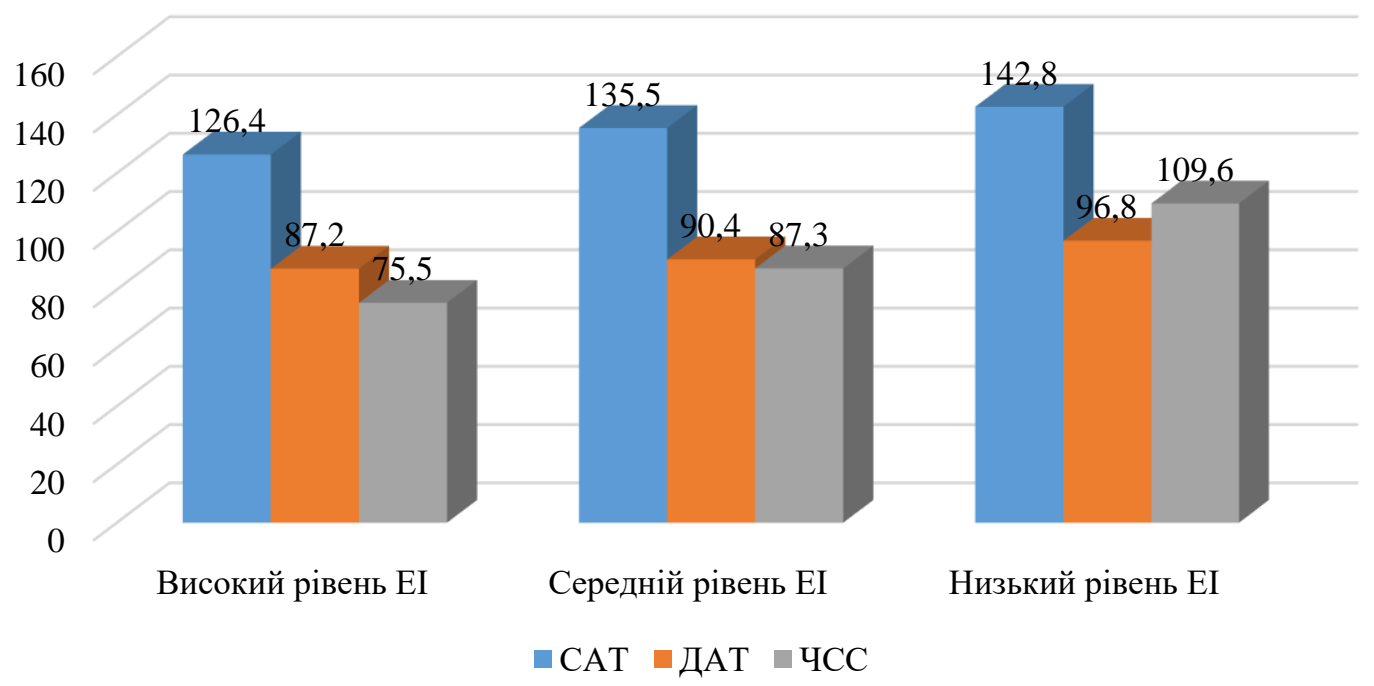

Рис.2. Показники ССС перед тестом «Струпа» у дітей з різним рівнем ЕI

У дітей з високим рівнем ЕІ показники САТ, ДАТ та ЧСС знаходяться в межах норми. У дітей з низьким ЕІ показники САТ зросли на 12\%, ДАТ на $10 \%$ та ЧСС на $45 \%$ відповідно.

Дослідження показників серцево-судинної системи проводилося ще раз через 15 хв після тесту. 


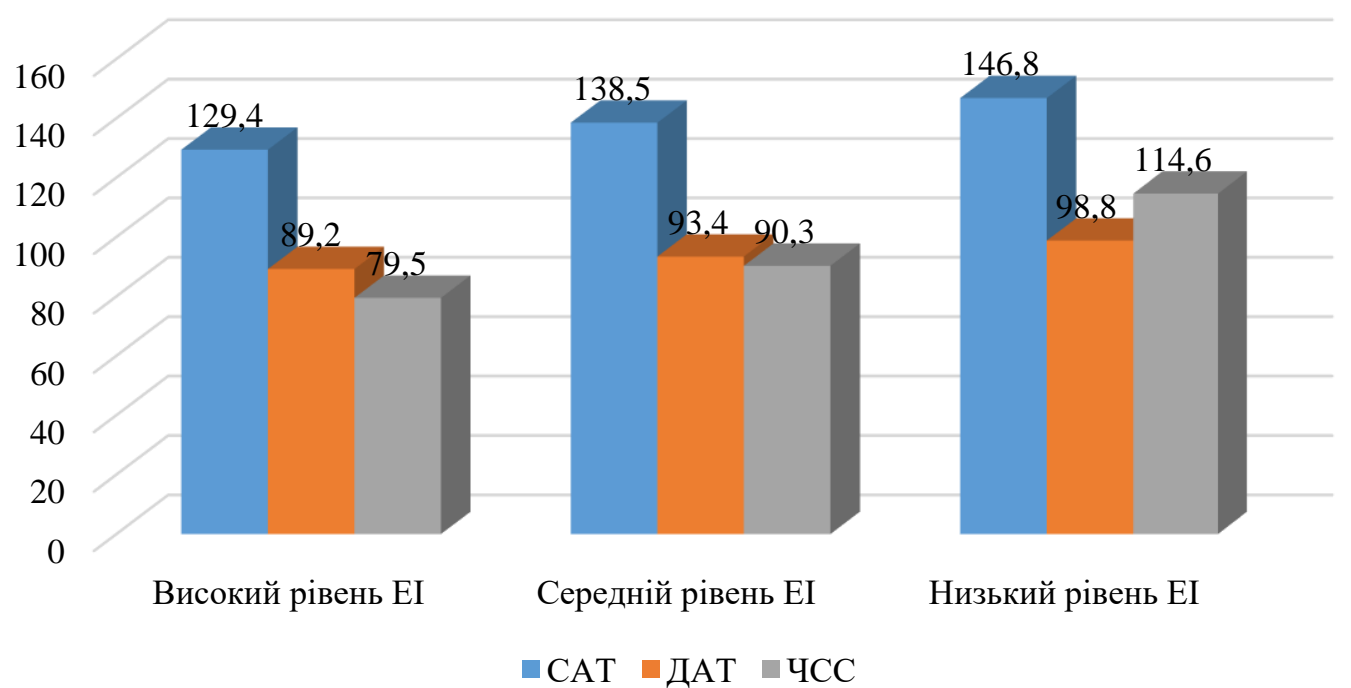

Рис.3. Показники ССС після тесту «Струпа» у дітей з різним рівнем ЕI

Показники дітей з високим рівнем ЕI коливаються в межах норми. У дітей 3 середнім рівнем ЕI можемо спостерігати тенденцію до пропорційного збільшення показників АТ та ЧСС, а у дітей з низьким рівнем показники АТ збільшилися на $2 \%$, а показники ЧСС збільшилися на 4\% у порівнянні з показниками перед тестом. Це вказує на те, що ЕІ має високу прогностичну цінність у первинній профілактиці АГ.

Порівнюючи показники ЧСС, СОК у стані спокою здорових дітей та учнів з АГ, можемо з упевненістю стверджувати, що здорові діти мають кращі показники (вони достовірні).

Результати показників індекс Робінсона у стані спокою, показують, що резервно-функціональні можливості серцево-судинної системи школярів різні.

Здорові діти мають найкращі показники роботи ССС, а також за результатами тесту відповідають I, II, VI, VII, VIII типам, які вказують на високий та середній рівень ЕІ. Так у 9-ти та 14-ти дітей, що становить 19\% та 30\% (Рис.2). показники ЧСС здорових дітей наростають пропорційно, на відміну від дітей з АГ.

На початку тесту показники САТ, ДАТ у піддослідних із АГ достовірно змінювалися, на відміну від здорових дітей. Зміна показників СОК спостерігалася тільки у дітей з АГ, які відповідають III, IV, V типам EI, що доводить їх низький рівень емоційного розвитку у порівнянні з здоровими учнями. У здорових дітей достовірно змінився IP. Коефіцієнт витривалості змінюється, хоча знаходиться в межах норми.

Перед тестом та після достовірно змінюються показники ЧСС, САТ, ДАТ у дітей з АГ. Зміна показників ІФЗ перед тестом, та після тесту вказує на низькі показники адаптації серцево-судинної системи підлітків. На слабкі аеробні можливості серцево-судинної системи дітей з АГ у порівнянні зі здоровими підлітками вказують достовірно змінені показники IP під час тесту.

Дослідження показників серцево-судинної системи проводилося через 15 хв після тесту.

Отже, у результаті проведених досліджень 3'ясовано, що в умовах елементарного стрес фактору (тест Струпа) в дітей з АГ і здорових відбувається активізація кровоносної системи, зміна показників роботи серцево-судинної системи відбувається по-різному. У здорових учнів показники серцево-судинної системи у стані спокою, перед тестом та після нього є кращими, про що свідчить нормальний функціональний стан серцево-судинної системи, на відміну від дітей 3 
АГ, у яких негативні зміни викликані емоційним напруженням, що є передумовою до появи АГ і можуть призвести до тяжких порушень із боку роботи серцевосудинної системи.

Отже, поєднання результатів Ідеографічного тесту 3 дослідженням серцевого ритму дає можливість атестувати не тільки показники рівня емоційного стану i когнітивної функції учня, але й реакції регуляторних систем організму.

У 47 учнів віком 15-16 \pm 0,25 років проводилося дослідження артеріального тиску. Участь брало 22 хлопчики та 25 дівчаток. Дослідження показало збільшення систолічного, та діастолічного артеріального тиску відповідно до наявності змін у роботі серцево-судинної системи .

Під час дослідження АТ у 10 ти дітей 15-ти років було виявлено підвищений рівень артеріального тиску, що становив 139,7/96,9 - 143,0/90,0 мм.рт.ст. Така ж ситуація спостерігалася і в 14-ти дітей 16-ти років, де артеріальний тиск становив 140,9/101,9 - 145,0/90,0 мм.рт.ст., протягом місяця проводячи повторні дослідження учнів з підвищеним АТ - показники не змінювались. Отже, можна стверджувати, що у 24 піддослідних із $47 є$ АГ.

Маємо таку загальну картину щодо показників АТ: у здорових підлітків 15 років систолічний артеріальний тиск становив 119,0 - 120,8 мм.рт. ст. У підлітків 16 років рівень АТ дещо зростає на (1,9 мм.рт.ст.), що відповідає 120,9 - 122,8 мм. рт. ст. У підлітків 15 років з АГ показник САТ становив 138,1- 141,1 мм. рт.ст., а у підлітків 16 років з АГ показники дорівнювали 143,1-146,0 мм. рт. ст. Показники ДАТ у здорових підлітків 15 -ти років становили 71,3 - 75,7 мм. рт. ст., а у підлітків 3 АГ - 93,1 - 94,0 мм. рт. ст.; показники ДАТ у здорових 16-ти річних підлітків показували 81,1 - 83,3 мм.рт.ст., а у їх однолітків з АГ дорівнювали 98,9 - 105,3 мм.рт.ст. Дані показників АТ минулого року тієї самої піддослідної групи були наступні. У 14 - ти дітей 14 років з АГ, АТ становив 135.0/91.3 - 136.0/94 мм.рт.ст., а у 10-ти дітей 15-ти років з АГ, АТ дорівнював 137.5/93.1 - 140.5/93.5 мм.рт.ст.

Отже, збільшення показників САТ, ДАТ у дітей 16 років $є$ наслідком довготривалого стресу. Таким чином, зміна показників артеріального тиску у здорових дітей і дітей з АГ відбувається по-різному.

З учнями, у яких виявили підвищений АТ, провели бесіду щодо візиту до лікаря (кардіолог), також звернули увагу на розвиток та формування соціально адаптованих поведінкових стратегій у взаємодії з соціумом.

Висновки. Високий рівень емоційного інтелекту в підлітків сприяє результативності первинної профілактики артеріальної гіпертензії, зокрема відмову від шкідливих звичок, достатнє фізичне навантаження, правильне харчування, контроль артеріального тиску. Зменшення чутливості до стресу в дітей може покращити якість первинної профілактики артеріальної гіпертензії. Після виконання завдань поставлених для досягнення мети, нами зроблено наступні висновки.

- Встановлено, що низький рівень емоційного інтелекту (ЕI) у підлітків впливає на зниження резервних можливостей серцево-судинної системи, особливо в тих, які мають порушення в режимі харчування, ведуть пасивний спосіб життя, мають шкідливі звички.

- Визначено, що в умовах психоемоційного навантаження робота серцевосудинної системи учнів активізується, показники цієї системи змінюються порізному. У школярів із низьким рівнем емоційного інтелекту ЕI показники ЧСС, САТ, ДАТ - збільшуються, а показники ПТ, СОК - зменшуються.

- Зміна показників ІФЗ після проведення тесту «Струпа» підтверджує, що підлітки мають низькі адаптаційні можливості роботи серцево-судинної системи; зміна показників IP свідчить про низький резерв аеробних можливостей організму школярів. 
- Підлітки, які мають кращі показники емоційного, соціального, естетичного та фізичного розвитку менша схильність до порушень роботи серцево-судинної системи.

- Доведено, що школярі, які не дотримуються правил і норм здорового способу життя, соціально не активні, мають зниження резервних можливостей серцевосудинної системи.

На основі результатів дослідження нами були створені та поширені пам'ятки про норми здорового способу життя. Розвиток емоційного інтелекту - це гарна профілактика артеріальної гіпертензії в умовах сучасного навчально-виховного процесу шкіл XXI століття.

\section{Список використаних джерел:}

1. Бибарсова Н. В. Оптимизация семейного самоопределения посредством развития эмоционального интеллекта юношей и девушек. Вестник Челябинского гос. пед. ун-та. 2014. № 7. C. $34-40$.

3. Блинова О.Є. Роль соціальних стереотипів у становленні світоглядних орієнтацій особистості зрілого віку / О.Є. Блинова // Психологія і особистість : наук. журн. - Полтава : Полтавський національний педагогічний університет імені В.Г. Короленка, 2015. - №2(8). - С. 65 - 70.

4. Блинова О.С. Соціально-психологічні чинники подолання кризи ідентичності осіб зрілого віку / О.Є. Блинова // Особистість як суб'єкт подолання кризових ситуацій: психологічна теорія і практика : монографія / За ред. С.Д. Максименка, С.Б. Кузікової, В.Л. Зливкова. - Кн. 2. - Суми : Вид-во СумДРУ ім. А. С. Макаренка, 2017. - С. $162-180$.

5. Блинова О.С. Соціокультурні та психологічні вектори становлення особистості : монографія / від. ред. О.С. Блинова. - Херсон : Видво ФОП Вишемирський, 2018. - С. 6-29.

6. Богучарова О.І. Практика психологічного супроводження здоров'я як посилення суб'єктності особистості / О.І. Богучарова // Теоретичні і прикладні проблеми психології : зб. наук. праць Східноукраїнського національного університету ім. В. Даля. - № 3(38). - Сєвєродонецьк : Вид-во СНУ ім. В. Даля, 2015. - С. $454-462$.

7. Бочар О. М. особливості перебігу та оптимізація терапії у пацієнтів з артеріальною гіпертензією, поєднаною з ожирінням та неалкогольною жировою хворобою печінки. Івано-Франківськ, 2018. C. 1

8. Ващенко І.В. Досвід міждисциплінарного дослідження розвитку цілісної особистості в контексті соціально-економічних криз / І.В. Ващенко, О.І. Власова, І.В. Данилюк, В.Л. Щербина // Психологія і особистість. - 2016. - № 2 (10). - Ч. 1. - С. 116 - 127.

Лигирда Олександра Вікторівна, здобувач медичного факультету Ужсгородський національний університет, Украӥна

Немеш Іван Михайлович, здобувач медичного факультету

Ужгородський національний університет, Україна

Науковий керівник: Ростока Лариса Михайлівна, к.мед.н., доц. кафедри біохімії, фармакології та фізичних методів лікування медичного факультету Ужгородський національний університет, Украӥна

\section{МЕТАБОЛІЧНИЙ СИНДРОМ - ПРОБЛЕМА ХХІ СТОЛІТТЯ}

Мета. Розглянути основні компоненти метаболічного синдрому з позицій патогенетичних механізмів. Роль дисфункції адипокінів у формуванні артеріальної гіпертензії, інсулінорезистентності, дисліпідемії.

Матеріали та методи дослідження. Використано бібліосемантичний метод та контент-аналіз літератури відносно питань нових поглядів на патогенез 
метаболічного синдрому, а також роль адипоцитів, як фактора дисметаболічного процесу та оксидативного стресу при МС.

Результати. У сучасних умовах надзвичайно зріс інтерес до проблеми метаболічного синдрому (МC) у всіх областях клінічної медицини, так як компоненти даного комплексу клініко-біохімічних порушень $\epsilon$ факторами ризику розвитку станів і захворювань 3 високою частотою летальних випадків [4,9]. До МС можна віднести всі захворювання, при яких має місце інсулінорезистентність: ожиріння, інсулінонезалежний цукровий діабет (ІНЦД), артеріальна гіпертензія (AГ), ішемічна хвороба серця (IXC) $[1,8]$. В даний час МС визначений як пандемія XXI століття. Поширеність МС становить 10-40\% і залежить від статі, віку, етнічної приналежності і використовуваних критеріїв діагностики, причому його найбільша поширеність відзначається в економічно розвинених країнах. У країнах Західної Європи і США поширеність МС становить в середньому 25-35\% [7,9].

Відповідно до сучасних уявлень, до МС відносять АГ, дисліпідемію, атеросклероз (АC) та IXC, а також ІНЦД [4]. Таке об'єднання підкреслює наявність загальних закономірностей в розвитку цих захворювань і відкриває нові можливості в їх профілактиці і лікуванні. Виділяють повну і неповну форми МС. Наявність 2-3 складових свідчить про неповну форму, більше 4 порушень - про повну форму МС [4]. Відповідно до сучасних уявлень, обов'язковим критерієм МС є центральний тип ожиріння (окружність талії у чоловіків $>94 \mathrm{~cm}$, у жінок $>80 \mathrm{~cm}$ ) $[5,6]$. В даний час загальна кількість дорослих в світі, які страждають на ожиріння, за даними різних літературних джерел, становить від 1,1 до 1,7 мільярдів люлей [5,4]. Згідно 3 останніми підрахунками, при збереженні існуючих темпів зростання захворюваності, до 2025 року в світі буде налічуватися більше 300 млн. чоловік 3 цим діагнозом [5,7].

В епідеміологічних дослідженнях показано, що у хворих з надмірною масою тіла частіше розвиваються захворювання опорно-рухового апарату, гепатобіліарної зони, рак легенів, рак молочної залози, рак тіла матки та яєчників [2,5,6]. На тлі ожиріння у жінок досить часто спостерігається порушення оваріальноменструальної функції і безпліддя [2,7]. До теперішнього часу немає єдиної думки про першопричину метаболічних порушень в патогенезі МС, який викликається поєднанням генетичних факторів i способу життя. Одні автори розглядають інсулінорезистентність (IP) [3,8], інші - ожиріння [5,6] як основну патогенетичну ланку, що призводить до подальшого розвитку метаболічних порушень. Існує гіпотеза, згідно з якою причиною IP, гіперінсулінемії (ГІ) та інших метаболічних порушень $є$ центральний тип ожиріння [6]. Зниження фізичної активності і надмірне споживання з їжею насичених жирів та вуглеводів є найбільш важливими факторами зовнішнього середовища, які сприяють розвитку МС [5]. При гіподинамії сповільнюється ліполіз і утилізація тригліцеридів (ТГ) в м'язовій і жировій тканині [5]. У міру збільшення маси жиру в організмі збільшуються розміри жирових клітин - адипоцитів [6]. При цьому, чим більше розмір адипоцитів, тим менше він чутливий до інсуліну. Відповідно менше і стримуючий вплив цього гормону на процеси ліполізу. Результатом цього є підвищення рівня ТГ і ненасичених жирних кислот в крові [6]. Адипоцити вісцеральної жирової тканини секретують вільні жирні кислоти безпосередньо в ворітну вену печінки. Їх високі концентрації пригнічують поглинання інсуліну печінкою, що призводить до ГІ і відносної IP [4].

Однією з можливих причин розвитку МС у хворих абдомінальним ожирінням може бути порушення гормонального обміну. В останні роки велика увага дослідників приділяється ролі адіпокінів - гормонів, секретується жировою тканиною, дисбаланс яких може призводити до метаболічних порушень. У різних дослідженнях показано, щклітини вісцеральної жирової тканини виробляють фактор 
некрозу пухлин- $\alpha$, інтерлейкін-1, інтерлейкін-6, інтерферон-g, лептин, адипонектин, резистин і багато інших речовин, які беруть

участь у розвитку МС $[1,6]$.

Згідно 3 іншою гіпотезою, первинною ланкою патогенезу $\epsilon$ порушення вуглеводного обміну, яке раніше інших видів обміну змінюється під впливом зовнішніх факторів $[3,8]$. Висока глікемія викликає ГІ, як компенсаторну реакцію. При виснаженні адаптаційних можливостей ГІ сприяє підвищенню рівня вільних жирних кислот і глюкози, що призводить до розвитку IP [8]. ГI спочатку знижує чутливість, а потім блокує інсулінові рецептори, внаслідок чого глюкоза, яка надходиться з їжею та жири депонуються жировою тканиною, посилюючи IP. 3 іншого боку, гіперінсулінемія пригнічує розпад жирів, сприяючи прогресуванню ожиріння. Постійна ГІ виснажує секреторний апарат бета-клітин підшлункової залози, що призводить до порушення толерантності до глюкози [9].

До IP призводять надлишок жиру в організмі, надлишок жиру в їжі, гіподинамія та підвищення активності симпатичної нервової системи [8]. Втім, дуже часто ці причини виступають в поєднанні. Разом з тим поєднання гіподинамії і жирного харчування веде спочатку до розвитку ожиріння, яке в свою чергу призводить до розвитку МС[5].

В даний час не викликає сумніву роль спадкової схильності у формуванні МС [5]. У зв'язку з цим актуальним $\epsilon$ пошук інформативних генетичних маркерів, що дозволяють своєчасно виявити пацієнтів, що відносяться до групи високого ризику розвитку МС, і відповідно проводити превентивні заходи на доклінічній стадії синдрому. Разом з тим, роль генетичних факторів у розвитку

компонентів метаболічного синдрому неоднозначна, що говорить про значну роль факторів зовнішнього середовища, таких як перинатальний розвиток, структура харчування, ступінь фізичної активності, шкідливі звички, стресовий вплив в розвиток симптомокомплексу МС [4].

Сучасними дослідженнями встановлено, що не тільки тісний зв'язок між ожирінням і іншими компонентами МС, але і роль ожиріння, як фактора, що ініціює прояви МС [5,6,7]. Дослідження переконливо демонструють, що ожиріння часто передує формуванню інших компонентів МС [5,6]. Формування повного МС відбувається через поступове збільшення компонентів, його складових. У зв'язку 3 цим зростає інтерес вивчення не тільки повної форми, але і різних поєднань його компонентів.

Висновки. Таким чином, атерогенна дисліпідемія, гіперглікемія та гіперінсулінемія є первинними взаємозалежними складовими МС, які формують атеросклеротичне ураження судин, сприяють формуванню i/aбо прогресуванню АГ. Після встановлення ендокринологічної активності жирової тканини, ролі лептину, дисліпідемія відступає на нижчу сходинку. В основі стають адипоцитокіни інсуліносенситайзери, і згідно з якими не зміни енергетичного субстрата перебудови адипоцитів, а вплив на організм сигнальних молекул, що виробляються ліпоцитами, $\epsilon$ основою формування дисметаболічних порушень компонентів МC, які $\epsilon$ взаємообтяженими "порочними" ланками патологічного процесу.

\section{Список використаних джерел:}

1. Александров О. В., Альохіна Р. М., Григор 'єв С. П. (2006) Метаболічний синдром. Рос. мед. журн., № 6, 50-55. Вилучено 3: https://cyberleninka.ru/article/n/metabolichniy-sindrom-adipokinovateoriya patogenezu/viewer

2. Бєляков Н. А. (2005) Метаболічний синдром у жінок (патофізіологія і клініка). Видавничий дім СПбМАПО, 434-440. Вилучено 3: https://www.bsmu.edu.ua/blog/3446-metabolichniy-sindrom-yakmediko-sotsialna-problema/.

3. Буеверова Е. Л. (2009) Инсулинорезистентность - ключова ланка порочного кола метаболічного синдрому. Російські медичні вісті., Т. 14, № 4, 61-64. Вилучено 3: http://www.irbis-nbuv.gov.ua/cgi- 
bin/irbis_nbuv/cgiirbis_64.exe?C21COM=2\&I21DBN=UJRN\&P21DBN=UJRN\&IMAGE_FILE_DO WNLOAD=1\&Image_file_name=PDF/Uzn_2012_2-3_32.

4. Бутрова С. А. (2001) Метаболічний синдром: патогенез, клініка, діагностика, підходи до лікування. Рос. межд. журн., Т. 9., 56-60. Вилучено з: http://jcees.endocenter.kiev.ua/article/download/83259/78677.

5. Гінзбург М. М., Крюков Н. Н. (2008) Ожиріння та метаболічний синдром. Медпрактика, 124 -128. Вилучено 3: https://pidruchniki.com/90284/meditsina/metabolichniy_sindrom.

6. Дідів I. I. (2006) Жирова тканина як ендокринний орган. Ожсиіння $і$ метаболіз, № 1, 7-11.

7. Завалко А. Ф. (2011) Особливості жирового і вуглеводного обміну в послеабортном періоді у жінок, схильних до метаболічного синдрому. Вісник нових медичних технологій, Т. 18, № 3, 1314. Вилучено 3: http://strazhesko.org.ua/upload/2014/02/20/metodichka_a5_-n1402-_ua.

9. Квіткова Л. В., Єленський Т. С. (2008) Інсулінорезистентність та фактори, що ії визначають. Сибірський медичний журнал, Т. 80, № 5, 12-16.

10. Кузьміна О. Ю., Лотків В.С. (2008) Епідеміологія метаболічного синдрому в клініці професійних хвороб. Известия Самарського наукового ичентру РАН, Т. 2.,75-79.

Мимренко Анастасія Анатоліївна, студентка 5 курсу Медичного факультету ДВНЗ "Ужгородський національний університет", Украӥна

Кузьмак Мар'яна Василівна, студентка 5 курсу Медичного факультету ДВНЗ "Ужсгородський національний університет", Украӥна

Науковий керівник: Ростока Лариса Михайлівна, доцент кафедри біохімії, фармакології, фізичних методів лікування з курсом аналітичної медицини медичного факультету ДВНЗ "Ужггородський національний університет", Україна

\section{ПЕРЕВАГИ ВИКОРИСТАННЯ ГЛІКЕМІЧНОГО ІНДЕКСУ ДЛЯ СКЛАДАННЯ ДІЕТ У ПОРІВНЯННІ 3 КАЛОРІЙНІСТЮ ЇЖІ}

Вступ. Для характеристики енергетичної цінності продуктів харчування в даний час найчастіше використовуються наступні показники: калорійність, поділ на "швидкі та повільні вуглеводи", хлібні одиниці (XО) та глікемічний індекс (ГІ). Два останні найбільш часто використовуються при складанні дієт, особливо для хворих із синдромом інсулінорезистентності [1]. ХО - це міра, яка використовується для оцінки кількості вуглеводів у продуктах харчування. 1 ХО вважається рівною 12 г цукру або 25 г білого хліба. Напроти, ГІ - це показник, який відображає, з якою швидкістю той чи інший продукт підвищує рівень глюкози в крові. За еталон була взята глюкоза, чий ГІ становить 100, а рівень ГІ інших продуктів вираховується по відношенню до неї. Продукти, глікемічний індекс яких низький, складаються 3 повільних вуглеводів, які повільно розщеплюються в травному тракті, володіють низькою усмоктуваністю глюкози в кров. Навпаки, продукти з високим глікемічним індексом швидко збагачують кров цукром, який повільно згодом виводиться 3 організму. Такі продукти містять швидкі вуглеводи. Глікемічний індекс повільних вуглеводів не перевищує 40, швидких вуглеводів - перевищує 70. Існує і середній глікемічний індекс від 40 до 70, продукти з вмістом якого слід все ж відносити до групи ризику. Замінюючи продукти з високим ГІ на продукти з низьким ГІ, ми можемо регулювати свою вагу впродовж тривалого часу і рідше застосовувати жорсткі дієти для схуднення [2].

Мета роботи. Оцінити нутритивний статус та соматометричні дані досліджуваної вибірки людей у взаємозв'язку з ГІ та калорійністю вживаних ними продуктів. 
Матеріали і методи дослідження. Проведено опитування добровольців за допомогою спеціальних анкет $(\mathrm{n}=105)$. Похідними показниками даних анкети стали середній ГІ (сГI) та середня калорійність (сК) вживаних продуктів у перерахунку на 100 г продукту, а також усереднені ГІ та калорійність за однин прийом.

Результати доссліджень. ХО - це міра, яка використовується для оцінки кількості вуглеводів у продуктах харчування. 1 ХО вважається рівною 12 г цукру або 25 г білого хліба. Для хворих на ЦД рекомендованим є вживання не більше 25 XО на добу або 6-7 XО за прийом їжі. Напроти, ГІ - це показник, який відображає, 3 якою швидкістю той чи інший продукт підвищує рівень глюкози в крові. За еталон була взята глюкоза, чий ГІ становить 100, а рівень ГІ інших продуктів вираховується по відношенню до неї. Щодо "швидких та повільних вуглеводів", то для їх поділу використовують той же самий ГI, а саме, якщо ГІ продукту $>70$, то його відносять до швидких, якщо менше 40 - до повільних. Тобто продукти, ГІ яких низький, складаються 3 "повільних вуглеводів", які повільно розщеплюються в травному тракті, володіють низькою всмоктуваністю глюкози в кров. Навпаки, продукти 3 високим ГІ швидко збагачують кров цукром, який повільно згодом виводиться 3 організму. Такі продукти містять швидкі вуглеводи. Далі наведена таблиця (табл. 1) величин ГІ деяких харчових продуктів і готових страв, але потрібно враховувати те, що ГІ одних і тих же продуктів може відрізнятися за рахунок способу приготування (сире, жарене, варене, парене, копчене тощо). Як видно з таблиці, ГІ деяких продуктів (вівсяна каша, гречка, рис) є високим, але їх часто рекомендують вживати при різних дієтах. Це зумовлено тим, що глікемічний індекс вимірюється після того, коли людина з'їдає стільки продукту, щоб отримати 50 г вуглеводів. Наприклад, ГІ гарбуза становить 75 і щоб підняти рівень глюкози в крові до табличного глікемічного показника, потрібно за один прийом з'їсти 770 г гарбуза, а це відбувається поза експериментом далеко не кожний день. Також потрібно враховувати і калорійність продукту, яка становить для того ж самого гарбуза тільки 193 ккал. Замінюючи продукти з високим ГІ на продукти з низьким ГІ, ми можемо регулювати свою масу впродовж тривалого часу та рідше застосовувати жорсткі дієти для схуднення.

Таблиия 1

\begin{tabular}{|l|c|l|c|}
\multicolumn{1}{|c|}{ Продукт/Страва } & Глікемічний індекс & \multicolumn{1}{c|}{ Продукт/Страва } & Глікемічний індекс \\
\hline Хліб білий & $\mathbf{8 5}$ & Рис & $\mathbf{6 0}$ \\
\hline Хліб чорний & $\mathbf{6 5}$ & Вівсяна каша & $\mathbf{8 5}$ \\
\hline Вівсяне печиво & $\mathbf{7 9}$ & Ясчня & $\mathbf{0}$ \\
\hline Булочки & $\mathbf{8 8}$ & Плов & $\mathbf{7 0}$ \\
\hline Піца & $\mathbf{6 0}$ & Бутерброд & $\mathbf{9 0}$ \\
\hline Сосиски & $\mathbf{2 8}$ & Вареники & $\mathbf{7 0}$ \\
\hline Ковбаса варена & $\mathbf{5}$ & Картопляне пюре & $\mathbf{9 0}$ \\
\hline Сало & $\mathbf{0}$ & Борщ & $\mathbf{3 0}$ \\
\hline Свинина & $\mathbf{0}$ & Бульйон & $\mathbf{0}$ \\
\hline Курятина & $\mathbf{5}$ & Омлет & $\mathbf{0}$ \\
\hline Риба (скумбрія, & $\mathbf{0}$ & Котлети & $\mathbf{5 0}$ \\
\hline следь) & $\mathbf{3 0}$ & Пельмені & $\mathbf{6 0}$ \\
\hline Молоко коровяче & $\mathbf{0}$ & Макарони & $\mathbf{6 0}$ \\
\hline Сир & $\mathbf{1 5}$ & Салат "Олів'є" & $\mathbf{5 2}$ \\
\hline Масло вершкове & $\mathbf{1 5}$ & Салат "Цезар" & $\mathbf{3 5}$ \\
\hline Кефір & $\mathbf{8 5}$ & Молочний шоколад & $\mathbf{7 0}$ \\
\hline Морква & $\mathbf{1 0}$ & Цукор білий & $\mathbf{7 0}$ \\
\hline Помідори & $\mathbf{1 0}$ & Мед & $\mathbf{9 0}$ \\
\hline Капуста & $\mathbf{9 0}$ & Морозиво & $\mathbf{7 0}$ \\
\hline Картопля сира & $\mathbf{7 8}$ & Цукерки карамельні & $\mathbf{8 0}$ \\
\hline Гречка & & &
\end{tabular}




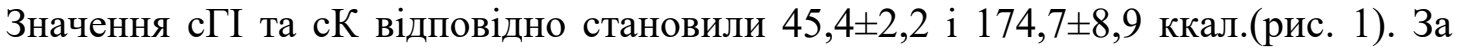
даними показниками досліджувану вибірку було розділено на 3 групи: питома вага добровольців із низьким сГІ становила $34 \%$, середнім - 65\%, високим - $1 \%$. Не було знайдено кореляції між сГІ та сК. Це може свідчити, що дані параметри відображають абсолютно різні характеристики продуктів по відношенню до їх використання для складання дієт. Питома вага осіб за переважним вживанням продуктів із певним ГІ становить: $34 \%$ - низький; 65\% - середній; $1 \%$ - високий. Саме різкий підйом глікемії $є$ вирішальним у виникненні ожиріння та підвищення толерантності до глюкози, оскільки інсулін у даному випадку стимулює синтез жиру із глюкози. Крім того, періодична гіперглікемія призводить до гіперінсулінемії, яка також може мати негативні наслідки.

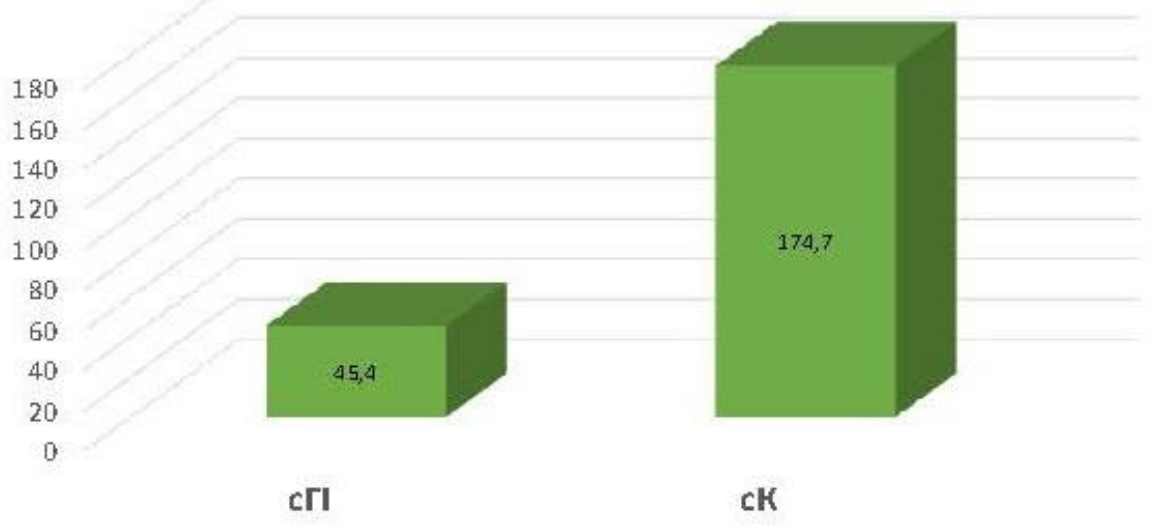

Рис. 1. Співвідношення сГІ до сК серед усіх добровольців

За результатами епідеміологічних досліджень, що проводились у Парижі та Гельсінкі встановлено, що задовго до розвитку ішемічної хвороби серця IXC у людей спостерігалася гіперінсулінемія, як базальна, так і постпрандіальна (після вживання їжі). Це свідчило по те, що між гіперінсулінемією та (IXC) існує певний зв’язок (рис. 2).

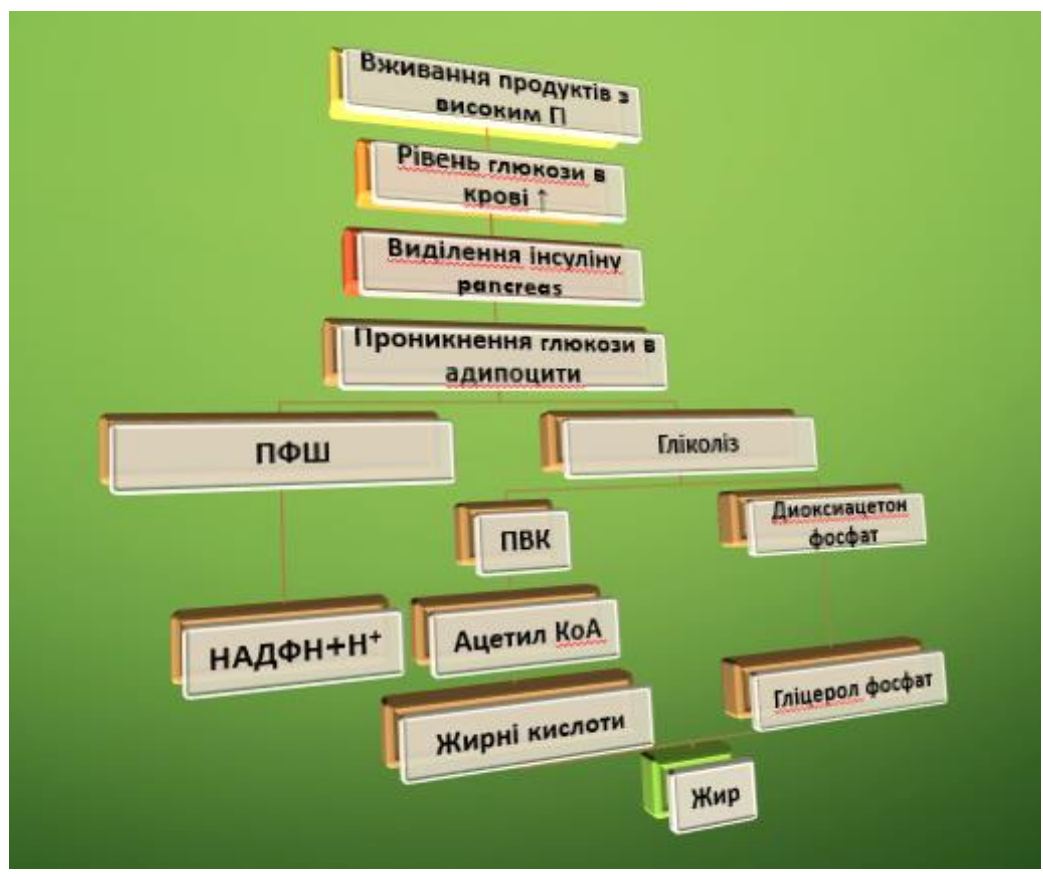

Рис. 2. Зв'язок гіперінсулінемії з розвитком IXC 
Одним з пояснень цього зв'язку є специфічний вплив інсуліну і стану тканинної інсулінорезистентності на синтез і транспорт ліпідів. Окрім цього, інсулін, який інколи називають атерогенним гормоном, здатний прискорювати формування атеросклеротичних бляшок і на тканинному рівні. Концентрація інсуліну в плазмі крові безпосередньо впливає на основні компоненти атеросклеротичної бляшки: ліпідні маси, колаген, пінисті макрофаги і проліферуючі судинні гладком'язові клітини. Спостерігаються проліферація клітин, збільшення синтезу ендогенного холестерину та тригліцеридів.

Стимулювальний вплив інсуліну на синтез ліпідів обумовлений його дією на ліпогенні ферменти: глюкозо-6-фосфатдегідрогеназу і 3-гідроксиацетил-КоАдегідрогеназу. Також виявлено, що інсулін посилює синтез колагену - одного 3 основних складових атеросклеротичної бляшки. Калорійність їжі - кількість енергії, яка утворюється при окисненні жирів, білків, вуглеводів, що міститься у продуктах харчування, і витрачається на фізіологічні функції організму. Нами було визначено необхідну кількість калорій на добу для опитуваних осіб. Даний показний враховує величину основного обміну та коефіцієнт фізичної активності. Цікавим є той факт, що фактична калорійність їжі за день була приблизно у 1,5 разів менша за необхідну, що відображає недосконалість даної величини.

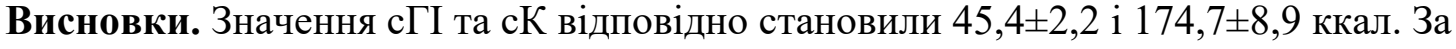
даними показниками досліджувану вибірку було розділено на 3 групи: питома вага добровольців із низьким сГІ становила $34 \%$, середнім - 65\%, високим - $1 \%$. Не було знайдено кореляції між сГІ та сК. Це може свідчити, що дані параметри відображають абсолютно різні характеристики продуктів по відношенню до їх використання для складання дієт. Саме різкий підйом глікемії $\epsilon$ вирішальним у виникненні ожиріння та підвищення толерантності до глюкози, оскільки інсулін у даному випадку стимулює синтез жиру із глюкози. Цікавим $є$ той факт, що фактична калорійність їжі за день була приблизно у 1,5 разів менша за необхідну, що відображає недосконалість даної величини. Поділ на "швидкі та повільні вуглеводи" та ХО, на нашу думку, повинні вважатися похідними ГІ. Отже, ГІ є еталонним параметром, який дає змогу оцінити вплив їжі (як фактора) на енергетичний, вуглеводний та ліпідний обміни.

\section{Список використаних джерел:}

1. Кручаниця М. І., Миронюк І.С., Розумикова В.В., Брич В.В., Кіш В.П. (2019). Основи харчування. Ужгород: Говерла

2. Сокрута В.М. (2013). Спортивна медицина: Підручник для тудентів і лікарів. Донецьк: Каштан 
Кирилова С.I., здобувач медичного факультету

Харківський національний університет імені В.Н. Каразіна, Украӥна

Вострокнутов І.Л., здобувач медичного факультету

Харківський національний університет імені В.Н. Каразіна, Украӥна

Науковий керівник: Кирилова О.О., канд. психол. наук, ст..наук.співроб.

ДУ «Інститут охорони здоров'я дітей та підлітків

Начіональна академія медичних наук Украӥни, Украӥна

\section{ПРИХИЛЬНІСТЬ ДО ЛІКУВАННЯ ПІДЛІТКІВ 3 ЦУКРОВИМ ДІАБЕТОМ І ТИПУ}

Кожного року в Україні постійно збільшується кількість хворих дітей та підлітків на цукровий діабет (ЦД) I типу. Це захворювання є одним 3 найтяжчих ендокринних захворювань, в розвитку якого певну роль відіграють фактори психологічної природи $[1,2]$. На розвиток ЦД впливають не тільки спадковість або зовнішні біологічні фактори середовища, але й індивідуальні психологічні особливості людини [3]. Психологічний фактор, що обумовлює успішність лікування ЦД є прихильність до лікування. Згідно з визначенням експертів ВООЗ (2003) під прихильністю хворого до лікування розуміють міру, до якої поведінка пацієнта (прийом медикаментів, додержання дієти тощо) відповідає призначеним медичним рекомендаціям [4]. Вона базується на якісному контакті між лікарем та хворим, на довірі хворого до лікаря, на тому, як роз'яснюються хворому мета та завдання лікування, та саме головне - на заходах самоконтролю пацієнта. Однією 3 актуальних проблем медицини є виявлення пацієнтів з низьким рівнем прихильності до лікування для оптимізації ресурсів системи охорони здоров'я через підвищення заходів самоконтролю [5].

Мета дослідження: вивчення особливостей прихильності до лікування підлітків із ЦД І типу різної статі в залежності від рівня глікемічного контролю (ГК).

Матеріали та методи дослідження. У дослідженні взяли участь 60 підлітків із ЦД I типу віком 12-18 років, що знаходилися на стаціонарному лікуванні в ендокринологічному відділенні клініки ДУ «ІОЗДП НАМН», з них 32 дівчини та 28 хлопців. Всі хворі мали достатній термін для психологічної адаптації до ЦД, мінімальний термін захворювання був 3 роки, максимальний - 16 (в середньому 6,9 років).

За рівнем НвА 1 як інтегрального показника компенсації вуглеводного обміну за рекомендаціями ISPAD (2011) хворі були розділені на три групи: з величиною $\mathrm{Hв}_{1 c}<7,5 \%$ - група оптимального глікемічного контролю, НвА 1 c $=7,5$ - 9 \% - група субоптимального глікемічного контролю, НвА1с > $9 \%$ - група глікемічного контролю високого ризику.

За рівнями контролю цукрового діабету оптимальний рівень ГК мали 28,3 \% підлітків (21,9 \% дівчат та 35,7 \% хлопців), субоптимальний рівень ГК мали 30 \% підлітків (37,5 \% дівчат та 21,4\% хлопців), в групу з високим ризиком ускладнень потрапили 41,7 \% підлітків (40,6 \% дівчат та 42,9 \% хлопців).

Для оцінки особливостей прихильності до лікування підлітків з ЦД І типу був використаний «Опитувальник на прихильність до лікування підлітка хворого на цукровий діабет» [6].

Встановлено, що достовірна більшість підлітків із ЦД І типу (65 \%) достатньо регулярно на протязі дня вимірюють рівень цукру в крові, тоді ж як $35 \%\left(\mathrm{p}_{\varphi} \leq 0,01\right)$ підлітків в деяких ситуаціях пропускають цю процедуру. Половина підлітків (50 \%) 
не завжди дотримується дієти або витримує регулярність режиму харчування. Та достовірна більшість підлітків $\left(73,3 \%\right.$ проти $\left.26,7 \%, \mathrm{p}_{\varphi} \leq 0,01\right)$ намагаються дотримуватися режиму інсулінотерапії. За гендерною ознакою достовірних відмінностей прихильності до лікування у підлітків із ЦД І типу не виявлено.

В залежності від рівня ГК встановлено, що у підлітків із оптимальним ГК майже третина $(29,4$ \%) забувають та пропускають вимірювання цукру, але ж достовірна більшість (70,6 \%) мають достатній рівень та роблять це регулярно і правильно. (табл.3). В групах підлітків із субоптимальним ГК та високим рівнем ускладнень ЦД тільки половина підлітків (50\% та 52 \%) регулярно і вірно вимірюють рівень цукру в крові.

Більшість підлітків, залежно від рівня компенсації, не дотримувалися режиму харчування. Так 58,8 \% підлітків із оптимальним ГК недостатньо витримували дієту та пропускали прийом їжі, 55,6 \% підлітків із субоптимальним ГК та 64 \% підлітків із високим рівнем ускладнень ЦД.

Встановлено, що у підлітків із оптимальним ГК лише 17,6\% забувають та пропускають введення інсуліну, а роблять це регулярно і правильно 82,4 \% підлітків цієї групи $\left({ }^{*} \mathrm{p}_{\varphi} \leq 0,05\right)$. В групі підлітків із субоптимальним ГК збільшується частка дітей, що нерегулярно вводять інсулін до 27,8 \%, намагаються дотримуватись режиму інсулінотерапії 72,2 \% підлітків. В групі підлітків із високим рівнем ускладнень ЦД фіксується найбільша частка дітей, що не дотримуються режиму введення інсуліна $\left(60 \%, * * p_{\varphi} \leq 0,03\right)$, та лише $40 \%$ намагаються регулярно вводити інсулін.

Висновки. Встановлено, що прихильність до лікування у підлітків із ЦД І типу не залежить від гендерного фактору; складова прихільності до лікування ЦД І типу у підлітків, яка найбільш порушується та недотримується - режим харчування; найбільше підлітків із низьким рівнем прихильності до лікування ЦД мають ГК 3 високим ризиком ускладнень. Отримані дані дають підгрунтя для формування програм медико-психологічного супроводу хворих підлітків для поліпшення формування їх довгострокової мотивації до самоконтролю ЦД І типу.

\section{Список використаних джерел:}

1. Дедов И.И., Кураева Т.Л., Петеркова В.А., Щербачева Л.Н. Сахарный диабет у детей и подростков. М., Универсум паблишинг, 2002. - 391 с.

3. Менделевич В.Д., Соловьева С.Л. Неврозология и психосоматическая медицина. - М., Медпресс информ, 2002. - 608 с.

4. Карвасарский Б.Д. Клиническая психология. Учебник. М., 2004 г.

5. Weir M., Maibach E., Bakris G. et al. Implications of the health and lifestyle and medication analysis for improving hypertension control // Arch. Intern. Med. - 2000. - Vol. 160. - P. 481-490.

6. 2007 European Society of Hypertension - European Society of Cardiology guidelines for management of arterial hypertension // J. Hypertension. - 2007. - Vol. 25. - P. 1105-1187.

7. Комплексна оцінка мотивації до самоконтролю у підлітків із цукровим діабетом I типу [Текст] : метод. рек. / ДУ «ОЗДП НАМН»; уклад. : О.О. Кирилова, О.А. Будрейко, С.О. Чумак // Український журнал дитячої ендокринології. - 2018. - № 2. - С. 33-41. 
Пелих Іван Миколайович, здобувач вищої освіти III курсу I медичного факультету

Харківський начіональний медичний університет, Україна

Науковий керівник: Черненко Інна Іванівна, к. мед. наук, с. викладач кафедри соціальної медицини та громадського здоров'я

Харківський національний медичний університет, Украӥна

\section{ПРОБЛЕМИ ДОКАЗОВОЇ МЕДИЦИНИ В УКРАЇНІ}

Приблизно до середини минулого століття діагностика та методи лікування хворих спирались на досвід більш старших лікарів, що не гарантувало отримання позитивного результаті в лікування, а навіть часто призводило до негативних наслідків. Ситуація не задовольняла ні пацієнтів ні лікарів і в 80-х роках XX століття були запропоновані нові підходи до діагностики та лікування. Новий метод включав такі постулати, що препарати які використовують мають бути ефективно дієвими, хірургічне втручання повинно мати мінімальний ризик та максимальну ефективність для пацієнта. Одним словом, даний підхід отримав назву - «доказова медицина» [1-3].

Весь Світ перейшов на стандарти доказової медицини, в Україні лише 20\% лікарів притримуються даних правил. Всі інші продовжують працювати по-старому, та навчати цьому молоде покоління лікарів.

Методики діагности та лікування в нашій країні змінюються дуже повільно, причиною цьому є:

1) Освіта медичних працівників в сфері статистичних обчислень - лікар не може об'єктивно оцінити ефективність використання певного лікарського препарату чи методики лікування.

2) Використання при лікуванні у більшості випадків українських аналогів препаратів, як не пройшли міжнародну перевірку, а тільки державну, в якій не включені великі рандомізовані дослідження, що знижує доцільність використання даного препарату.

3) Недостатне фінансування системи охорони здоров'я, через що пацієнти вимушені купувати дешевші вітчизняні аналоги для свого лікування.

4) Недосконалість законодавства, так як не має чітко прописаних мір покарання для лікарів за недотримання принципів доказової медицини у своїй практиці [3-5].

Насправді існує набагато більше проблем пов'язаних із впровадженням принципів доказової медицини в українську практичну медичну діяльність, але саме вирішення приведених основних проблем дозволить значно покращити якість вітчизняної медицини, зменшити час на діагностику та лікування.

\section{Список використаних джерел:}

1. Власов В. В. (2001) введення в доказову медицину. Медіа Сфера, м., 392 с.

2. Воробйов К. П. (2005a) доказова медицина - нова методологія медичної практики. Частина V. доказова медицина для лікаря-дослідника. Укр. мед. альманах, 4: 48-53.

3. Леонов В. П. (2006) навчання медиків статистиці: спроба системного підходу до проблеми. Міжнародний журнал медичної практики, 2: 17-22.

4. Уваренко А. Р. (2005 )о разработке и внедрении принципов доказательной медицины в Украине. Бюллетень ВАК Украины, 11: 26.

5. Чебраков Ю. В. (2000) методи системного аналізу в експериментальних дослідженнях. СПб, $114 \mathrm{c}$. 
Гордіснко Поліна Олексіївна, здобувач вищої освіти 1 медичного факультету Харківський начіональний медичний університет, Україна

Науковий керівник: Моїсеснко Тетяна Анатоліївна, канд. мед. наук, доцент кафедри внутрішньої медицини №3 та ендокринології Харківський національний медичний університет, Україна

\section{РЕТРОСПЕКТИВНИЙ АНАЛІЗ ПРИЧИН КЕТОАЦИДОЗУ У ХВОРИХ НА ІНСУЛІНОЗАЛЕЖНИЙ ЦУКРОВИЙ ДІАБЕТ У СТАДІЇ ДЕКОМПЕНСАЦІЇ}

Актуальність. Діабетичний кетоацидоз (ДКА) - це гостре ускладнення цукрового діабету (ЦД), яке характеризується різким підвищенням рівня глюкози та кетонових тіл у крові та розвитком метаболічного ацидозу, що призводить до порушення свідомості хворого і потребує екстренної госпіталізації $[1,2]$. Наразі тема ДКА $є$ досить актуальною проблемою сучасної медицини, адже за даними європейських досліджень смертність від цього гострого ускладнення ЦД складає 0,6-3,3\%. Не зважаючи на те, що хворі на ЦД навчені постійно відстежувати рівень кетонових тіл у сечі, ДКА є однією з причин госпіталізації хворих на ЦД $[1,3]$.

Мета. Провести ретроспективний аналіз причин виникнення ДКА у хворих на інсулінозалежний ЦД у стадії декомпенсації, що призвели до госпіталізації хворих.

Матеріали дослідження. Дослідження проводилося на базі ендокринологічного відділення Харківської обласної клінічної лікарні (ХОКЛ), проаналізували 32 історії хвороби пацієнтів, які були терміново госпіталізовані у стаціонар з ДКА у період з 2015 по 2020 рік. Серед них було 22 чоловіка (68,75\%) та 10 жінок $(31,25 \%)$, середній вік пацієнтів складав $39,2 \pm 5$ років. Середня тривалість захворювання становила $12,4 \pm 1,8$ років.

Результати дослідження. Для визначення рівня кетонових тіл при ДКА у хворих на догоспітальному етапі використовувались експрес тест-смужки для визначення концентрації кетонових тіл у сечі «Ацетонтест» 3 діапазоном чутливості 0-15 ммоль/л. За результатами ретроспективного аналізу ДКА у 6 хворих $(18,75 \%)$ був викликаний вживанням алкогольних напоїв, у 1 хворого $(3,125 \%)$ ДКА виник через вживання кортикостероїдів, у 12 хворих (37,5\%) ДКА був спричинений пропуском ін'єкції інсуліну або неправильним розрахунком дози інсуліну, у 8 хворих (25\%) причиною виникнення ДКА був сильний психологічний стрес. Причиною виникнення у 5 хворих $(15,625 \%)$ були розвиток супутніх захворювань: у 3 хворих - вогнищева пневмонія і у 2 хворих — загострення подагри.

Висновки. Отже, наявність навичок по самоконтролю кетонурії не дозволяє повністю уникати розвитку ДКА. Найбільш частими причинами виникнення ДКА $€$ стреси, вживання алкоголю, кортикостероїдів, пропуск ін'єкції інсуліну або введення неадекватної дози інсуліну та супутні захворювання. Попередження виникнення таких подій є важливим засобом забезпечення стабільної компенсації ЦД.

\section{Список використаних джерел:}

1. Shi L., Zhou L., Liu J., Ding Y., Ye X.H., Cheng J.L. (2020). Risk Factors of Ketosis in Obese KetosisProne Diabetic Patients: A Case-Control Study. Diabetes Ther.,11(4), 965-977.

2. Caines C. M., Shaw A., Solomon A. M. (2020). A project identifying potential risk factors leading to diabetic ketoacidosis in patients with type 1 diabetes treated with an insulin pump. Clin Med (Lond), 20 (2), 233-234.

3. Тишковский, С. В., Никонова, Л. В., Гулинская, О. В., \& Мартинкевич, О. Н. (2011). Диабетический кетоацидоз: этиопатогенез, анализ заболеваемости и поиск путей профилактики. Журнал Гродненского государственного медицинского университета, (1 (33)), 82-84. 
Бадалов Заур Адалят огли, здобувач вищої освіти медичного факультету Харківський начіональний медичний університет, Украйна

Науковий керівник: Боярський Мирослав Романович, канд. мед. наук, асистент кафедри «Гігієни та екології №1»

Харківський національний медичний університет, Україна

\section{ТЕНДЕНЦІЯ РОСТУ ПРОФЕСІЙНОГО ЗАХВОРЮВАННЯ СЕРЕД ПРАЦІВНИКІВ ХАРКІВСЬКОГО ТРАКТОРНОГО ЗАВОДУ}

Місто Харків $є$ важливим економічним, індустріальним центром сходу України, переважаючий потужною промисловою зоною. На Харківщині сконцентровано понад 760 промислових підприємств великого та середнього бізнесу, на яких працює близько 170 тис. чоловік [1]. Харківський тракторний завод займає почесне місце у виробництві, але професійна захворюваність залишається на високому рівні. Діагноз професійного захворювання було встановлено 122 працівників підприємства на 2019 рік тобто кількість постраждалих внаслідок розвитку професійних захворювань залишається високим.

Машинобудування $є$ однією з важливих галузей промисловості регіону, при цьому роботи важкої і дуже важкої категорії в даній галузі досягають 40\%. На підприємствах машинобудування, особливо тих, де використовується «застаріле» обладнання, зберігається високий рівень професійної захворюваності. При цьому в структурі захворюваності превалюють захворювання бронхо-легеневої системи (ХОЗЛ), сенсо-невральної приглухуватість, вібраційна хвороба, хвороби кістковом'язової та периферичної нервової систем [2].

Нами проаналізовані 120 історій хвороб працівників підприємства, що мають встановлений діагноз професійних захворювань. Серед постраждалих було поставлено 102 діагноза професійного захворювання бронхо-легеневої системи, 102 діагноза сенсо-невральної приглухуватості 2-4 ступеня, 31 випадок вібраційної патології, 47 випадків попереково-крижової радикулопатії, 1 випадок професійної інтоксикації, 5 випадок бронхіальной астми. Серед 102 постраждалих 3 діагнозом сенсо-невральної приглухуватості тільки 20 було виявлено з незначним зниженням слуху 2 ступеня. У більшості постраждалих (69) мало місце помірне зниження слуху (3 ступінь).

Звертає на себе увагу велика кількість постраждали внаслідок поперековокрижової радикулопатії (47випадків), що вимагає ретельного огляду шкідливих умов праці і трудового процесу основних професійних груп, які працюють на підприємстві, серед яких найбільш висока поширеність даної патології. Серед постраждалих з бронхо-легеневої патологією переважає діагноз ХОЗЛ токсикопиловий і пилової етіології 102 осіб. 3 вищевикладеного випливає, що у більшості постраждалих з ХОЗЛ (82 працівника, що становить 80\% з постраждалих внаслідок ХОЗЛ) мало місце істотне зниження працездатності, тобто, захворювання було діагностовано на початковій стадії. 3 цього випливає, що більшість постраждалих $102(88.70 \%)$ мають професійних захворювання, тобто для них характерно істотне зниження працездатності. Щодо гендерних особливостей захворюваності професійною патологією, то серед постраждалих переважають особи чоловічої статі $80 \%$, на жінок припадає $20 \%$.

Висновок: Гігієнічні вимоги до планувальних, будівельним заходам полягають у наступному: максимально можливе (в гарячих цехах) використання аерації, в 
необхідних випадках кондиціонування; виділення майданчиків для охолодження готових виробів або нагрітих заготовок; однорядне розташування обладнання. Оптимальною є комбінована система освітлення (загальне і місцеве) з установкою світильників безпосередньо на обладнанні. У сучасних великих спеціалізованих ковальських і штампувальних цехах на основі застосування сучасної технології нагріву, обробки металів тиском, комплексної механізації і автоматизації основних виробничих процесів практично усунуті всі шкідливі і небезпечні виробничі фактори.

Для кращого досягнення результатів слід дотримуватись гігієнічних профілактичних норм:

-проведення диспансерного спостереження та оздоровлення;

-вдосконалення лікувально-профілактичної, експертної реабілітаційної медичної допомоги постраждалим на виробництві;

-навчання адміністрації і працівників організацій (підприємств) основам медичних знань, способам збереження здоров'я на робочому місці.

\section{Список використаних джерел:}

1. Грінченко О. І., Губіна С. Л., Дрожжина Т. В., ... Слесик К. М. (2015). Харківщинознавство . Харків: Гімназія. ISBN 978-966-474-129-0.

2. Костюк, І. Ф., Капустник В. А. (2003). Професійні хвороби: Підручник. - 2-е вид., глава 13. Вилучено із http://repo.knmu.edu.ua/bitstream/123456789/580/3/Profhvoroby.pdf

Анкутова Анна Володимирівна, студентка 4 курсу 4 медичного факультету Харківський національний медичний університет, Україна

Атаі Саід Газанфар огли, студент 4 курсу 4 медичного факультету Харківський національний медичний університет, Україна

Науковий керівник: Тучкіна Марина Юріївна, кандидат медичних наук, асистент кафедри неврології №1

Харківський національний медичний університет, Украйна

\section{ФІБРОМІАЛГІЯ}

В XIX столітті лікарі описували хворобливі м'язові стани як ревматизм або м'язовий ревматизм. Пізніше, у 1904-му році, сер Вільям описав такий стан як запальний процес у сполучній тканині, та вперше представив термін фіброзит. В 1972-му році Сміт ввів сучасне розуміння фіброміалгії. В 1975 -му році за допомогою різноманітних досліджень, була підтверджена відсутність зв'язку цього захворювання з запаленням та наступного року термін фіброзит був замінений на фіброміалгію. В 1987-му році Американська медична асоціація (Journal of the American Medical Association (JAMA)) вперше визнала фіброміалгію як окреме захворювання. Вперше критерії фіброміалгії були опубліковані Американським коледжем ревматології в 1990 році.

Фіброміалгія - це розповсюджене позасуглобове захворювання невідомої етіології, яке характеризується генералізованими болями (інколи тяжкими), хворобливістю в типових точках, розповсюдженою хворобливістю м'язів, місць прикріплення сухожилків до костей, суміжних м'якотканинних структур, а також скованістю м’язів, втомлюваністю, помутнінням розуму, порушеннями сну, 
схильністю до депресії (у 75 \% хворих), вегетативними та функціональними порушеннями різного ступеню тяжкості.

Джерелом больових відчуттів може бути фіброзно-м'язова тканина будь-якої локалізації, але особливо часто уражуються ділянка потилиці, нижня частина спини, плечові суглоби, грудна клітка та стегна. Симптоми та ознаки фіброміалгії генералізовані, на відміну від локалізованих болей м'яких тканин, які часто пов'язані $з$ надлишковим навантаженням або травматизацією (міофасціальний больовий синдром). У більшості пацієнтів відмічаються симптоми подразненого кишківника, інтерстиціального циститу, мігрені або головних болей напруження. Можливі парестезії, як правило, білатеральні.

Симптоми можуть бути посилені дією стресових факторів навколишнього середовища або емоційним стресом, недостатньою кількістю сну, травмою, впливом вогкості та холоду, а також відношенням з боку лікаря, членів родини або друзів, які сприймають хворобу як вигадку. Пацієнти часто бувають напруженими, тривожними, втомленими, інколи подавленими.

\section{ЕТІОЛОГІЯ}

Маються деякі свідоцтва, що фіброміалгія є розладом больової чутливості центрального генеза. Причина фіброміалгії невідома, але іiі розвитку може сприяти порушення 4ї фази сну. До таких висновків вчені прийшли після виявлення патологічних мозкових хвиль при проведенні ЕЕГ уві сні. Також у даних пацієнтів був виявлений низький рівень гормону соматотропіну (виробляється гіпофізом у фазі глибокого сну). Аналогічні прояви спостерігаються у здорових людей при відсутності сну протягом декількох днів. Не всі спеціалісти підтримують цю теорію, однак, за даними норвежських досліджень, у жінок старше 45 років, які відмічають в себе симптоми безсоння, ризик фіброміалгії в п’ять разів вище, аніж у жінок того ж віку, які не мають проблем із засинанням.

фіброміалгія може провокуватися вірусними або іншими системними інфекціями (наприклад, хворобою Лайма), а також травмами, однак пролонгована противірусна терапія або антибіотикотерапія не призначається, адже вона неефективна.

В 2013 році спеціалістами американської біофармацевтичної компанії Integrated Tissue Dynamics (Intidyn) при підтримці Albany Medical College, було проведене дослідження, яке показало, що в пацієнтів з фіброміалгією більша, аніж в нормі, кількість чутливих нервових закінчень, розташованих в артеріоло-венозних анастомозах та судинах мікроциркуляторного русла в долонях та ступнях, які виконують функції терморегуляції та перерозподілення крові. Таким чином, м'язовий біль, слабкість та підвищена втомлюваність, які являються головними клінічними симптомами захворювання, можуть бути пов'язані з виявленними в цих судинах патологічними змінами, що призводять до порушення нормальної циркуляції крові в м’язах. Також, супутнє порушення кровопостачання головного мозку може бути причиною порушень сну та зниження когнітивної функції у більшості хворих.

Розглядаючи дані досліджень та описані клінічні прояви можна зробити висновок, що фіброміалгія $є$ комплексною проблемою, більш складною, аніж припускали спеціалісти раніше. Наявність великої кількості клінічних симптомів, які не мають в своїй основі морфологічних, біохімічних та інших порушень, дозволяє віднести фіброміалгію до категорії соматоформних порушень. На сучасному етапі вивчення даного захворювання вчені намагаються інтегрувати периферичні та центральні механізми у єдину теорію, що могла б пояснити патогенез виникаючих порушень. 


\section{ЕПІДЕМІОЛОГІЯ}

У більшості пацієнтів симптоми захворювання з'являються у віці від 30 до 55 років. У жінок фіброміалгія розвивається у 8 разів частіше, аніж у чоловіків. Близько 75-90 \% пацієнтів з фіброміалгією - жінки.

\section{ДІАГНОСТИКА}

Для встановлення діагнозу фіброміалгії немає специфічних діагностичних методів.

При фізикальному обстеженні виявляються обмежені зони м'язів (больові точки), які $\epsilon$ чутливими при пальпації. Набряку, гіперемії даних ділянок немає. Специфічних гістологічних змін м'яких тканин не виявлено.

Фіброміалгія часто супроводжується коморбідними психічними станами, такими як: депресія, тривога, обесивно- компульсивний розлад, посттравматичний стресовий розлад. Клінічно у багатьох випадках пацієнти мають негативне сприйняття себе, свого образу, тіла, страждають від низької самооцінки, мають суїцидальні тенденції. Враховуючи ці данні фіброміалгія може бути трактована як психологічний стан, а не соматичне захворювання.

Постановка діагнозу заснована на клінічних критеріях, складених Американською колегією ревматологів, які включають поєднання генералізованого болю протягом принаймні 3 міс., особливо коли він супроводжувався різними соматичними симптомами та наявність інших різних когнітивних та соматичних симптомів, таких як ті, що були перераховані вище. Попередні критерії грунтувалися на наявності чутливості при пальпації 18 специфічних больових точок. Цей критерій був виключений.

Лабораторні дослідження для виявлення інших причин симптомів пацієнта включає визначення ШОЭ, вміст С-реактивного білку, тест циклічного цитрулінованого пептиду, креатинфосфокінази, тести на наявність гіпотиреозу та гепатиту C, які можуть викликати схожі клінічні симптоми. Також необхідно провести тести для диференціювання ревматичних захворювань, т.я. фіброміалгія може бути помилково розцінена як загострення РА або СКВ.

\section{ЛІКУВАННЯ}

Оскільки фіброміалгія до кінця не вивчена, лікуванням таких пацієнтів займаються три лікаря: невролог, ревматолог та психіатр .

Медикаментозна терапія: антидепресанти, протиепілетпичні препаратипрегабалін, бензодіазепіни, снодійні засоби небензодіазепінової структури, агоністи дофамінових рецепторів, седативні, болезаспокійливі ( нестероїдні протизапальні засоби, опіоїдні анальгетики), міорелаксанти, антиоксиданти. Періодично, з метою зняття інвалідизуючої вогнищевої болі використовуються локальні ін'єкції 1-5 мл $1 \%$ розчину лідокаїну.

Немедикаментозна терапія: полегшення може бути досягнуте за допомогою регулярних вправ на розтягнення, аеробних вправ, місцевих теплових процедур та м'якого масажу м'язів. Необхідні заходи, направлені на боротьбу зі стресом (наприклад, вправи з глибоким диханням, медитація, психотерапія, аутогенне тренування). Доказана ефективність гіпербаричної кисневої терапії.

\section{Список використаних джерел :}

1. Musculoskeletal disorders- Darryl Kaelin, Terry H Oh, Peter A. C. Lim, Victoria Brander, Joseph J. Biundo, Louisiana State University Health Sciences Center, 2018

2. Wolfe F, Clauw DJ, Fitzcharles MA, et al: 2016 revisions to the 2010/2011 fibromyalgia diagnostic criteria. Semin Arthritis Rheum:319-329, 2016.

3. Myofascial pain syndrome- Noshir R. Mehta , DMD, MDS, MS, Department of Public Health and Community Service, 2019.

4. Терапия боли. Диагностика и лечение фибромиалгии- «Эффективная фармакотерапия. Неврология», 2010, № 5, с. 6-12. Д.м.н., профессор, А.Б. Данилов, Кафедра нервных болезней ФППО, Первый МГМУ им. И.М. Сеченова 


\section{МАТЕРІАЛИ МІЖНАРОДНОÏ \\ СТУДЕНТСЬКОЇ НАУКОВОЇ КОНФЕРЕНЦІЇ \\ «НАУКА, ТЕХНОЛОГІЇ, ІННОВАЦІї: ТЕНДЕНЦІЇ РОЗВИТКУ В УКРАЇНІ ТА СВІТІ»}

17 квітня 2020 року Харків, Україна

TOM 2

Українською, російською та англійською мовами

Всі матеріали пройшли оглядове рецензування

Організаційний комітет не завжди поділяє позицію авторів

За точність викладеного матеріалу відповідальність несуть автори

Підписано до друку 17.04.2020. Формат 60×84/16.

Папір офсетний. Гарнітура Arial. Цифровий друк.

Умовно-друк. арк. 4,65.

Тираж: 100 примірників.

Віддруковано з готового оригінал-макету.

Контактна інформація організаційного комітету:

21037, Україна, м. Вінниця, вул. Зодчих, 40, офріс 103

Молодіжна наукова ліга

Телесони: +38098 1948380; +380981956755

E-mail: liga@ukrlogos.in.ua

www.ukrlogos.in.ua | www.ojs.ukrlogos.in.ua

Видавець друкованих матеріалів: Друкарня ФОП Гуляєва В.М.

08700, Україна, м. Обухів, вул. Малишка, 5. E-mail: 5894939@gmail.com

Свідоцтво суб'єкта видавничої справи: ДК № 3909 від 02.11.2010р. 